Instituto de Pesquisas Energéticas e Nucleares

Autarquia Associada à Universidade de São Paulo

\title{
Desenvolvimento de condutores protônicos cerâmicos para operação de células a combustível de óxido sólido com combustíveis metano e hidrogênio
}

\author{
Olavo Rodrigues de Oliveira
}

Dissertação apresentada como parte dos requisitos para obtenção do Grau de Mestre em Ciências na Área de Tecnologia Nuclear - Materiais.

Orientador: Dr. Reginaldo Muccillo

São Paulo

2009 


\section{AGRADECIMENTOS}

Gostaria de agradecer em primeiro lugar ao Dr. Reginaldo Muccillo, pelos ensinamentos, apoio e orientação desde a iniciação científica até o presente trabalho.

À Profạ. Dra. Eliana N. S. Muccillo, pela colaboração no desenvolvimento do trabalho de pesquisa.

A Yone V. França pelas análises térmicas e por fluorescência de raios $X$.

Ao Celso V. de Moraes pelas observações no microscópio eletrônico de varredura.

Aos colegas do Laboratório de Eletrocerâmicas pelas discussões.

À Fapesp pela concessão da bolsa de mestrado (Processo 07/51631-0).

Aos meus pais, Murilo e Maria Antonia, ao meu irmão Leandro e a Adriana Aoki. 


\title{
Desenvolvimento de condutores protônicos cerâmicos para operação de células a combustível de óxido sólido com combustíveis metano e hidrogênio
}

\author{
Olavo Rodrigues de Oliveira
}

\section{Resumo}

Eletrólitos sólidos cerâmicos de zirconato de bário dopado com ítrio foram preparados por meio de mistura de óxidos de bário, de zircônio e de ítrio seguida de tratamento térmico. Foram também preparados compostos segundo uma rota alternativa, baseada na adição de óxido de bário a zircônia estabilizada com ítria. As composições preparadas foram $\mathrm{BaZr}_{0,92} \mathrm{Y}_{0,08} \mathrm{O}_{3-\delta}$ e $\mathrm{BaZr}_{0,85} \mathrm{Y}_{0,15} \mathrm{O}_{3-\delta}$. Os materiais de partida foram analisados por difração de raios $X$ (fases cristalinas) e espalhamento laser (distribuição de tamanho de partículas). Análise térmica simultânea (termogravimétrica e térmica diferencial) foi feita para o estudo do comportamento térmico durante a formação dos compostos. Pós compactados foram sinterizados e caracterizados por meio de determinação de a) densidade aparente pelo método de Arquimedes com querosene como meio líquido, b) fases cristalinas por difração de raios $\mathrm{X}$, e c) morfologia por microscopia eletrônica de varredura de superfícies de fratura. Melhor densificação foi obtida para o composto $\mathrm{BaZr}_{0,92} \mathrm{Y}_{0,08} \mathrm{O}_{3-\delta}$. Células eletroquímicas planares unitárias do tipo (Pt)/condutor protônico/catodo ( $\mathrm{Pt}$ ou $\mathrm{La}_{0,6} \mathrm{Ca}_{0,4} \mathrm{Fe}_{0,8} \mathrm{Co}_{0,2} \mathrm{O}_{3-\delta}$ ) foram montadas para avaliação de potenciais de circuito aberto na faixa de temperaturas $300-600{ }^{\circ} \mathrm{C}$, potencial sob solicitação de carga a $600^{\circ} \mathrm{C}$, ambos sob metano e hidrogênio e medidas elétricas de espectroscopia de impedância a $600{ }^{\circ} \mathrm{C}$. O composto $\mathrm{La}_{0,6} \mathrm{Ca}_{0,4} \mathrm{Fe}_{0,8} \mathrm{Co}_{0,2} \mathrm{O}_{3-\delta}$ foi preparado por mistura dos óxidos de lantânio, de ferro de cobalto e carbonato de cálcio, em seguida sinterizados. As células eletroquímicas com condutores protônicos $\mathrm{BaZr} r_{0,8} \mathrm{Y}_{0,2} \mathrm{O}_{3-\delta}$ apresentaram os maiores valores de potencial de circuito aberto e de densidade de corrente sob metano.

Palavras-chave: condutor protônico, zirconato de bário, metano. 


\title{
Development of ceramic protonic conductors for solid oxide fuel cells operation under methane and hydrogen fuels
}

\author{
Olavo Rodrigues de Oliveira
}

\begin{abstract}
Yttrium-doped barium zirconate ceramic solid electrolytes were prepared by mixing and heat treating barium, zirconium and yttrium oxides. An alternative route, based on the addition of barium to yttria-stabilized zirconia, was also followed. The compositions studied were $\mathrm{BaZr}_{0.92} \mathrm{Y}_{0.08} \mathrm{O}_{3-\delta}$ and $\mathrm{BaZr}_{0.85} \mathrm{Y}_{0.15} \mathrm{O}_{3-\delta}$. The starting materials were analyzed by X-ray diffraction (crystalline phases) and laser scattering (distribution of particle size). Simultaneous thermogravimetric and differential thermal analyses were performed for the study of the thermal behavior during the formation of the compounds. Pressed powders were sintered and characterized by determining a) apparent density by the Archimedes method with kerosene as liquid medium, b) crystalline phases by X-ray diffraction, c) morphology by scanning electron microscopy of fracture surfaces. Densification was best achieved for $\mathrm{BaZr}_{0.92} \mathrm{Y}_{0.08} \mathrm{O}_{3-\delta}$. Unitary planar electrochemical cells of the type anode (Pt)/protonic conductor/cathode (Pt or $\mathrm{La}_{0.6} \mathrm{Ca}_{0.4} \mathrm{Fe}_{0.8} \mathrm{Co}_{0.2} \mathrm{O}_{3-\delta}$ ) were assembled for evaluation of open circuit voltage (OCV) in the $300-600{ }^{\circ} \mathrm{C}$ range, current density at $600{ }^{\circ} \mathrm{C}$, both under methane and hydrogen and electrical measures of impedance spectroscopy at $600{ }^{\circ} \mathrm{C}$. The $\mathrm{La}_{0.6} \mathrm{Ca}_{0.4} \mathrm{Fe}_{0.8} \mathrm{Co}_{0.2} \mathrm{O}_{3-\delta}$ (LCFC) compound was prepared by mixing lanthanum oxide, iron oxide, cobalt oxide and calcium carbonate and sintering. The electrochemical cells with $\mathrm{BaZr}_{0.8} \mathrm{Y}_{0.2} \mathrm{O}_{3-8}$ protonic conductors showed the highest $\mathrm{OCV}$ and current density values under methane.
\end{abstract}

Keywords: protonic conductor, barium zirconate, methane. 


\section{ÍNDICE}

I. Introdução

II. Objetivos

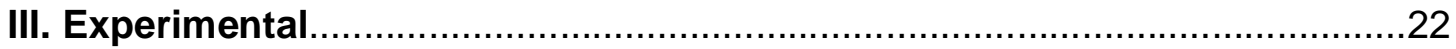

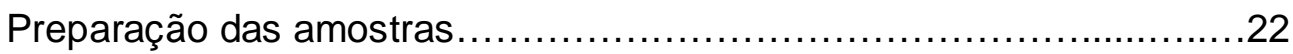

Preparação dos compactos cerâmicos .........................................23

Caracterização dos pós cerâmicos.................................................25

Caracterização dos compactos sinterizados..........................................25

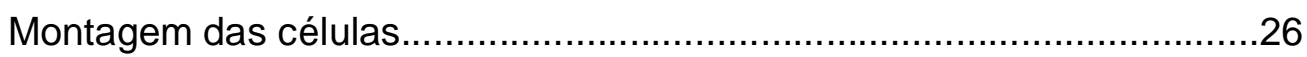

IV. Resultados

A. Materiais de partida

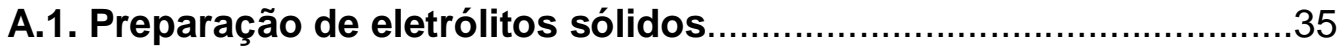

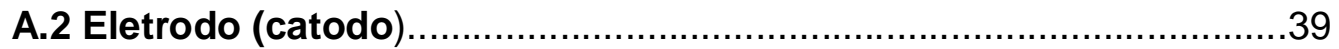

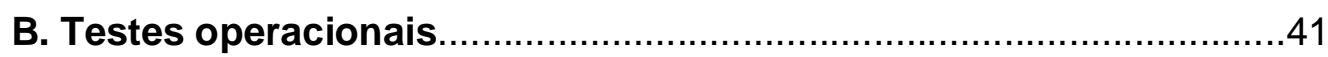

1. Célula LCFC/BaCe $e_{0,8} \mathrm{Gd}_{0,2} \mathrm{O}_{3-\delta} / \mathrm{Pt}$ e $\mathrm{Pt} / \mathrm{BaCe}_{0,8} \mathrm{Gd}_{0,2} \mathrm{O}_{3-\delta} / \mathrm{Pt} \ldots 41$

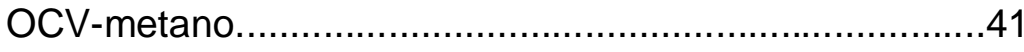

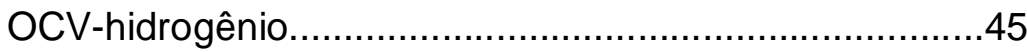

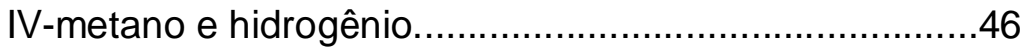

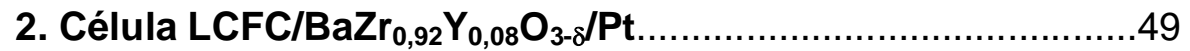

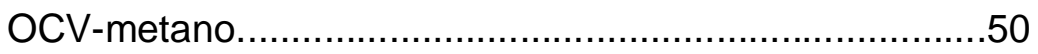

OCV-hidrogênio...........................................................

IV-metano e hidrogênio.................................................53

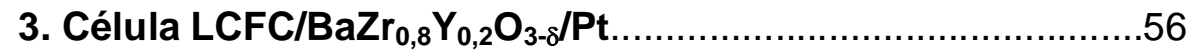

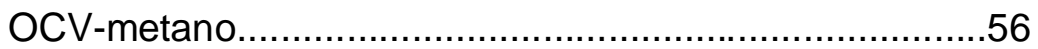

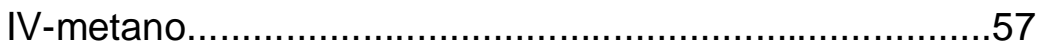

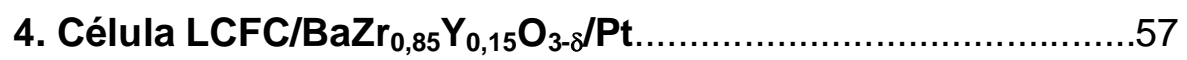

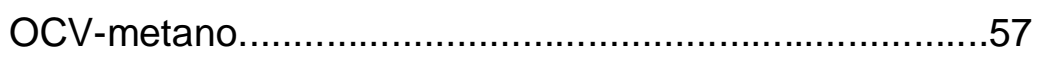

OCV-hidrogênio..........................................................

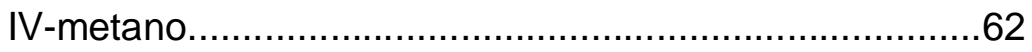

5. Espectroscopia de impedância.............................................63

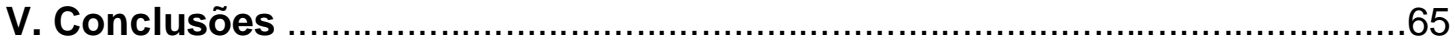

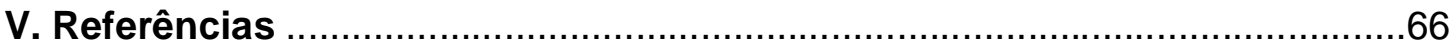




\section{Introdução}

Uma grande mudança energética pode ser iniciada na próxima década, quando o hidrogênio poderá se tornar um importante combustível para gerar energia elétrica e movimentar veículos por meio de células a combustível, substituindo aos poucos o diesel e a gasolina. A preparação desse novo cenário envolve vários institutos de pesquisa, todas as matrizes das montadoras da indústria automobilística, e as empresas petrolíferas e energéticas de todo o planeta. Motivos para o uso do hidrogênio não faltam: os preços do barril de petróleo oscilam no mercado internacional e essa commodity não é distribuída igualmente entre os países, além da necessidade de diminuição da poluição atmosférica. O uso desse gás formado por dois átomos de hidrogênio ajuda a diminuir a presença de outro gás, o carbônico $\left(\mathrm{CO}_{2}\right)$, produzido pela queima dos combustíveis fósseis oriundos do petróleo, o principal causador do efeito estufa, fenômeno que pode aumentar a temperatura média da Terra e promover diversos problemas ambientais e de saúde pública [1].

\section{Células a combustível}

Células a combustível são conversores diretos de energia química em elétrica e térmica de funcionamento contínuo (diferentemente das baterias), que produzem corrente contínua pela combustão eletroquímica de um combustível, geralmente hidrogênio [2]. Assim, o hidrogênio é oxidado a prótons no anodo, liberando elétrons, segundo a reação:

$\mathrm{H}_{2} \rightarrow 2 \mathrm{H}^{+}+2 \mathrm{e}^{-}$

No eletrodo oposto, o catodo, tem-se a reação:

$2 \mathrm{H}^{+}+2 \mathrm{e}^{-}+1 / 2 \mathrm{O}_{2} \rightarrow \mathrm{H}_{2} \mathrm{O}$

A reação global produz água e calor (exotérmica): 
Os eletrodos são condutores eletrônicos permeáveis aos gases reagentes, separados um do outro por um eletrólito sólido inorgânico condutor iônico (ou protônico).

Células unitárias experimentais, isto é, compostas de um conjunto anodo/ eletrólito/ catodo, apresentam um potencial de circuito aberto (OCV - Open Circuit Voltage) de 1,0 a 1,35 V sob $\mathrm{H}_{2}$. Para se obter potenciais práticos de 200 a $300 \mathrm{~V}$ é necessário o empilhamento em série de várias células unitárias [3]. Uma das vantagens inerentes às células a combustível é a sua eficiência relativa ao combustível. A eficiência teórica máxima $\eta$ de qualquer processo de produção de energia eletroquímica é obtida pelo quociente entre a energia livre de Gibbs $(\Delta \mathrm{G})$ e a entalpia total $(\Delta \mathrm{H})$, ou seja, a parte da energia total dos reagentes que pode ser convertida em energia elétrica:

$$
\eta=\Delta \mathrm{G} / \Delta \mathrm{H}
$$

A eficiência teórica eletroquímica diminui de 86 a $70 \%$ na faixa de temperaturas de 100 a $1000^{\circ} \mathrm{C}$. A eficiência de Carnot, por sua vez, aumenta de 0 a $70 \%$ na mesma faixa de temperaturas e somente a temperaturas superiores a $1000{ }^{\circ} \mathrm{C}$ é maior que a eficiência teórica eletroquímica [4]. Portanto, células a combustível a hidrogênio apresentam uma eficiência teórica significativamente maior do que máquinas de Carnot, principalmente a baixas temperaturas.

As reações eletródicas das células a combustível envolvem, de uma maneira geral, a ruptura das ligações químicas entre dois átomos de hidrogênio e de oxigênio. A ruptura das moléculas diatômicas $\mathrm{H}_{2}$ e $\mathrm{O}_{2}$ requer uma energia de ativação da mesma ordem de grandeza de suas energias de formação, quando as reações são homogêneas e ocorrem em fase gasosa [5]. Em células a combustível, entretanto, ambas as reações são heterogêneas e ocorrem na interface eletrodo/eletrólito, sendo catalisadas na superfície do eletrodo. 
No caso de uso de metano como combustível por meio da oxidação parcial, as reações envolvidas são descritas a seguir:

$$
\begin{aligned}
& \mathrm{CH}_{4}+1 / 2 \mathrm{O}_{2} \rightarrow \mathrm{CO}+2 \mathrm{H}_{2} \quad \text { anodo } \\
& 2 \mathrm{H}_{2} \rightarrow 4 \mathrm{H}^{+}+4 \mathrm{e}^{-} \\
& \mathrm{O}_{2}+4 \mathrm{H}^{+}+4 \mathrm{e}^{-} \rightarrow 2 \mathrm{H}_{2} \mathrm{O} \text { catodo }
\end{aligned}
$$

O metano é um hidrocarboneto gasoso formado pela decomposição da matéria orgânica e pode ser classificado como um recurso renovável. Hoje no Brasil a maior parte desse gás tem origem no gás natural e o metano é utilizado para a produção de gás de síntese. Além disso, o metano é mais uma alternativa de combustível para células a combustível de óxido sólido com eletrólitos condutores protônicos, já que o seu craqueamento ocorre na faixa de temperatura de operação da célula $\left(300-600^{\circ} \mathrm{C}\right)$.

\section{Principais métodos para producão de biogás}

A Figura 1 mostra o funcionamento de um dreno vertical para queima do gás excedente (a) e o sistema de captação do gás por um dreno vertical adaptado.
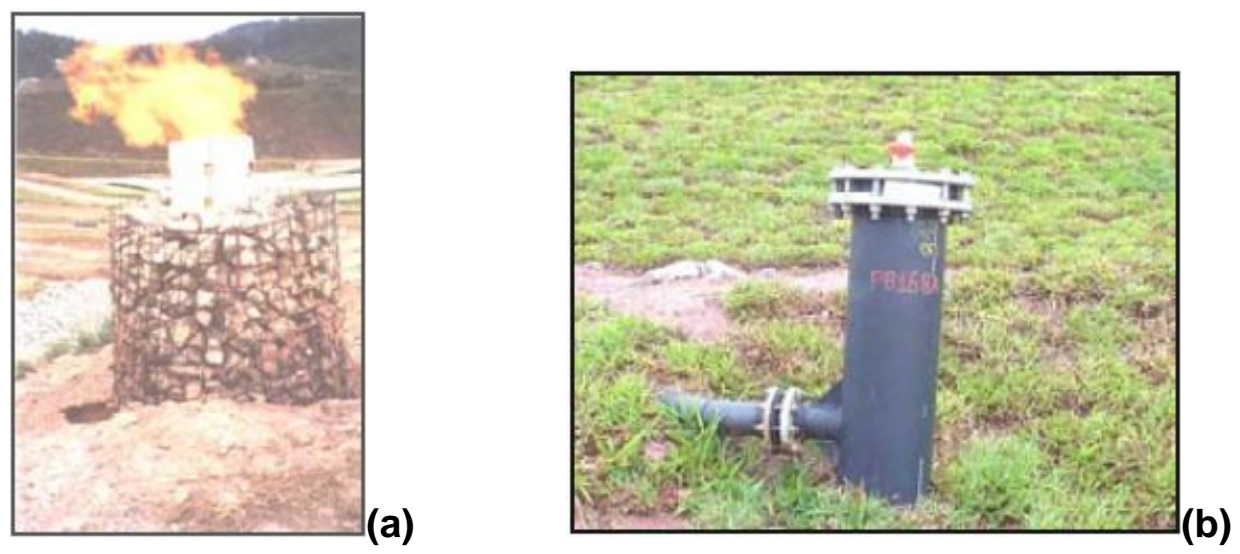

Figura 1: Dreno vertical para queima do gás excedente (a) e dreno adaptado para captação do biogás (b). 
Este sistema de dreno adaptado faz parte do aproveitamento do biogás produzido pelo aterro Bandeirantes (S. Paulo, SP). Em um aterro sanitário pode haver vários pontos de captação do gás através de drenos que seguem por tubulação até uma unidade de agrupamento [6].

A Figura 2 mostra uma planta de biogás produzido por meio da decomposição anaeróbia de matéria orgânica.

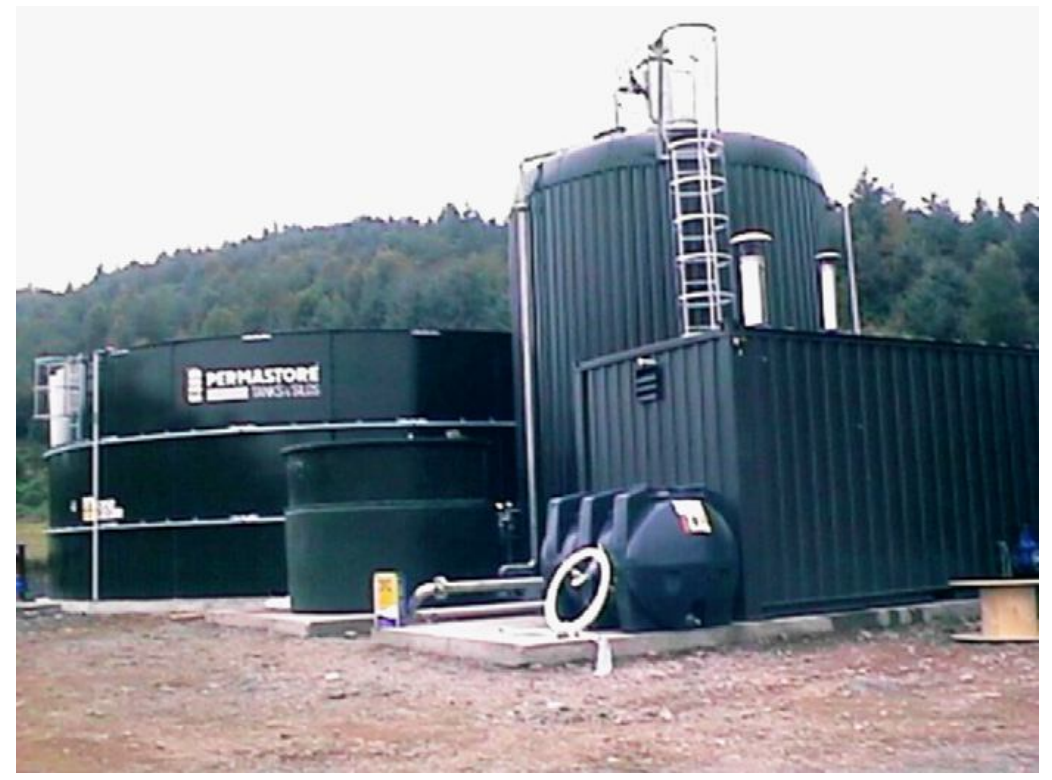

Figura 2: Planta de biogás (digestor anaeróbio, tanque de armazenamento de gás e tanque de armazenamento de resíduos).

A digestão anaeróbia é um processo natural que ocorre na ausência de oxigênio. Envolve a decomposição de resíduos orgânicos por microrganismos que produzem energia, biogás e um nutriente que é composto de um líquido e um sólido material fibroso.

O biogás produzido consiste basicamente de $60 \%$ de metano e o restante de dióxido de carbono com pequenas quantidades de ácido sulfídrico e amônia [7].

A Figura 3 mostra as duas principais formas nas quais o gás natural é encontrado nos reservatórios naturais. 

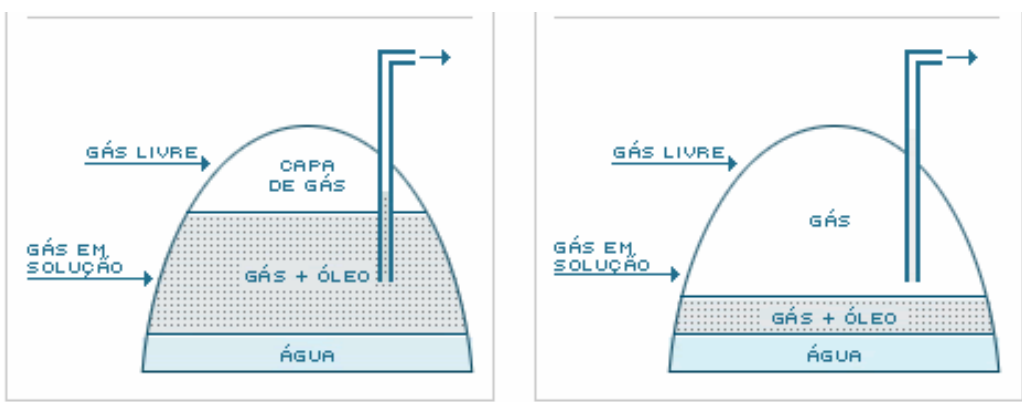

Figura 3: Reservatórios produtores de óleo e gás natural.

O gás natural é uma mistura de hidrocarbonetos gasosos cuja composição abrange do metano $\left(\mathrm{CH}_{4}\right)$ ao hexano $\left(\mathrm{C}_{6} \mathrm{H}_{6}\right)$, sendo o metano o principal componente. Apresenta também pequenas quantidades de componentes diluentes, como nitrogênio e vapor d’água, e contaminantes (gás sulfídrico e dióxido de carbono).

O gás natural é mais leve do que 0 ar (densidade $0,6 \mathrm{~g} / \mathrm{cm}^{3}$ ), não tem cheiro e sua combustão fornece de 8.000 a $10.000 \mathrm{kcal} / \mathrm{m}^{3}$. Ocorre na natureza em solução no óleo (gás associado) ou no estado livre (gás não associado). O gás associado é aquele que, no reservatório, está dissolvido no óleo ou sob a forma de capa de gás. As maiores ocorrências de gás natural no mundo são de gás não associado [8].

Esses sistemas para captação de biogás são importantes para a redução das emissões por atividades antrópicas, pois o metano é um gás estufa com um potencial 21 vezes maior para absorver radiação infravermelha e irradiar parte da energia absorvida do que o dióxido de carbono, por exemplo, devido à geometria da molécula (tetraédrica); o metano também permanece por aproximadamente 10 anos na atmosfera e sua concentração vem aumentando gradativamente, segundo o relatório elaborado em 2007 pelo IPCC (Intergovernmental Panel on Climate Change).

\section{Tipos de células a combustível}

A Tabela 1 mostra as principais células a combustível, o eletrólito e o portador de carga, a faixa de temperatura de operação, as vantagens, as desvantagens e as aplicações. 
Tabela 1 - Principais tipos de células a combustível [3].

\begin{tabular}{|c|c|c|c|c|c|}
\hline Tipo & $\begin{array}{c}\text { Eletrólito } \\
\text { (portador } \\
\text { de } \\
\text { carga) }\end{array}$ & $\begin{array}{c}\text { Faixa de } \\
\text { temperatura } \\
\left({ }^{\circ} \mathrm{C}\right)\end{array}$ & Vantagens & Desvantagens & Aplicação \\
\hline $\begin{array}{l}\text { Alcalina } \\
\text { (AFC) }\end{array}$ & $\begin{array}{l}\mathrm{KOH} \\
\left(\mathrm{OH}^{-}\right)\end{array}$ & $60-90$ & $\begin{array}{l}\text { - Alta } \\
\text { eficiência } \\
\text { (83\% da } \\
\text { teórica) }\end{array}$ & $\begin{array}{l}\text { - Sensível a } \mathrm{CO}_{2} \\
\text { - Gases ultra puros, sem } \\
\text { reforma do combustível }\end{array}$ & $\begin{array}{l}\text { - Espaçonaves } \\
\text { - Aplicações militares }\end{array}$ \\
\hline $\begin{array}{l}\text { Membrana } \\
\text { (PEMFC) }\end{array}$ & $\begin{array}{c}\text { Polímero } \\
\text { Nafion }{ }^{\circledR} \\
\left(\mathrm{H}_{3} \mathrm{O}^{+}\right)\end{array}$ & $80-90$ & $\begin{array}{l}\text { - Alta } \\
\text { densidade } \\
\text { de corrente } \\
\text { - Operação } \\
\text { flexível }\end{array}$ & $\begin{array}{l}\text { - Custo da membrana, } \\
\text { Potência e Eficiência } \\
\text { - Contaminação do } \\
\text { catalisador com Co }\end{array}$ & $\begin{array}{l}\text { - Veículos } \\
\text { automotores e } \\
\text { catalisadores, } \\
\text { espaçonaves } \\
\text { - Mobilidade }\end{array}$ \\
\hline $\begin{array}{l}\text { Ácido } \\
\text { fosfórico } \\
\text { (PAFC) }\end{array}$ & $\begin{array}{l}\mathrm{H}_{3} \mathrm{PO}_{3} \\
\left(\mathrm{H}_{3} \mathrm{O}^{+}\right)\end{array}$ & $160-200$ & $\begin{array}{l}\text { - Maior } \\
\text { desenvolvi- } \\
\text { mento } \\
\text { tecnológico }\end{array}$ & $\begin{array}{l}\text { - Controle da porosidade } \\
\text { do eletrodo } \\
\text { - Sensibilidade a Co } \\
\text { - Eficiência limitada pela } \\
\text { corrosão }\end{array}$ & $\begin{array}{l}\text { - Unidades } \\
\text { estacionárias } \\
\text { - Cogeração } \\
\text { eletricidade/calor }\end{array}$ \\
\hline $\begin{array}{l}\text { Carbonato } \\
\text { fundido } \\
\text { (MCFC) }\end{array}$ & $\begin{array}{l}\text { Carbonatos } \\
\text { fundidos } \\
\left(\mathrm{CO}_{3}{ }^{2-}\right)\end{array}$ & $650-700$ & $\begin{array}{l}\text {-Tolerância } \\
\text { a } \mathrm{CO} / \mathrm{CO}_{2} \\
\text { - Eletrodos } \\
\text { à base de } \mathrm{Ni}\end{array}$ & $\begin{array}{l}\text { - Problema de materiais } \\
\text { - Necessidade da } \\
\text { reciclagem de } \mathrm{CO}_{2} \\
\text { - Interface trifásica de } \\
\text { difícil controle }\end{array}$ & $\begin{array}{l}\text { - Unidades } \\
\text { estacionárias } \\
\text { - Cogeração } \\
\text { eletricidade/calor }\end{array}$ \\
\hline $\begin{array}{l}\text { Óxido } \\
\text { Sólido } \\
\text { (SOFC) }\end{array}$ & $\begin{array}{l}\mathrm{ZrO}_{2} \\
\left(\mathrm{O}^{2-}\right)\end{array}$ & $800-900$ & $\begin{array}{l}\text { - Alta } \\
\text { eficiência } \\
\text { (cinética } \\
\text { favorável) } \\
\text { - Reforma } \\
\text { interna }\end{array}$ & $\begin{array}{l}\text { - Problemas de materiais } \\
\text { - Expansão térmica } \\
\text { - Necessidade de pré- } \\
\text { reforma }\end{array}$ & $\begin{array}{l}\text { - Unidades } \\
\text { estacionárias de } 10 \text { a } \\
\text { algumas centenas de } \\
\text { kW } \\
\text { - Cogeração } \\
\text { eletricidade/calor }\end{array}$ \\
\hline
\end{tabular}

\section{Células a combustível de óxido sólido - SOFC}

Há vários tipos de células a combustível, classificadas de acordo com o material usado como eletrólito. Aqui trataremos de células a combustível de óxido sólido.

As células a combustível de óxido sólido (Solid Oxide Fuel Cell - SOFC) operam na faixa de 600 a $100{ }^{\circ} \mathrm{C}$. Não há necessidade do uso de metais nobres 
como catalisadores. Possuem maiores valores de eficiência teórica de conversão e têm uma alta capacidade de co-geração eletricidade/calor. A elevada temperatura de operação favorece a cinética das reações eletródicas e permite a reforma de vários tipos de combustível para produção de hidrogênio no próprio corpo da célula. A principal aplicação desse tipo de célula é a geração de energia em unidades estacionárias [9].

Várias configurações de células a combustível de óxido sólido têm sido colocadas em operação em escala laboratorial e pré-comercial. As mais comuns são as de conceito tubular e planar [9].

As células a combustível podem ainda ser classificadas pelo seu tipo de configuração, podendo ser do tipo bi-câmara ou monocâmara. As células a combustível de óxido sólido convencionais consistem de duas câmaras separadas por um eletrólito impermeável a gases, sendo que cada uma delas contém um dos eletrodos (catodo ou anodo). O princípio de funcionamento dessas células é baseado na alimentação separada de combustível e ar para o anodo e o catodo, respectivamente. Outra configuração de células a combustível de óxido sólido, que recentemente voltou a ser estudada, consiste de somente uma câmara, onde o anodo e o catodo são expostos à mesma mistura de combustível e ar. Nestas células a combustível, o anodo tem uma alta atividade catalítica para oxidação do combustível enquanto que o catodo tem maior atividade eletrocatalítica para redução do oxigênio, resultando assim em uma força eletromotriz entre os dois eletrodos [10-21].

Basicamente três são os tipos de eletrólitos sólidos atualmente utilizados em pesquisa de células a combustível de óxido sólido: $\mathrm{ZrO}_{2}: \mathrm{Y}_{2} \mathrm{O}_{3}, \mathrm{CeO}_{2}: \mathrm{Gd}_{2} \mathrm{O}_{3}$ (ou $\mathrm{Sm}_{2} \mathrm{O}_{3}$ ) e $\mathrm{BaCe}_{0,8} \mathrm{Gd}_{0,2} \mathrm{O}_{3-\delta}\left(\mathrm{ou} \mathrm{BaCe}_{0,8} \mathrm{Y}_{0,2} \mathrm{O}_{3-\delta}\right.$ ). Essas composições são as que apresentam o maior valor de condutividade elétrica a uma mesma temperatura para os teores de dopantes (8 mol\% $\mathrm{Y}_{2} \mathrm{O}_{3}$ em $\mathrm{ZrO}_{2}, 20 \mathrm{~mol}_{\%} \mathrm{Gd}_{2} \mathrm{O}_{3}$ em CeO 2 e 10 mol\% $\mathrm{Gd}_{2} \mathrm{O}_{3}$ em $\left.\mathrm{BaCeO}_{3}\right)$.

Células a combustível de óxido sólido de temperatura-intermediária têm sido objeto de pesquisas $[22,23]$ para reduzir a temperatura de operação das SOFC, seja adaptando novos eletrólitos com alta condutividade iônica ou pela redução da espessura do eletrólito, ou ambos [24-26]. Grande parte do desenvolvimento recente mostra que eletrólitos sólidos com estrutura perovskita, tais como cerato de bário dopado, são promissores para operação em 
temperaturas moderadas devido a sua boa condução protônica em atmosfera de hidrogênio [26, 27]. O uso de condutores protônicos como eletrólito em SOFC apresenta algumas vantagens, se comparados com os condutores iônicos. Os condutores protônicos, ao contrário de um condutor iônico, formam água no cátodo. Isso significa que no ânodo o combustível permanece puro e não necessita de recirculação. Além disso, o cerato de bário dopado tem alta condutividade protônica em uma ampla faixa de temperatura $\left(400-800{ }^{\circ} \mathrm{C}\right)$ e sua energia de ativação térmica para a condução é inferior à dos condutores iônicos [28].

\section{Eletrólito sólido condutor iônico}

Os clássicos condutores iônicos, zircônia estabilizada e céria dopada, apresentam estrutura cúbica fluorita. A fim de introduzir vacâncias móveis de oxigênio no composto e, no caso da zircônia, para estabilizar a estrutura cúbica, são adicionados dopantes trivalentes ou divalentes. A reação de incorporação pode, por um típico dopante trivalente, M, ser escrita segundo a equação:

$$
M_{2} O_{3} \underset{Z r O_{2}}{\longrightarrow} 2 M{ }_{Z r}^{\prime}+3 O_{o}^{*}+v \ddot{o}
$$

Uma vacância de oxigênio é criada para cada dois átomos de metal incorporados. No entanto, a condutividade da zircônia e da céria aumenta com o aumento da concentração de dopante até um máximo, diminuindo em seguida. $\mathrm{Da}$ mesma forma, a condutividade aumenta e depois diminui em todos os eletrólitos sólidos dopados com íons de terras raras, do Yb ao La. A zircônia estabilizada com escândia apresenta a mais elevada condutividade iônica, mas ítria é normalmente utilizada principalmente por causa do custo. Com ítrio como dopante, a maior condutividade da zircônia é obtida com 8 mol\%. No caso de Sm [29] e Gd [30] na céria, os melhores valores de condutividade são obtidos com uma concentração de 10-20\%. A forte dependência do tipo e da concentração de dopante na condutividade iônica foi explicada pelas distorções introduzidas pelo dopante [31].

A condutividade iônica da céria é aproximadamente uma ordem de grandeza maior do que a da zircônia estabilizada, para o mesmo teor de dopante à mesma temperatura. Isso é devido em parte ao maior raio iônico do $\mathrm{Ce}^{4+}(0,87 \AA)$ 
do que do $\mathrm{Zr}^{4+}(0,72 \AA)$, que produz uma estrutura mais aberta, através da qual os íons $\mathrm{O}^{2-}$ podem migrar. A céria dopada com íons de terras raras apresenta $\mathrm{O}$ problema da condutividade eletrônica, mesmo tendo condutividade iônica maior que a da zircônia estabilizada com ítria [32, 33].

Condutores iônicos com estrutura perovskita têm sido reportados na literatura há vários anos, mas só recentemente foram descobertas as composições que apresentam condutividade elétrica suficiente para aplicação em células a combustível. Os condutores de íons oxigênio propostos para utilização em células a combustível podem ser classificados por meio da estrutura cristalina [34]: óxidos com estrutura do tipo fluorita (a base de zircônia, céria ou $\delta-\mathrm{Bi}_{2} \mathrm{O}_{3}$ ), óxidos com estrutura perovskita $\mathrm{ABO}_{3}$ ( $\mathrm{A}, \mathrm{B}$ : cátions) $\left(\mathrm{LaGaO}_{3}\right.$ dopado com $\mathrm{Ca}, \mathrm{Sr}$ ou $\mathrm{Mg}$, $\mathrm{LaAlO}_{3}$ dopado com $\mathrm{Ca}$ e titanato de cálcio dopado com alumínio), óxidos com estrutura Aurivillius (BIMEVOX, óxidos à base de bismuto), óxidos com estrutura relacionada à estrutura fluorita, como os compostos com estrutura do tipo pirocloro $\left(\mathrm{A}_{2} \mathrm{~B}_{2} \mathrm{O}_{7}, \mathrm{~A}\right.$ : metal terra rara, $\mathrm{B}$ : cátion, $\left.\mathrm{Gd}_{2} \mathrm{Ti}_{2} \mathrm{O}_{7}\right)$.

A Figura 4 mostra um esquema de uma célula a combustível de óxido sólido condutora de íons $\mathrm{O}^{2-}$ (anodo/eletrólito/catodo), as reações do agente oxidante no catodo e o redutor no anodo e um dispositivo externo para captação dos elétrons.

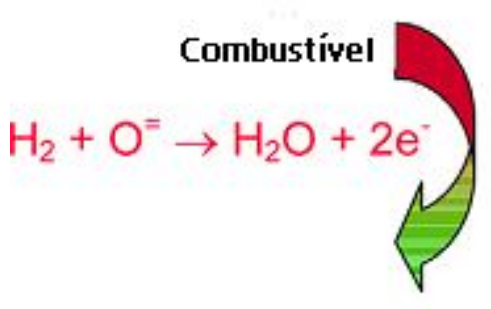

Subproduto

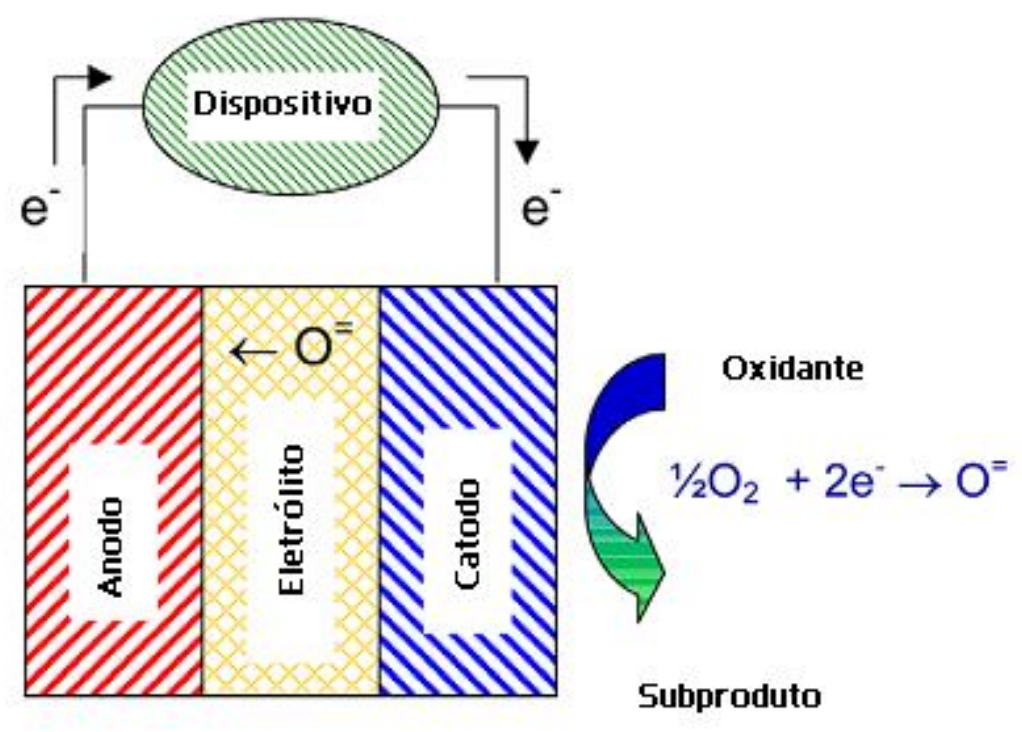

Figura 4: Esquema de funcionamento de uma célula a combustível com condutor de íons oxigênio [35]. 


\section{Eletrólito sólido condutor protônico}

Quando óxidos com estrutura perovskita, de fórmula geral $\mathrm{ABO}_{3}$, são dopados com cátions de valência menor, estes substituem parcialmente os cátions do sítio B, formando vacâncias de oxigênio [36]. Em atmosferas com presença de hidrogênio, este reage com as vacâncias para formar defeitos protônicos, íons hidroxilas [37]. As espécies $\mathrm{H}^{+}$destas hidroxilas são propostas como as responsáveis pela condução protônica no eletrólito. O mecanismo de condução elétrica ainda é tema de discussão. $O$ mais aceito mecanismo de condução protônica é o de Grotthus, que envolve a transferência de prótons entre $\mathrm{OH}^{-}$e $\mathrm{O}^{2-}$ adjacentes e reorientação da hidroxila [38]. A reação de incorporação do dopante normalmente ocorre assumindo a equação 8 .

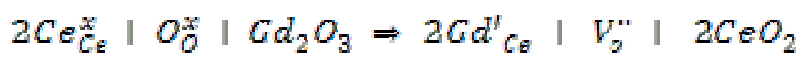

A exposição posterior dos materiais a atmosferas úmidas leva à incorporação de prótons, como descrito na equação (9)

$$
H_{2} O(\text { gas })+V_{n}^{*}+U_{n} \Rightarrow 20 H_{n} .
$$

Os prótons introduzidos dessa forma não são geralmente vinculados a um determinado íon oxigênio, mas são livres para migrar de um íon para o próximo. Essa migração resulta em uma alta condutividade protônica (maior do que $10^{-2}$ $\mathrm{S} / \mathrm{cm}$ a $500{ }^{\circ} \mathrm{C}$ ) observada nestes óxidos. $\mathrm{O}$ transporte de prótons domina $\mathrm{O}$ transporte elétrico global a temperaturas de aproximadamente $600{ }^{\circ} \mathrm{C}$; o número de transferência de prótons do $\mathrm{BaCe}_{0,95} \mathrm{Sm}_{0,05} \mathrm{O}_{3}$, por exemplo, é $\sim 0,85$ nessa temperatura [39]. Em temperaturas mais elevadas, tanto o transporte de íons quanto de elétrons tornam-se significativos.

Em perovskitas $\mathrm{A}^{2+} \mathrm{B}^{4+} \mathrm{O}_{3}$ existe a possibilidade de que a dopagem por íons trivalentes possa ocupar ambos os sítios catiônicos, e não apenas o sítio $B^{4+}[40]$. A conseqüência da incorporação parcial do dopante no sítio $A^{2+}$ é que resultará em menor teor de vacâncias de oxigênio do que previsto. $O$ efeito é agravado pela alta 
temperatura, que pode induzir a evaporação de $\mathrm{BaO}$. Em comparação com os ceratos $\left(\mathrm{BaCeO}_{3}\right.$ e $\left.\mathrm{SrCeO}_{3}\right)$, o zirconato de bário apresenta alta condutividade elétrica e excelente estabilidade química sob $\mathrm{CO}_{2}$. No entanto, a fabricação de eletrólitos densos destes materiais continua a ser um desafio. A alta condutividade dos contornos de grão do $\mathrm{BaZrO}_{3}$ não foi compreendida por vários anos, como conseqüência da natureza refratária do material, o que resulta em amostras com grãos finos e, portanto, com alta resistência total de contorno de grão [41, 42]. A baixa reatividade dos ceratos a $\mathrm{CO}_{2}$ e a dificuldade de fabricação de eletrólitos densos de zirconato, faz com que poucas células a combustível tenham sido construídas e caracterizadas. Os principais trabalhos de pesquisa são para comprovar o princípio, com Pt como eletrodo [43]. A Figura 5 mostra uma célula a combustível de óxido sólido protônica, as reações do oxidante no catodo e do redutor no anodo, a transferência de prótons através do eletrólito e os elétrons captados por um circuito externo.

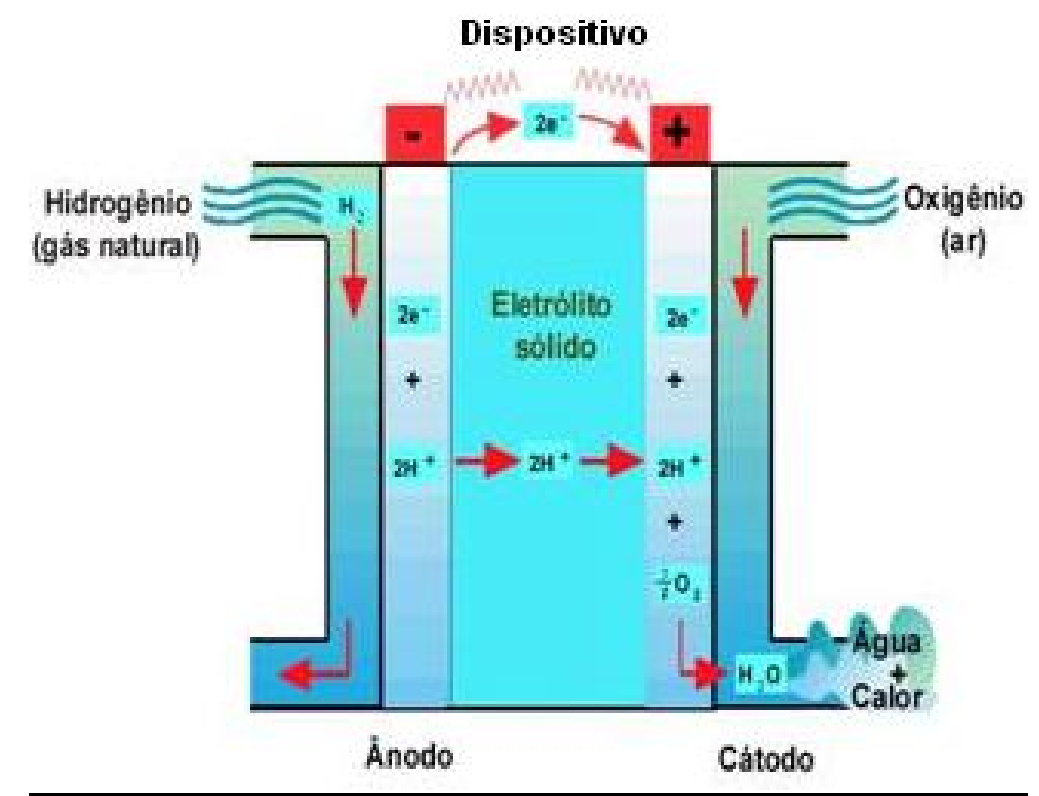

Figura 5: Esquema de condução elétrica em uma SOFC com condutor protônico [44]. 


\section{Zirconato de bário vs cerato de bário}

Cerato de bário e zirconato de bário foram estudados devido ao grande interesse na possível aplicação como sólido condutor protônico. Eletrólitos de cerato de bário sinterizados provaram serem quimicamente instáveis na presença de $\mathrm{CO}_{2}$, ou atmosferas contendo $\mathrm{SO}_{2}$ abaixo de $600{ }^{\circ} \mathrm{C}$, e apresentam baixa resistência mecânica para aplicações práticas [45, 46]. Por outro lado, o zirconato de bário sinterizado possui em geral melhor estabilidade química e mecânica do que o cerato de bário, mas menor valor de condutividade protônica. Cerâmicas de zirconato dopadas, na qual os cátions trivalentes substituem zircônio, são condutores protônicos puros em atmosfera de hidrogênio a altas temperaturas $\left(600-1000{ }^{\circ} \mathrm{C}\right)$ [42, 47]. Entretanto os valores reportados de condutividade protônica variam em mais de uma ordem de grandeza. Ao mesmo tempo, a condutividade eletrônica em ceratos de bário é relativamente elevada sob condições redutoras, enquanto que é insignificante nos zirconatos de bário [48]. Alguns pesquisadores têm salientado a necessidade de um condutor protônico sólido que combine maior estabilidade química do zirconato e a melhor condutividade elétrica do cerato. Uma solução foi proposta para a gradual substituição do Ce pelo Zr no cerato de bário [49-51]. Uma forma importante de melhorar as propriedades elétricas do zirconato de bário seria a redução da resistência elétrica do contorno de grão [52].

\section{Zirconato de bário}

$\mathrm{O}$ zirconato de bário de estrutura perovskita, $\mathrm{BaZrO}_{3}$, é um material refratário bem conhecido com elevado ponto de fusão $\left(2600^{\circ} \mathrm{C}\right)$, baixo coeficiente de expansão térmica, baixa condutividade térmica, boas propriedades mecânicas, estabilidade térmica, e baixa reatividade química com relação a compostos corrosivos [53]. O zirconato de bário é um bom candidato para muitas aplicações estruturais como cadinho para síntese de supercondutores cerâmicos de alta temperatura crítica, substrato para deposição de filmes finos, revestimentos térmicos na indústria aeroespacial [54, 55]. 
Soluções sólidas baseadas em zirconato de bário tornam-se condutores iônicos e/ou eletrônicos e são candidatos potenciais para inúmeros tipos de aplicação na área de eletrocerâmicas. O zirconato de bário dopado com cátions trivalentes é conhecido por absorver prótons na rede cristalina e atuar como condutor protônico em eletrolizadores a vapor, sensores de umidade, bombas de hidrogênio e, particularmente em SOFC [46, 47, 56-58]. A Figura 6 mostra a estrutura cúbica de tipo perovskita do zirconato de bário.

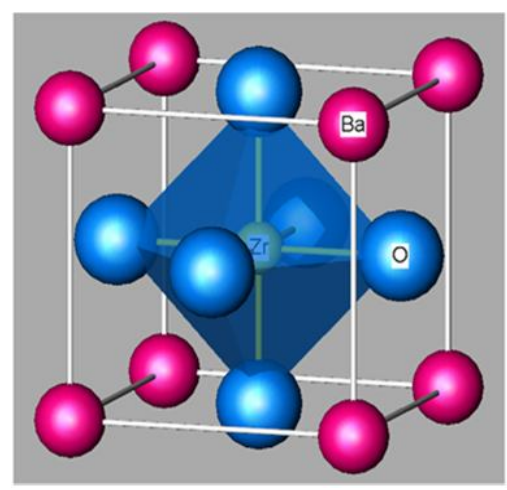

Figura 6: Estrutura cúbica do tipo perovskita do zirconato de bário [35].

Um método tradicional de síntese do zirconato de bário consiste na reação de estado sólido em altas temperaturas, geralmente entre zircônia e carbonato de bário, precedido pela homogeneização do pó e a redução dos tamanhos de partícula. Os pós preparados dessa forma apresentam vários inconvenientes como falta de reprodutibilidade do processo, tamanho relativamente grande de partícula, ampla distribuição granulométrica, forte aglomeração, e não homogeneidade química. Para superar essas dificuldades de processamento, métodos químicos são cada vez mais importantes na síntese do zirconato de bário. Nestes métodos, o pó é geralmente obtido após uma decomposição de diferentes precursores a baixas temperaturas [59].

O zirconato de bário é também usado como sensor de umidade. Muitos exemplos de sensores de umidade baseados em adsorção superficial de água ou vapor de água foram relatados [60-63], mas muitas vezes não apresentam seletividade para $\mathrm{NO}_{x}$ e $\mathrm{O}_{2}$ [64-67]. 
A alta resistividade dos contornos de grão do $\mathrm{BaZr}_{1-\mathrm{X}} \mathrm{Y}_{\times} \mathrm{O}_{3-\delta}(\mathrm{x}=0,1$ e 0,2$)$ sinterizado também limita a aplicação desses materiais, embora possa ser melhorada por meio da introdução de cério no sítio B [68].

Cerâmicas de zirconato de bário foram densificadas por sinterização a alta temperatura $\left(1700^{\circ} \mathrm{C}\right)[42,53]$. Foi também verificado recentemente que a adição de $\mathrm{ZnO}$ pode melhorar a densificação do zirconato de bário [69, 70]. Um efeito semelhante também foi mostrado, atribuindo ao $\mathrm{ZnO}$ a ação de aditivo de sinterização. Neste estudo, a condutividade do $\mathrm{BaZr}_{0.85} \mathrm{Y}_{0.15} \mathrm{O}_{3-\delta}$ foi investigada em diferentes atmosferas e o potencial de circuito aberto da célula eletroquímica, $1 \mathrm{~V}$, foi obtido com combustível $\mathrm{H}_{2} / \mathrm{ar}$ [71].

\section{Flexibilidade de combustível em condutores protônicos}

É comumente aceito que SOFCs também podem operar com metano e outros hidrocarbonetos. Para isso, diversas configurações foram propostas [72, 73]. A Figura 7 mostra o esquema de uma SOFC protônica operando com metano.

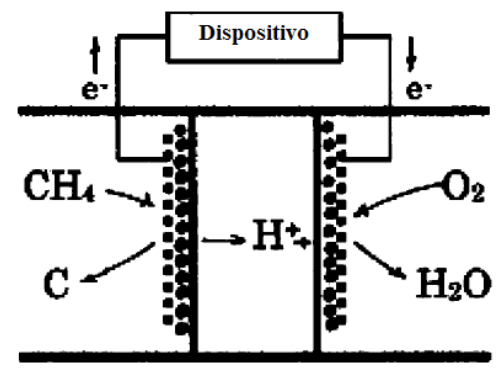

Figura 7: Esquema de uma célula a combustível de óxido sólido, protônica, operando com metano [72].

Nesse caso, os prótons devem ser produzidos diretamente no anodo antes de serem absorvidos. Nessa hipótese, o anodo é considerado um reator químico. Reações produzindo $\mathrm{H}_{2}$ a partir de $\mathrm{CH}_{4}$ são favorecidas a altas temperaturas, quando o eletrólito apresenta condutividade protônica e iônica. Entre 500 e $600{ }^{\circ} \mathrm{C}$, que é a faixa de temperatura com pura condutividade protônica, devido aos baixos valores das constantes termodinâmicas $(\Delta \mathrm{G}, \Delta \mathrm{H})$, espera-se que apenas pequenas 
quantidades de $\mathrm{H}_{2}$ sejam formadas pela reforma do vapor. Experimentos com uma célula ar/Pt/BaCe ${ }_{0,9} \mathrm{Y}_{0,1} \mathrm{O}_{3-\delta} / \mathrm{Pt} / \mathrm{H}_{2}$ a $750{ }^{\circ} \mathrm{C}$ tendem a confirmar esta análise [73]. Sob hidrogênio úmido, o potencial inicial é igual ao potencial esperado segundo a equação de Nernst, enquanto que com CO úmido, não excede 0,6 V, indicando a baixa quantidade de $\mathrm{H}_{2}$ formada no anodo. Sem adição significativa de água no anodo, a permeação do catodo para o anodo de qualquer teor de vapor será insuficiente para permitir a reforma principal de $\mathrm{CH}_{4}$ e produzir altas densidades de correntes.

É possível que SOFC protônicas operando sob combustível hidrocarboneto seco não tenham bom desempenho devido à falta de hidrogênio no anodo e à alta degradação por causa da formação de carbono [74]. 


\section{Objetivos}

Os objetivos específicos desse trabalho são:

- Preparar eletrólitos sólidos condutores protônicos dos tipos $\mathrm{BaZr}_{0,92} \mathrm{Y}_{0,08} \mathrm{O}_{3-\delta}, \quad \mathrm{BaZr}_{0,8} \mathrm{Y}_{0,2} \mathrm{O}_{3-\delta}$ e catodo cerâmico $\mathrm{La}_{0,6} \mathrm{Ca}_{0,4} \mathrm{Fe}_{0,8} \mathrm{Co}_{0,2} \mathrm{O}_{3-\delta}$ por mistura dos óxidos. Preparar $\mathrm{BaZr}_{0,85} \mathrm{Y}_{0,15} \mathrm{O}_{3-\delta}$ a partir de $\mathrm{BaO}$ e $\mathrm{ZrO}_{2}: 8 \mathrm{~mol}_{\%} \mathrm{Y}_{2} \mathrm{O}_{3}$.

- Preparar $\mathrm{BaCe}_{0,8} \mathrm{Gd}_{0,2} \mathrm{O}_{3-\delta}$ por mistura de óxidos.

- Caracterizar os eletrólitos sólidos condutores protônicos e o catodo.

- Montar células unitárias planares suportadas nos eletrólitos.

- Testar o potencial de circuito aberto e o potencial sob solicitação de carga de células unitárias planares usando como combustível $96 \% \mathrm{~N}_{2}-4 \% \mathrm{H}_{2}$ ou $\mathrm{CH}_{4}$.

- Caracterizar por meio de espectroscopia de impedância as células unitárias com eletrólito sólido de zirconato de bário. 


\section{Experimental}

\section{Preparação das amostras (eletrólito sólido)}

Foram preparados eletrólitos sólidos $\mathrm{BaZr}_{0,92} \mathrm{Y}_{0,08} \mathrm{O}_{3-\delta}, \mathrm{BaZr}_{0,8} \mathrm{Y}_{0,2} \mathrm{O}_{3-\delta}$ e $\mathrm{BaZr}_{0,85} \mathrm{Y}_{0,15} \mathrm{O}_{3-\delta}$ e cerato de bário $\quad \mathrm{BaCe}_{0,8} \mathrm{Gd}_{0,2} \mathrm{O}_{3-\delta}$.

Para a preparação do zirconato de bário dopados com ítria foram usados os seguintes materiais de partida: $\mathrm{BaO}, \mathrm{ZrO}_{2}$ e $\mathrm{Y}_{2} \mathrm{O}_{3}$ para as composições $\mathrm{BaZr}_{0,8} \mathrm{Y}_{0,2} \mathrm{O}_{3-\delta}$ e $\mathrm{BaZr}_{0,92} \mathrm{Y}_{0,08} \mathrm{O}_{3-\delta}$. $\mathrm{BaO}$ e zircônia estabilizada com ítria (pó comercial Tosoh, com 8 mol\% $\mathrm{Y}_{2} \mathrm{O}_{3}$ ) para a estequiometria $\mathrm{BaZr}_{0,85} \mathrm{Y}_{0,15} \mathrm{O}_{3-\delta}$. Foram calculadas as massas desses materiais, pesadas em balança analítica (Mettler H315), homogeneizadas em almofariz de ágata, calcinadas, conformadas em pastilhas, e sinterizadas. Foram também preparados pós cominuídos em moinho atritor. O processo será descrito a seguir.

Foi seguida uma rota alternativa com o pó de zirconato de bário com o objetivo de diminuir o tamanho médio de partícula e com isso aumentar a densidade do compacto sinterizado. Foram preparados $10 \mathrm{~g}$ do pó, colocados em um moinho atritor contendo $60 \mathrm{~mL}$ de esferas de zircônia-ítria tetragonal de diâmetro $2 \mathrm{~mm}$ e $30 \mathrm{~mL}$ de álcool etílico, agitados por $15 \mathrm{~min}$ a $500 \mathrm{rpm}$. Em seguida o álcool foi evaporado em estufa a $100^{\circ} \mathrm{C}$ e o pó cerâmico foi tratado a $1250{ }^{\circ} \mathrm{C} / 10 \mathrm{~h}$ com taxa de aquecimento e resfriamento de $10^{\circ} \mathrm{C} / \mathrm{min}$, e novamente preparado da mesma forma descrita anteriormente no moinho atritor, para então ser conformado e sinterizado a $1500{ }^{\circ} \mathrm{C} / 4 \mathrm{~h}$.

A Figura 8 mostra o esquema de um moinho atritor (recipiente e agitadores) contendo esferas de zircônia-ítria e o composto a ser atritado (pó e álcool etílico). 


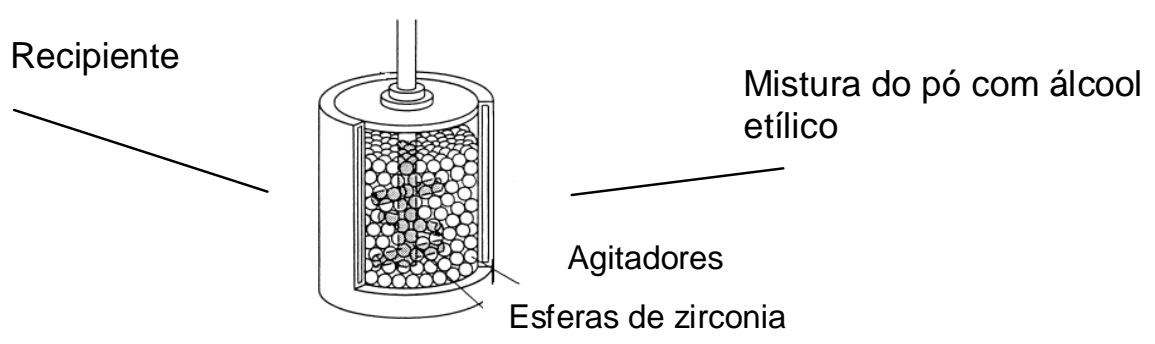

Figura 8: Esquema de um moinho atritor [75].

Para a preparação do cerato de bário foram calculadas as massas para a composição $\mathrm{BaCe}_{0,8} \mathrm{Gd}_{0,2} \mathrm{O}_{3-\delta}$, pesadas, misturadas e a mistura tratada termicamente a $1350{ }^{\circ} \mathrm{C} / 10 \mathrm{~h}$ com taxas de aquecimento e resfriamento de 10 $\stackrel{\circ}{\circ} / \mathrm{min}$.

\section{Preparação dos compactos cerâmicos}

Após a formação da fase, aferida por meio de análise de difração de raios $X$, os pós foram compactados em uma prensa hidráulica em matrizes metálicas de diâmetro $25 \mathrm{~mm}$, com uma carga de $\sim 2$ ton $\left(\sim 0,4\right.$ ton $\left./ \mathrm{cm}^{2}\right)$ e diâmetro de $12 \mathrm{~mm}$ com carga $\sim 0,6$ ton $\left(0,53 \mathrm{ton} / \mathrm{cm}^{2}\right)$ para pastilhas com espessura de $2 \mathrm{~mm}$.

As pastilhas de $\mathrm{BaCe}_{0,8} \mathrm{Gd}_{0,2} \mathrm{O}_{3-\delta}$, com e sem ligante orgânico, foram sinterizadas em um forno resistivo (Lindberg), com a seguinte programação: taxa de aquecimento e resfriamento $10 \stackrel{\circ}{\circ} /$ min e patamar $1500 \stackrel{\circ}{\circ} / 2 \mathrm{~h}$ para as pastilhas sem ligante orgânico (PVA, álcool polivinílico) e com taxa de aquecimento $5 \stackrel{\circ}{\circ} / \mathrm{min}$ até $500{ }^{\circ} \mathrm{C} / 10 \mathrm{~h}$, seguida de aquecimento a $10{ }^{\circ} \mathrm{C} / \mathrm{min}$ até $1500{ }^{\circ} \mathrm{C} / 2 \mathrm{~h}$ e resfriamento $10 \stackrel{\circ}{\circ} /$ min para as pastilhas com PVA, para a eliminação do material orgânico.

As pastilhas de $\mathrm{BaZr}_{0,92} \mathrm{Y}_{0,08} \mathrm{O}_{3-\delta}, \mathrm{BaZr}_{0,8} \mathrm{Y}_{0,2} \mathrm{O}_{3-\delta}$ e $\mathrm{BaZr}_{0,85} \mathrm{Y}_{0,15} \mathrm{O}_{3-\delta}$ foram sinterizadas a $1500{ }^{\circ} \mathrm{C} / 4 \mathrm{~h}$ com taxa de aquecimento e resfriamento $5^{\circ} \mathrm{C} / \mathrm{min}$.

\section{Anodo}

O anodo foi preparado por deposição de platina em meio orgânico diluído em clorofórmio, seguida de eliminação do material orgânico com tratamento 
térmico com taxa de aquecimento $5^{\circ} \mathrm{C} / \mathrm{min}$ até $300^{\circ} \mathrm{C} / 1 \mathrm{~h}$, novo aquecimento até $800^{\circ} \mathrm{C} / 10 \mathrm{~min}$ com taxas de aquecimento e resfriamento $5^{\circ} \mathrm{C} / \mathrm{min}$.

\section{$\underline{\text { Catodo }}$}

Foram usados dois tipos de catodo: Platina e $\mathrm{La}_{0,6} \mathrm{Ca}_{0,4} \mathrm{Fe}_{0,8} \mathrm{Co}_{0,2} \mathrm{O}_{3-\delta}$. A Tabela 2 mostra os materiais de partida para a preparação do catodo.

Tabela 2: Substâncias usadas para obtenção do catodo $\mathrm{La}_{0,6} \mathrm{Ca}_{0,4} \mathrm{Fe}_{0,8} \mathrm{Co}_{0,2} \mathrm{O}_{3-\delta}$ : massa, grau de pureza e origem ou marca do produto.

\begin{tabular}{lccc}
\hline \multicolumn{1}{c}{ Material de partida } & Massa para $10 \mathrm{~g}$ & $\begin{array}{c}\text { Pureza } \\
(\%)\end{array}$ & Origem \\
\hline óxido de lantânio $\left(\mathrm{La}_{2} \mathrm{O}_{3}\right)$ & 4,597 & 99,99 & - \\
carbonato de cálcio $\left(\mathrm{CaCO}_{3}\right)$ & 1,883 & 99,5 & Alfa Aesar \\
óxido de ferro $\left(\mathrm{Fe}_{2} \mathrm{O}_{3}\right)$ & 3,005 & - & - \\
trióxido de cobalto $\left(\mathrm{Co}_{3} \mathrm{O}_{4}\right)$ & 0,515 & 95 & ACS \\
\hline
\end{tabular}

Foram calculadas as massas dos óxidos de lantânio, de ferro e de cobalto juntamente com carbonato de cálcio para preparar um total de $10 \mathrm{~g}$ de $\mathrm{La}_{0,6} \mathrm{Ca}_{0,4} \mathrm{Fe}_{0,8} \mathrm{Co}_{0,2} \mathrm{O}_{3-\delta}$. A mistura dos pós foi homogeneizada em almofariz de ágata, seguida de homogeneização em agitador mecânico por $1 \mathrm{~h}$ em meio álcool isopropílico e evaporação a $50 \stackrel{\circ}{C}$.

A equação 10 mostra a reação dos óxidos para a formação do catodo.

$$
0,3 \mathrm{La}_{2} \mathrm{O}_{3}+0,4 \mathrm{CaCO}_{3}+0,4 \mathrm{Fe}_{2} \mathrm{O}_{3}+0,2 / 3 \mathrm{Co}_{3} \mathrm{O}_{4} \rightarrow \mathrm{La}_{0,6} \mathrm{Ca}_{0,4} \mathrm{Fe}_{0,8} \mathrm{Co}_{0,2} \mathrm{O}_{2,74}+0,4 \mathrm{CO}_{2}
$$

Para a deposição, foi feita uma solução com 0,25 $g$ de $\mathrm{La}_{0,6} \mathrm{Ca}_{0,4} \mathrm{Fe}_{0,8} \mathrm{Co}_{0,2} \mathrm{O}_{3-\delta}+0,25 \mathrm{~g}$ de $\mathrm{BaCe}_{0,8} \mathrm{Gd}_{0,2} \mathrm{O}_{3-\delta}$ e/ou $\mathrm{BaZr}_{0,92} \mathrm{Y}_{0,08} \mathrm{O}_{3-\delta}$, $\mathrm{BaZr}_{0,8} \mathrm{Y}_{0,2} \mathrm{O}_{3-\delta}$ e $\mathrm{BaZr}_{0,85} \mathrm{Y}_{0,15} \mathrm{O}_{3-\delta}+3$ gotas de PVB e $2 \mathrm{~mL}$ de álcool etílico.

As pastilhas sinterizadas de $\mathrm{BaCe}_{0,8} \mathrm{Gd}_{0,2} \mathrm{O}_{3-\delta}, \quad \mathrm{BaZr}_{0,92} \mathrm{Y}_{0,08} \mathrm{O}_{3-\delta}$, $\mathrm{BaZr}_{0,8} \mathrm{Y}_{0,2} \mathrm{O}_{3-\delta}$ e $\mathrm{BaZr}_{0,85} \mathrm{Y}_{0,15} \mathrm{O}_{3-\delta}$, com o catodo depositado, foram tratadas termicamente para fixação do catodo a $1150 \stackrel{\circ}{\mathrm{C}}$ por $0,5 \mathrm{~h}$ com taxa de aquecimento e resfriamento $3^{\circ} \mathrm{C} / \mathrm{min}$. 


\section{Caracterização dos pós cerâmicos}

\section{Difracão de raios $X$}

As amostras de cerato de bário e zirconato de bário foram analisadas por difração de raios $X$ em um difratômetro Bruker-AXS D8 Advance, com radiação Cuk $_{\alpha}$ na faixa angular de $20^{\circ}$ a $80^{\circ}(2 \theta)$, com passo de $0,05^{\circ}$ e tempo por passo $3 \mathrm{~s}$.

\section{Distribuição do tamanho de partícula}

A análise de distribuição de partículas, por espalhamento laser, dos pós cerâmicos de $\mathrm{BaZr}_{0,92} \mathrm{Y}_{0,08} \mathrm{O}_{3-\delta}$ e $\mathrm{BaZr}_{0,85} \mathrm{Y}_{0,15} \mathrm{O}_{3-\delta}$ preparados por mistura de óxidos e após moagem em moinho atritor foi feita com uma amostragem de aproximadamente $1 \mathrm{~g}$ à temperatura ambiente, sendo dispersa em água com pirofosfato de sódio e a dispersão feita em ultra-som (Vibracell Sonics \& Materials) durante 5 min. O equipamento utilizado foi o Granulômetro Cilas 1064.

\section{Análise térmica}

Análise termogravimétrica e análise térmica diferencial do composto cerâmico $\mathrm{BaZr}_{0,85} \mathrm{Y}_{0,15} \mathrm{O}_{3-\delta}$ foram feitas com taxa de aquecimento $10{ }^{\circ} \mathrm{C} / \mathrm{min}$ até $1500{ }^{\circ} \mathrm{C}$ sob atmosfera de ar sintético, com material de referência alumina alfa e amostragem de 50 mg. O equipamento usado foi Netzsch modelo STA 409.

\section{Caracterização dos compactos sinterizados}

\section{Densidade aparente}

As medidas de densidade foram de dois tipos: densidade geométrica com um micrômetro TESA e avaliação da massa por pesagem em balança analítica, e pela técnica de Arquimedes em meio líquido (querosene) [76].

\section{Difração de raios X}

Os compactos foram analisados por difração de raios $X$ com o mesmo equipamento usado para pós, descrito anteriormente. 


\section{Microscopia eletrônica de varredura}

Os compactos cerâmicos sinterizados foram fraturados e fixados sobre porta-amostra com auxílio de uma pasta fixadora de carbono, pintados com prata e em seguida recobertos com ouro por sputtering. As superfícies de fratura foram observadas em microscópio eletrônico de varredura modelo LEO 440I Oxford.

\section{Montagem das células}

A Tabela 3 mostra as configurações estudadas de células a combustível.

Tabela 3: Tipos de células montadas para teste.

\begin{tabular}{|c|c|}
\hline Número da célula & Configuração \\
\hline 1 & $\mathrm{LCFC} / \mathrm{BaCe}_{0,8} \mathrm{Gd}_{0,2} \mathrm{O}_{3-\delta} / \mathrm{Pt}$ \\
\hline 2 & $\mathrm{Pt} / \mathrm{BaCe}_{0,8} \mathrm{Gd}_{0,2} \mathrm{O}_{3-\delta} / \mathrm{Pt}^{*}$ \\
\hline 3 & $\mathrm{LCFC} \mathrm{BaZr}_{0,92} \mathrm{Y}_{0,08} \mathrm{O}_{3-\delta} / \mathrm{Pt}$ \\
\hline 4 & $\mathrm{LCFC} / \mathrm{BaZr}_{0,92} \mathrm{Y}_{0,08} \mathrm{O}_{3-\delta} / \mathrm{Pt}^{*}$ \\
\hline 5 & $\mathrm{LCFC} / \mathrm{BaZr}_{0,8} \mathrm{Y}_{0,2} \mathrm{O}_{3-\delta} / \mathrm{Pt}^{*}$ \\
\hline 6 & LCFC/BaZr ${ }_{0,85} \mathrm{Y}_{0,15} \mathrm{O}_{3-\delta} / \mathrm{Pt}$ \\
\hline 7 & $\mathrm{LCFC} / \mathrm{BaZr}_{0,85} \mathrm{Y}_{0,15} \mathrm{O}_{3-\delta} / \mathrm{Pt}^{*}$ \\
\hline
\end{tabular}

*Pós preparados com moinho atritor.

As células 1 e 7 foram montadas em porta-amostra, construído para evitar vazamentos, e seladas a um tubo de alumina; as células 2, 3, 4, 5 e 6 foram seladas diretamente no tubo de alumina usando como selante um vidro desenvolvido no laboratório [77], e inseridas em forno bi-partido vertical.

As células foram montadas para medidas de potencial de circuito aberto, potencial sob carga e espectroscopia de impedância usando uma interface eletroquímica composta por analisador de impedância Solartron 1260 e interface Solartron 1287, operando com gás metano ou hidrogênio na região do anodo e ar ambiente na região do catodo, na faixa de temperatura $300-600 \stackrel{\circ}{C}$. 
A Figura 9 mostra o sistema de medidas de potencial de circuito aberto e curva corrente-tensão: interface eletroquímica Solartron SI 1287 e analisador de impedância Solartron SI 1260 (esquerda), e forno resistivo vertical (direita).

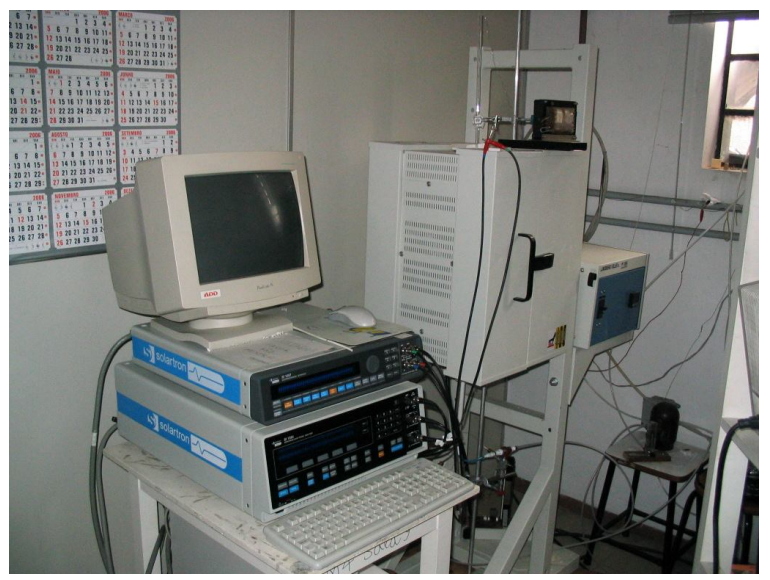

Figura 9: Sistema de medidas de potencial de circuito aberto e curva tensãocorrente (esquerda) e forno resistivo vertical (direita).

A Figura 10 mostra como foram feitas as montagens para teste das células, de dois tipos: (a) em uma câmara de material refratário com o selante fixado por cima da célula e (b) diretamente no tubo de alumina com o selante colocado por baixo da amostra; ambas montagens forneceram bons resultados, isto é, permitiram a operação da célula na faixa de temperatura 300-600 ${ }^{\circ} \mathrm{C}$ sem perceptível vazamento de combustível.

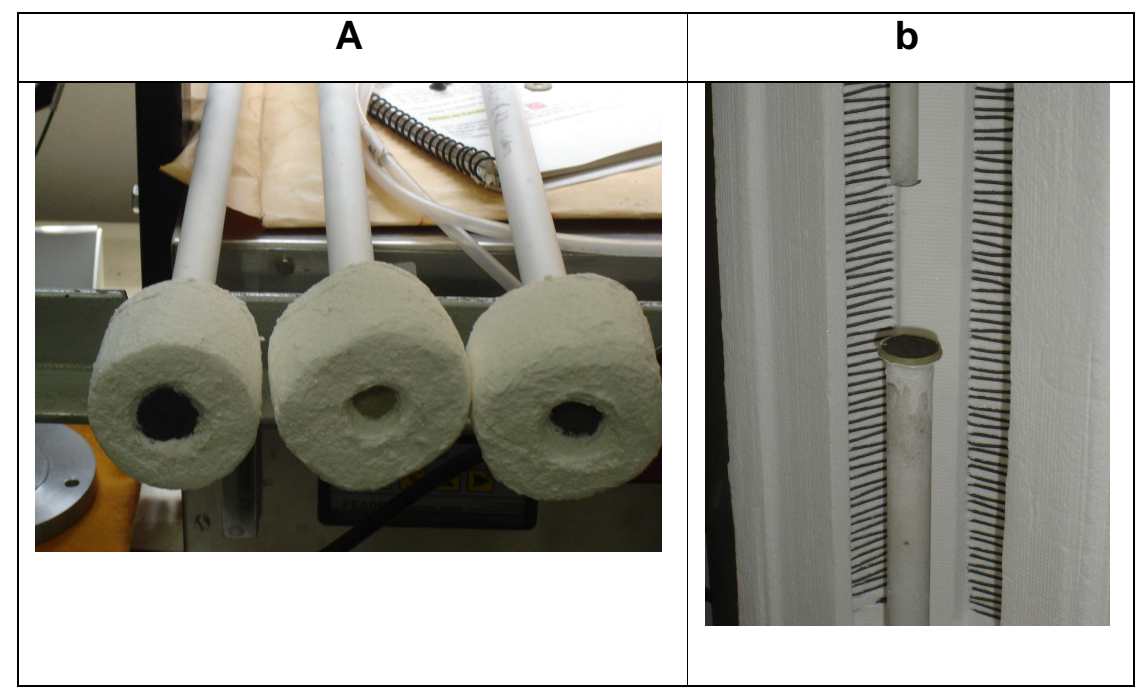


Figura 10: Montagem da SOFC em tubo de alumina com porta-amostra de tijolo refratário (a) e diretamente no tubo de alumina (b).

A Figura 11 mostra o perfil de temperatura e tempo adotado para as medidas de OCV e potencial sob solicitação de carga (IV).

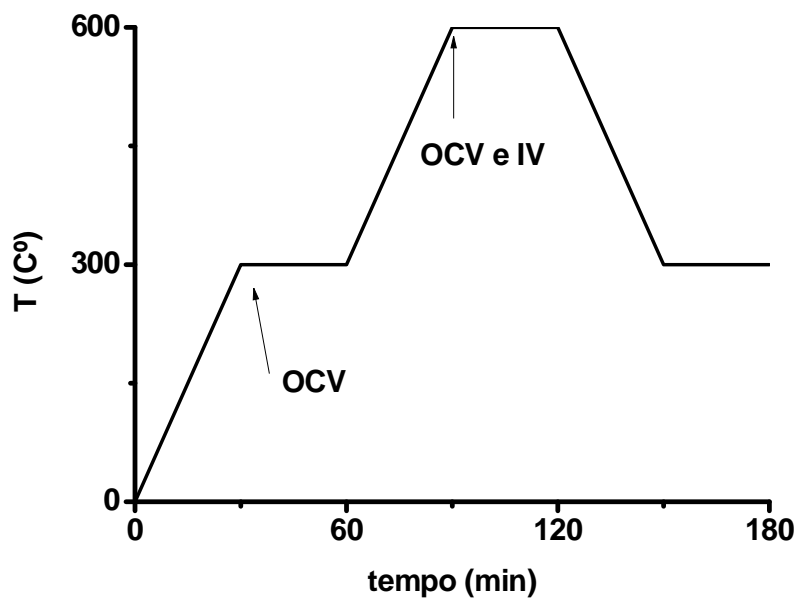

Figura 11: Perfil de aquecimento e resfriamento, tempo e temperatura de patamar na operação das células. OCV: de potencial de circuito aberto; IV: de correntetensão.

A Figura 12 mostra o esquema simplificado dos dois tipos de montagem das células a combustível. 


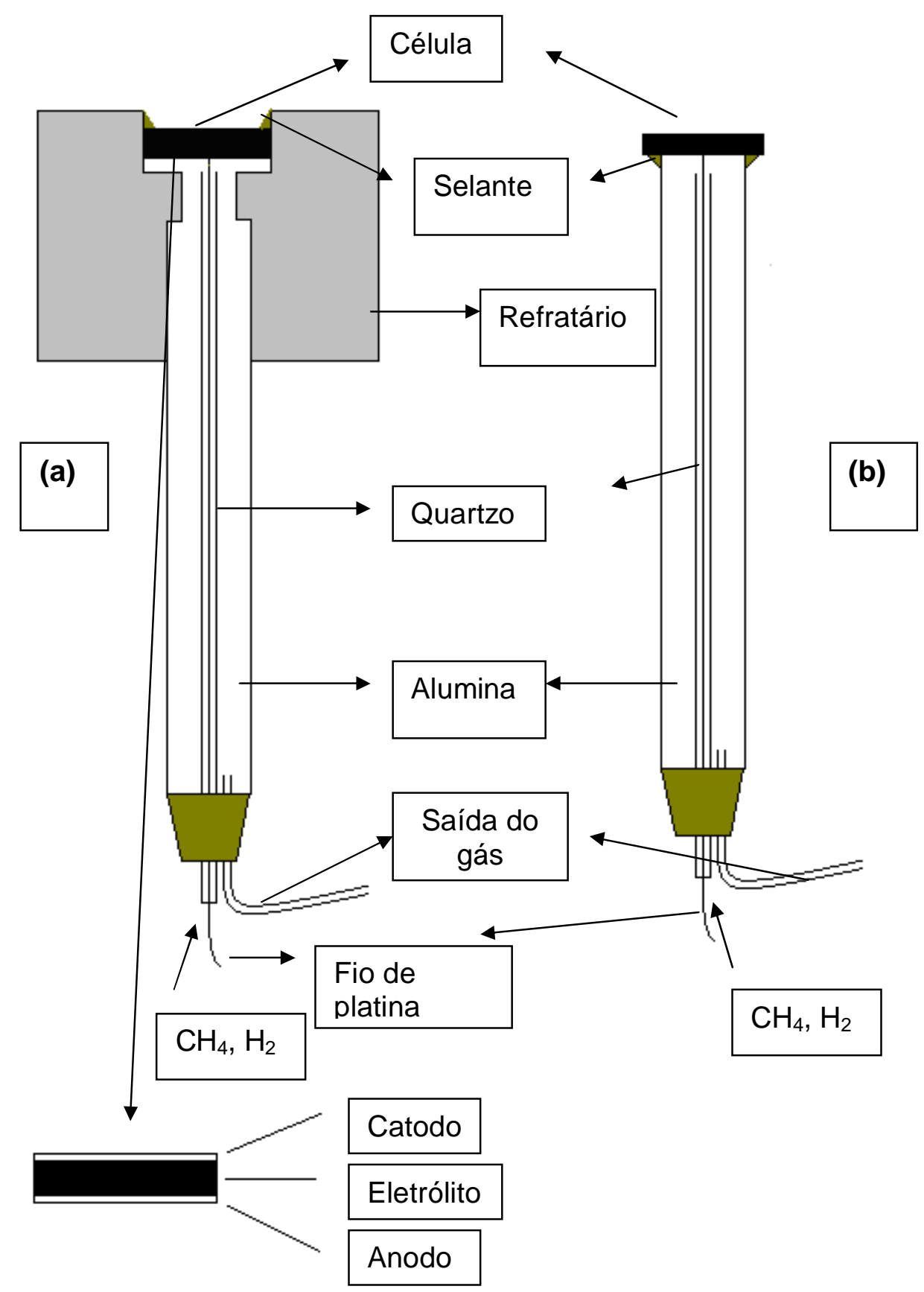

Figura 12: Esquema de dois tipos de montagem da célula a combustível unitária, com porta-amostra de tijolo refratário (a) e selado diretamente no tubo de alumina (b). 


\section{Resultados}

\section{A. Materiais de partida}

A Figura 13 mostra os resultados das análises termogravimétrica e térmica diferencial dos materiais usados para preparar o composto $\mathrm{BaZr}_{0,85} \mathrm{Y}_{0,15} \mathrm{O}_{3-\delta}$ por mistura de zircônia estabilizada com ítria e óxido de bário.

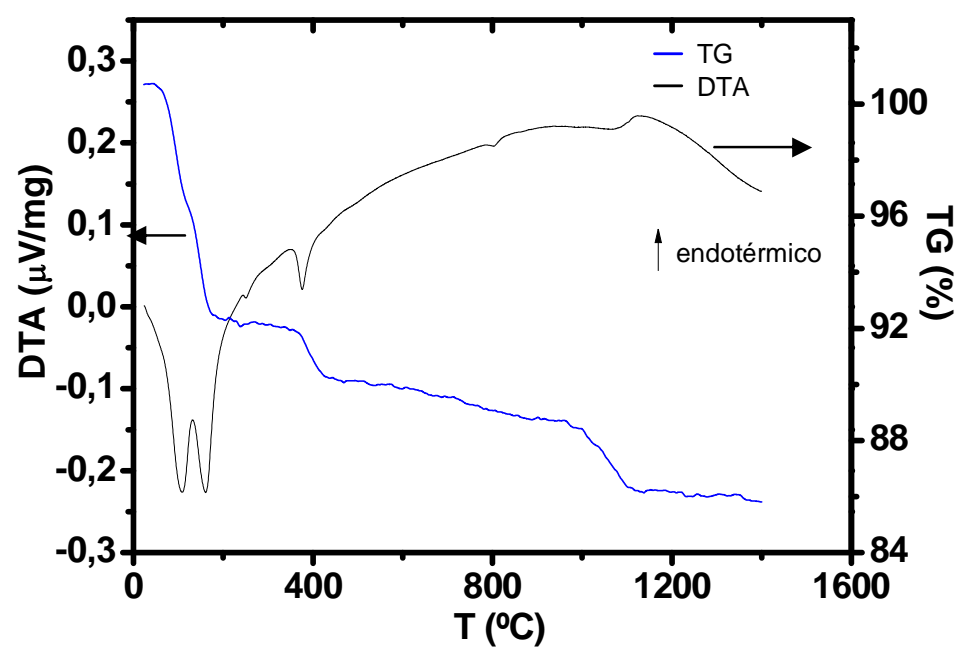

Figura 13: Curvas termogravimétrica (TG) e térmica diferencial (ATD) da mistura de pós para formação do composto $\mathrm{BaZr}_{0,85} \mathrm{Y}_{0,15} \mathrm{O}_{3-\delta}$.

Há uma perda de $\sim 14 \%$ da massa total dividida em três faixas de temperatura. A primeira, da temperatura ambiente até $\sim 200^{\circ} \mathrm{C}$ atribuída à perda de água adsorvida e à decomposição do hidróxido de bário proveniente da adsorção de água no óxido de bário. O pico endotérmico em aproximadamente $130{ }^{\circ} \mathrm{C}$ é devido à decomposição do hidróxido de bário por causa da reação que ocorre na temperatura ambiente com umidade. O pico exotérmico em $\sim 378{ }^{\circ} \mathrm{C}$ é provavelmente resultado da reação do hidróxido de bário anidro com oxigênio formando peróxido de bário. Em $\sim 800{ }^{\circ} \mathrm{C}$ há um pico exotérmico atribuído à decomposição do carbonato de bário. O outro pico a $\sim 1080{ }^{\circ} \mathrm{C}$ é devido a transformação de fase do material onde também houve perda de massa por causa da evaporação do óxido de bário. Estes resultados mostram que a reação para a formação do composto $\mathrm{BaZr}_{0,85} \mathrm{Y}_{0,15} \mathrm{O}_{3-\delta}$ se completa na faixa entre a temperatura ambiente e $\sim 1200^{\circ} \mathrm{C}$. 


\section{Difracão de raios $\mathrm{X}$}

A Figura 14 mostra o difratograma de raios $\mathrm{X}$ de $\mathrm{BaZr}_{0,92} \mathrm{Y}_{0,08} \mathrm{O}_{3-\delta}$ na forma de pó calcinado a $1250{ }^{\circ} \mathrm{C}$ durante $10 \mathrm{~h}$ com taxas de aquecimento e resfriamento $10^{\circ} \mathrm{C} / \mathrm{min}(\mathrm{a})$, e após moagem em moinho atritor (b).
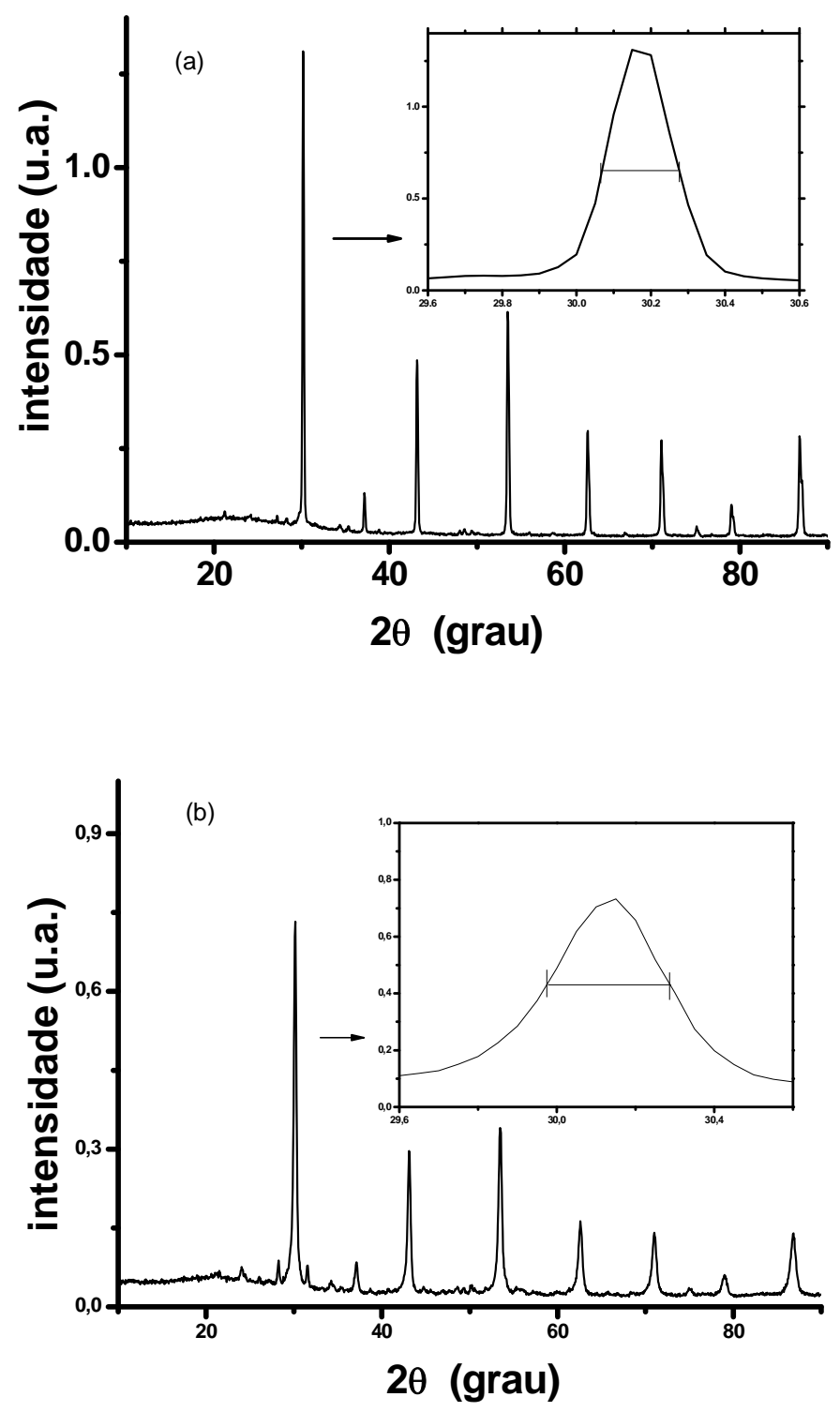

Figura 14: Difratogramas de raios $\mathrm{X}$ do pó calcinado de $\mathrm{BaZr_{0,92 }} \mathrm{Y}_{0,08} \mathrm{O}_{3-\delta}$ preparado por mistura de óxidos (a) e submetido a moagem em moinho atritor (b). 
Os difratogramas mostram a formação da fase cúbica característica do composto $\mathrm{BaZr}_{0,92} \mathrm{Y}_{0,08} \mathrm{O}_{3-\delta .}$. As diferenças entre as larguras a meia altura dos picos do difratograma do pó preparado por mistura de óxidos e do pó submetido à moagem, mostram a variação no tamanho médio de cristalito. $O$ tamanho de cristalito foi calculado segundo a equação (10), sendo que $\beta$ foi determinado com base na convolução de uma distribuição Cauchy e uma Gaussiana [78].

$$
L=0,9 \lambda /(\beta \cos \theta)
$$

Para o difratograma da Figura 14a foi calculado o tamanho de cristalito de $\sim 2880 \AA ̊$ e para o da Figura 14b $\sim 445 \AA$.

\section{Distribuicão de tamanho de partículas}

As Figuras 15 e 16 mostram a distribuição de tamanho de partículas do composto $\mathrm{BaZr}_{0,92} \mathrm{Y}_{0,08} \mathrm{O}_{3-\delta}$ preparado pela técnica de mistura de óxidos e após moagem em moinho atritor, respectivamente.

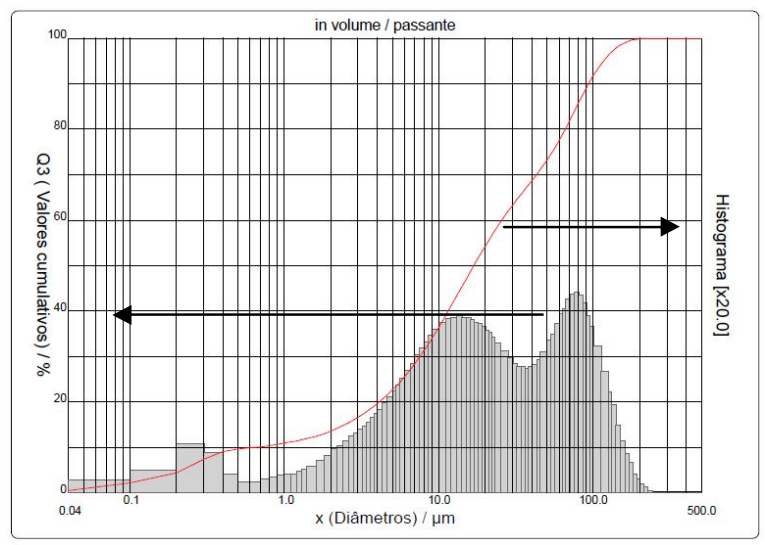

Figura 15: Distribuição de tamanho de partícula do $\mathrm{BaZr}_{0,92} \mathrm{Y}_{0,08} \mathrm{O}_{3-\delta}$ preparado pela técnica de mistura de óxidos.

A distribuição é bimodal centralizada em 10,5 $\mu \mathrm{m}$ e $80 \mu \mathrm{m}$ e o diâmetro médio (maior parte das partículas) é $34 \mu \mathrm{m}$.

O tamanho médio de partículas é um parâmetro importante para o processamento de materiais cerâmicos quando se utiliza como técnica de 
preparação a mistura de pós, especialmente no caso de eletrólitos sólidos que necessitam uma alta densificação.

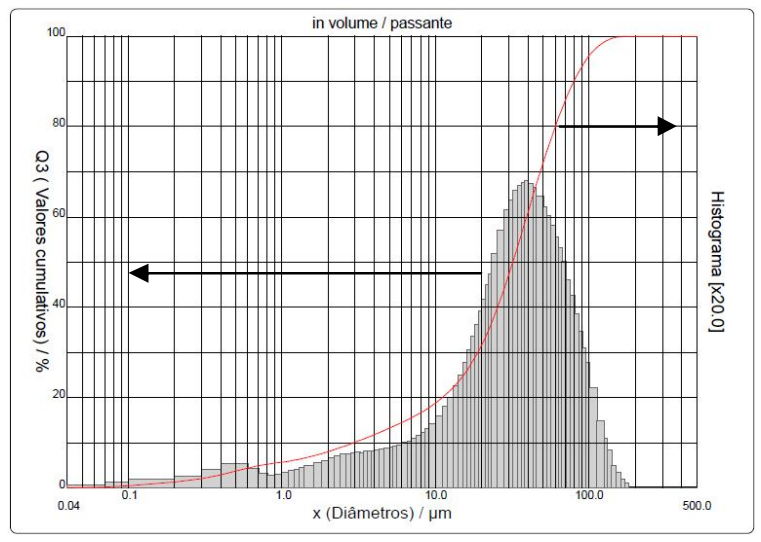

Figura 16: Distribuição do tamanho de partículas do $\mathrm{BaZr}_{0,92} \mathrm{Y}_{0,08} \mathrm{O}_{3-\delta}$ preparado por mistura de óxidos e submetido a moagem em moinho atritor.

A Figura 16 mostra uma distribuição bimodal e o diâmetro médio aferido é $37,6 \mu \mathrm{m}$, maior do que do pó preparado sem moagem.

Os pós finos tendem a se aglomerar provavelmente por meio do calor recebido pelo atrito entre os meios de moagem.

As Figuras 17 e 18 mostram a distribuição de tamanho de partículas do composto $\mathrm{BaZr}_{0,85} \mathrm{Y}_{0,15} \mathrm{O}_{3-\delta}$ preparado por técnica de mistura de óxidos partindo de $\mathrm{BaO}$ e $\mathrm{ZrO}_{2}: 8 \%$ mol de $\mathrm{Y}_{2} \mathrm{O}_{3}$, e após moagem em moinho atritor, respectivamente.

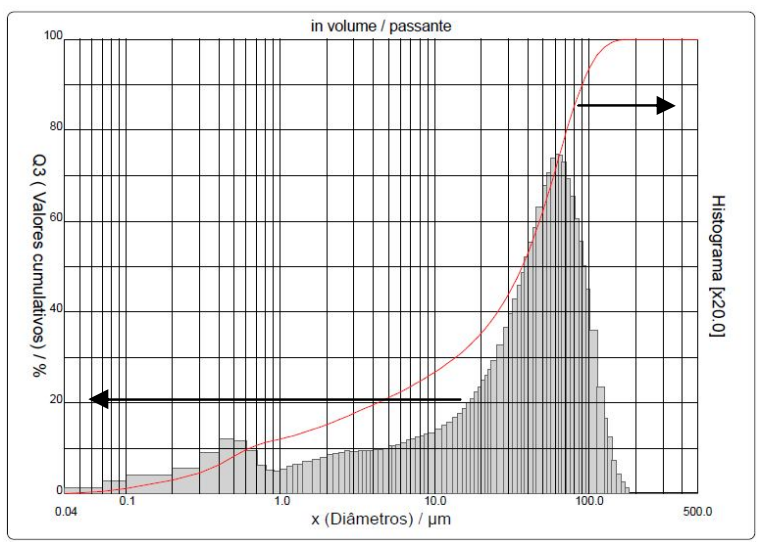

Figura 17: Distribuição do tamanho de partículas de $\mathrm{BaZr}_{0,85} \mathrm{Y}_{0,15} \mathrm{O}_{3-\delta}$ preparado por mistura de $\mathrm{BaO}$ com $\mathrm{ZrO}_{2}: 8 \mathrm{~mol}_{\%} \mathrm{Y}_{2} \mathrm{O}_{3}$. 


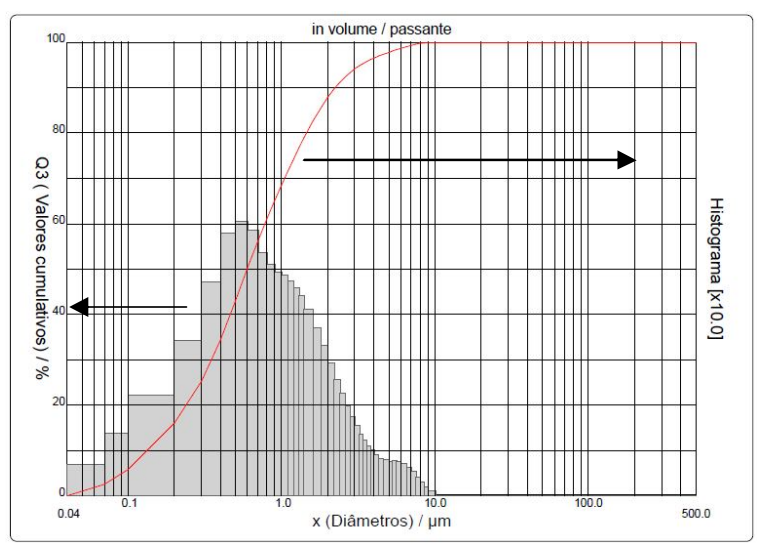

Figura 18: Distribuição do tamanho de partículas de $\mathrm{BaZr}_{0,85} \mathrm{Y}_{0,15} \mathrm{O}_{3-\delta}$ preparado por mistura de $\mathrm{BaO}$ com $\mathrm{ZrO}_{2}: 8 \mathrm{~mol}_{\%} \mathrm{Y}_{2} \mathrm{O}_{3}$ e submetidos a moagem em moinho atritor.

A Figura 17 apresenta uma distribuição bimodal e o diâmetro médio aferido é $\sim 1 \mu \mathrm{m}$.

A Figura 18 apresenta uma distribuição bimodal e o diâmetro médio aferido é $\sim 1 \mu \mathrm{m}$, menor do que do pó preparado sem moagem.

O pó submetido à moagem apresentou um tamanho de partícula muito inferior aos apresentados até agora, demonstrando que a moagem foi eficiente para este pó. 


\section{A.1 Eletrólitos sólidos}

\section{Densidade}

Foram preparadas composições de $\mathrm{BaZr}_{0,92} \mathrm{Y}_{0,08} \mathrm{O}_{3-\delta}(1)$ e $\mathrm{BaZr}_{0,85} \mathrm{Y}_{0,15} \mathrm{O}_{3-\delta}$ (2) por dois métodos.

1- Mistura de $\mathrm{BaO}, \mathrm{ZrO}_{2}$ e $\mathrm{Y}_{2} \mathrm{O}_{3}\left(\mathrm{O}_{53}\right)$ e por moagem em moinho atritor (composição $\mathrm{O}_{54}$ );

2- Mistura de óxidos de $\mathrm{BaO}$ e $\mathrm{ZrO}_{2}: 8 \%$ mol de $\mathrm{Y}_{2} \mathrm{O}_{3}\left(\mathrm{O}_{20}\right)$ e por moagem (composição $\mathrm{O}_{52}$ ). Em seguida foi feita a compactação e os corpos compactados submetidos a tratamento térmico de $1500{ }^{\circ} \mathrm{C} / 4 \mathrm{~h}$ com taxas de aquecimento e resfriamento $5^{\circ} \mathrm{C} / \mathrm{min}$. A Tabela 4 mostra os valores de densidade geométrica e a determinada pelo método de Arquimedes.

Tabela 4 - Densidades de compactos cerâmicos de $\mathrm{BaZr}_{0,92} \mathrm{Y}_{0,08} \mathrm{O}_{3-\delta}$ e $\mathrm{BaZr}_{0,85} \mathrm{Y}_{0,15} \mathrm{O}_{3-\delta}$ sinterizados a $1500{ }^{\circ} \mathrm{C} / 4 \mathrm{~h}$.

\begin{tabular}{ccccc}
\hline $\begin{array}{c}\text { Amostras } \\
\mathrm{BaZr}_{0,92} \mathrm{Y}_{0,08} \mathrm{O}_{3-\delta} \\
\mathrm{e}\end{array}$ & $\begin{array}{c}\text { Densidade } \\
\text { geométrica } \\
\left(\mathrm{g} / \mathrm{cm}^{3}\right)\end{array}$ & $\begin{array}{c}\text { Densidade } \\
\text { densidade } \\
\text { teórica* }\end{array}$ & $\begin{array}{c}\text { \% densidade } \\
\text { pelo método } \\
\text { de } \\
\text { teórica* }\end{array}$ & $\begin{array}{c}\text { Arquimedes } \\
\left(\mathrm{g} / \mathrm{cm}^{3}\right)\end{array}$ \\
\hline $\mathrm{O}_{53}$ & 4,06 & 65,6 & 6,00 & 96,9 \\
$\mathrm{O}_{54}$ & 3,56 & 57,5 & 5,84 & 94,3 \\
$\mathrm{O}_{20}$ & 4,01 & 63,9 & 5,62 & 90,7 \\
$\mathrm{O}_{52}$ & 2,82 & 45,6 & 5,65 & 91,2 \\
\hline
\end{tabular}

${ }^{*}$ densidade teórica $6,19 \mathrm{~g} / \mathrm{cm}^{3}$.

\section{Cálculo da densidade}

A densidade foi calculada por meio da determinação dos parâmetros de rede da célula unitária pela técnica de difração de raios $X$ (para avaliação do 
volume da célula unitária pelo parâmetro de rede calculado [79]) e pelas massas dos átomos que compõem a célula unitária. O valor determinado foi $6,19 \mathrm{~g} / \mathrm{cm}^{3}$.

\section{Difracão de raios $\mathrm{X}$}

A Figura 19 mostra difratogramas de raios $X$ da composição $\mathrm{BaZr}_{0,92} \mathrm{Y}_{0,08} \mathrm{O}_{3-\delta}$ após sinterização a $1500{ }^{\circ} \mathrm{C} / 4 \mathrm{~h}$, juntamente com as principais raias do composto $\mathrm{BaZr}_{0,92} \mathrm{Y}_{0,08} \mathrm{O}_{3-\delta}$ (arquivo JCPDS 6-399).

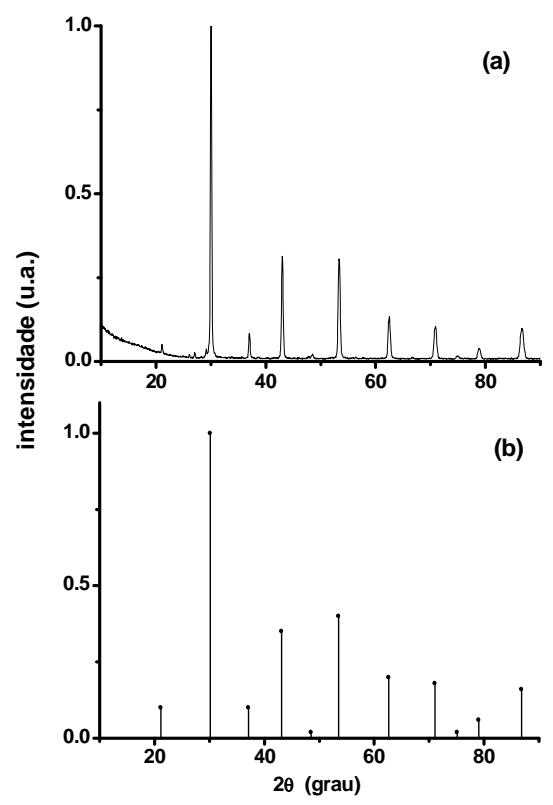

Figura 19: Difratograma de raios $X$ da superfície da pastilha sinterizada de $\mathrm{BaZr}_{0,92} \mathrm{Y}_{0,08} \mathrm{O}_{3-\delta}$ preparada por mistura de óxidos (a); raias de difração de $\mathrm{BaZr}_{0,92} \mathrm{Y}_{0,08} \mathrm{O}_{3-\delta}$ (JCPDS 6-399) (b).

Os difratogramas de raios $\mathrm{X}$ foram analisados por comparação com o arquivo JCPDS 6-399 do composto $\mathrm{BaZr}_{0,92} \mathrm{Y}_{0,08} \mathrm{O}_{3-\delta}$. As pastilhas sinterizadas tem estrutura cristalina cúbica, característica do composto $\mathrm{BaZr}_{0,92} \mathrm{Y}_{0,08} \mathrm{O}_{3-\delta}$. A diferença entre o difratograma da pastilha para o do pó está na largura da meia altura das raias de difração, que mostram crescimento de cristalito durante a sinterização. 


\section{Microscopia eletrônica de varredura}

Na Figura 20 são apresentadas as micrografias de superfícies de fratura dos compactos de $\mathrm{BaZr}_{0,92} \mathrm{Y}_{0,08} \mathrm{O}_{3-\delta}$ sinterizados a $1500{ }^{\circ} \mathrm{C} / 4 \mathrm{~h}$, por mistura em almofariz de ágata (a),(b) e (c); e submetidos ao moinho atritor (d), (e) e (f).

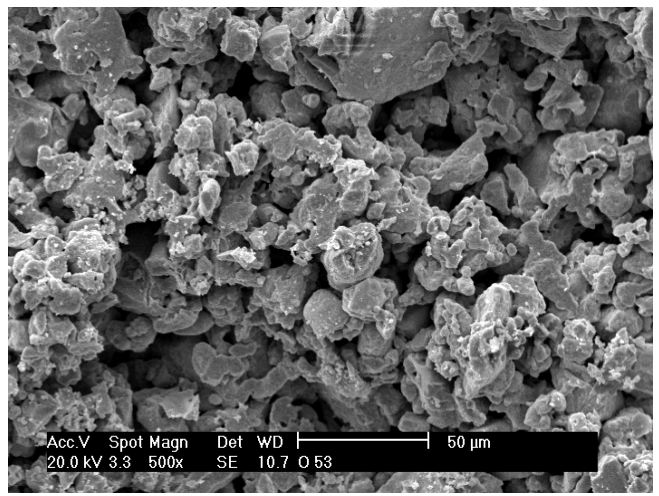

(a)

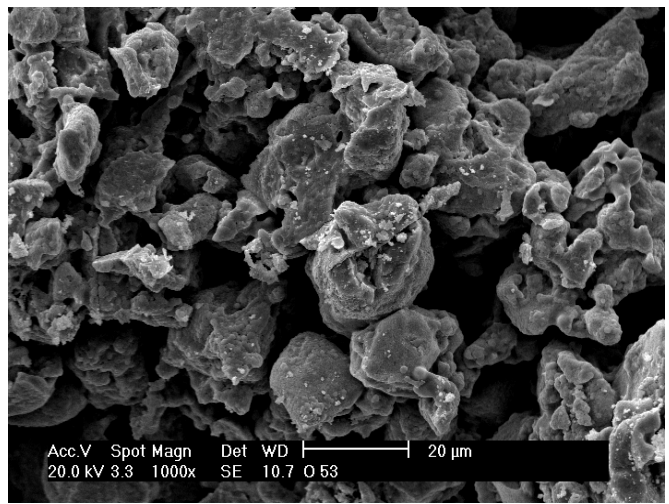

(b)

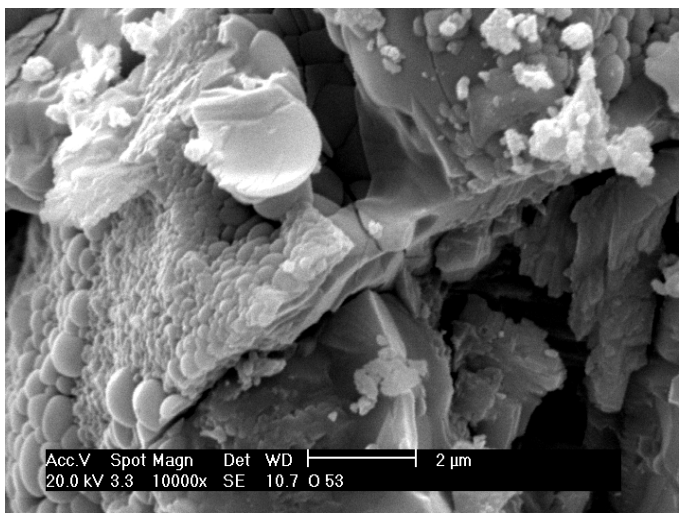

(c)

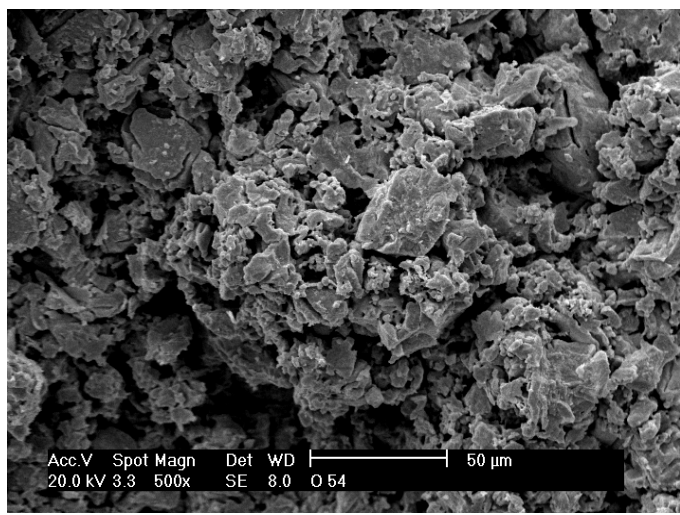

(d)

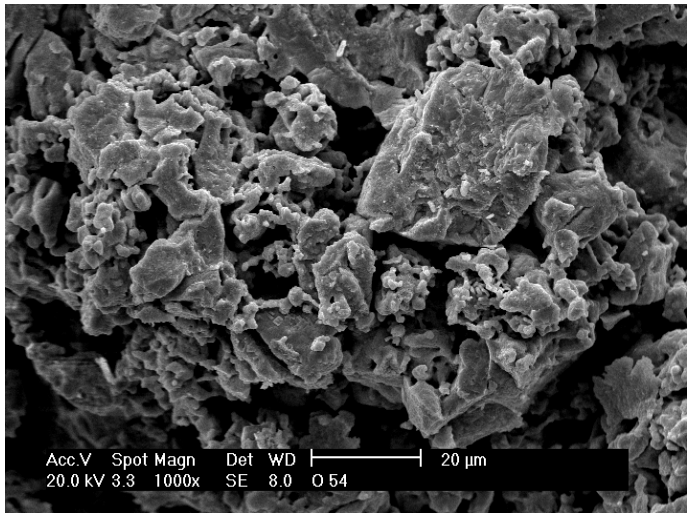

(e)

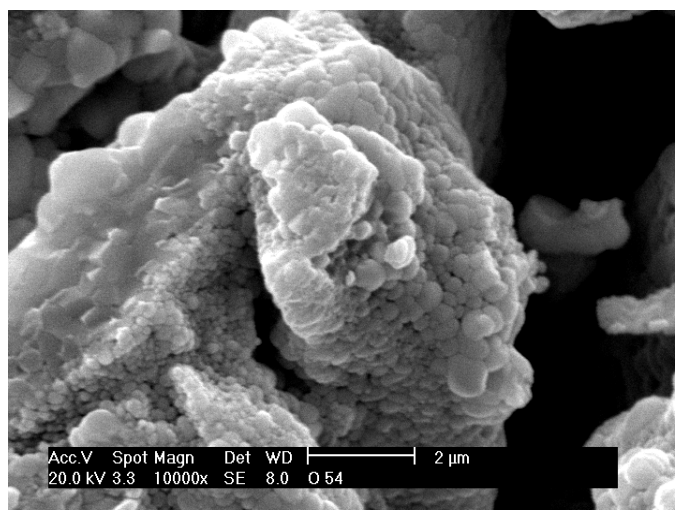

(f)

Figura 20: Micrografias obtidas por microscopia eletrônica de varredura das superfícies de fratura do composto $\mathrm{BaZr}_{0,92} \mathrm{Y}_{0,08} \mathrm{O}_{3-\delta}$. 
Em todas as micrografias é possível notar a alta porosidade característica desse material. Há diferenças na forma e no tamanho dos grãos entre os dois tipos de compactos cerâmicos preparados. O material preparado por mistura manual em almofariz de ágata apresenta uma forma mais arredondada enquanto o material submetido ao moinho de alta energia tem uma forma menos arredondada e uma pequena redução da porosidade aberta, porém com aglomerados maiores.

Na Figura 21 são apresentadas as micrografias de superfícies de fratura dos compactos de $\mathrm{BaZr}_{0,85} \mathrm{Y}_{0,15} \mathrm{O}_{3-8}$ preparados com $\mathrm{ZrO}_{2}: 8 \%$ mol de $\mathrm{Y}_{2} \mathrm{O}_{3} \mathrm{e}$ sinterizados a $1500{ }^{\circ} \mathrm{C} / 4 \mathrm{~h}$, por mistura em almofariz de ágata (a),(b) e (c); e submetidos a moagem em moinho atritor (d), (e) e (f).

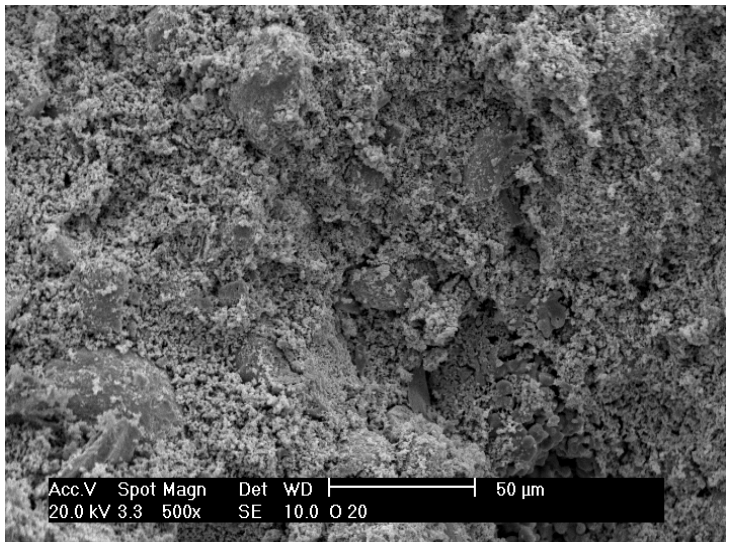

(a)

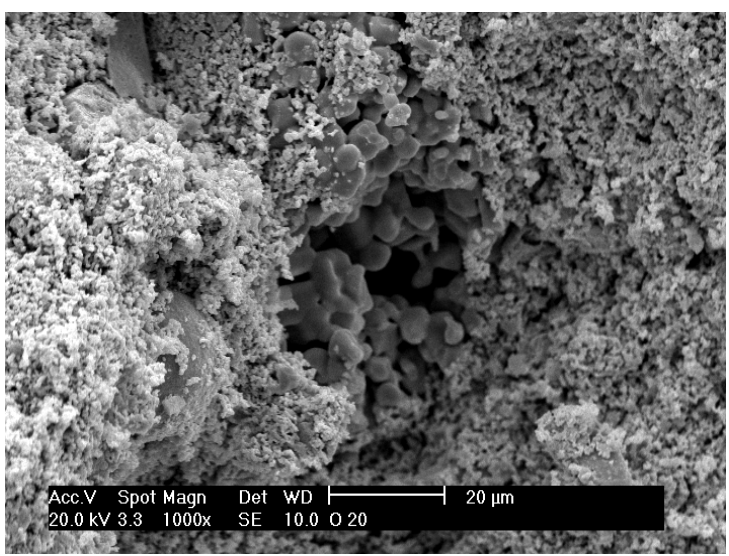

(b)

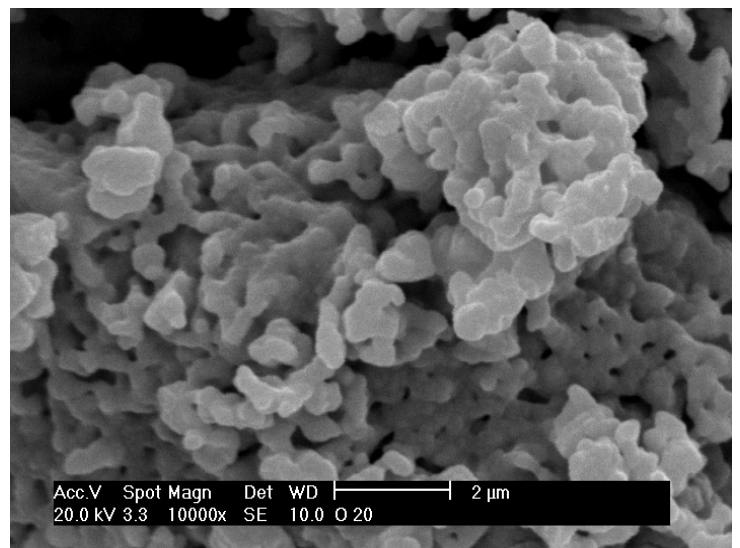

(c)

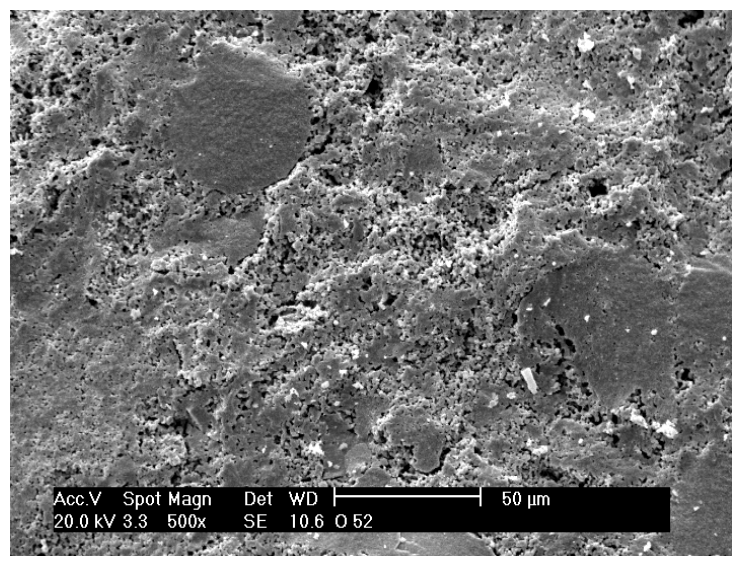

(d) 


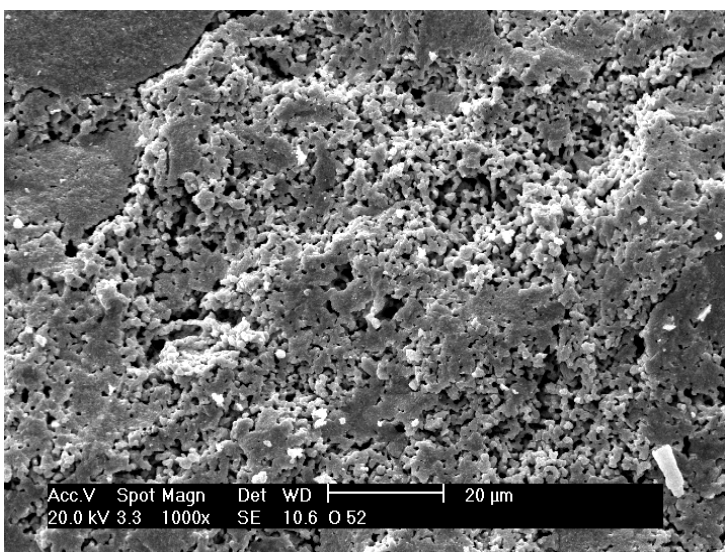

(e)

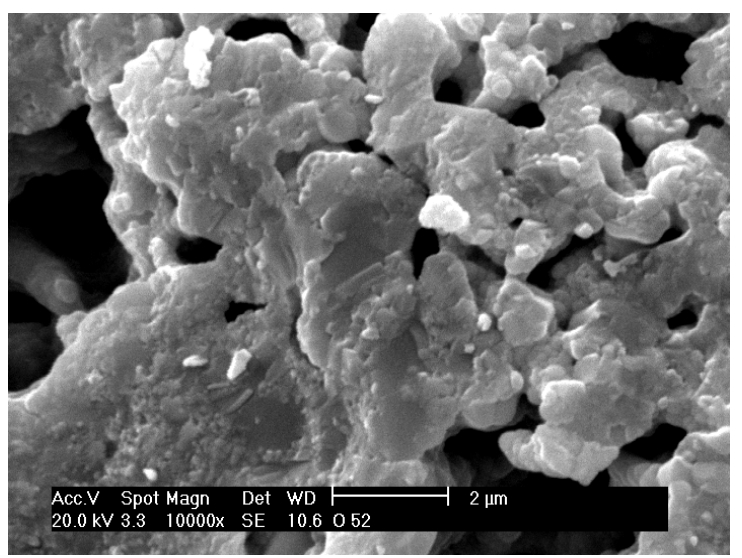

(f)

Figura 21: Micrografias obtidas por microscopia eletrônica de varredura das superfícies de fratura do composto $\mathrm{BaZr}_{0,85} \mathrm{Y}_{0,15} \mathrm{O}_{3-8}$ (com $\mathrm{ZrO}_{2}: 8 \%$ mol de $\mathrm{Y}_{2} \mathrm{O}_{3}$ ) por mistura de óxidos (a), (b), (c) e submetidos a moagem em moinho atritor (d), (e) e (f).

$\mathrm{O}$ composto $\mathrm{BaZr}_{0,85} \mathrm{Y}_{0,15} \mathrm{O}_{3-\delta}$, preparado com pós submetidos a moagem em moinho atritor, apresenta uma fração média pequena de partículas de tamanho $1 \mu \mathrm{m}$ em relação aos outros compostos, que pode ter gerado uma grande quantidade de aglomerados que foram sinterizados isoladamente, como é possível observar nas micrografias (d) e (e).

\section{A.2 Eletrodo (catodo)}

\section{Difração de raios $\mathrm{X}$}

A Figura 22 mostra um difratograma de raios $X$ do composto $\mathrm{La}_{0,6} \mathrm{Ca}_{0,4} \mathrm{Fe}_{0,8} \mathrm{Co}_{0,2} \mathrm{O}_{3-\delta}$ utilizado como catodo da célula a combustível. 


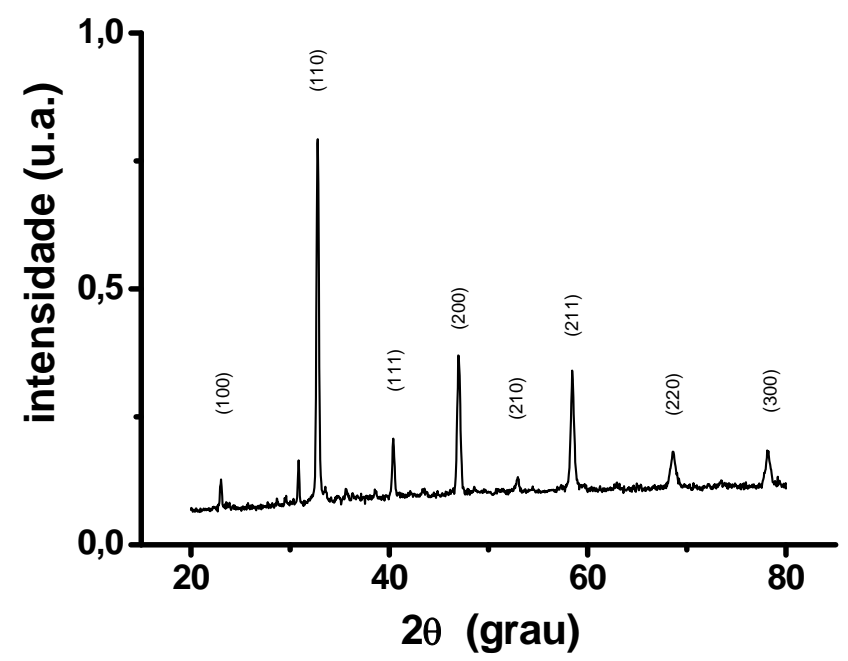

Figura 22: Difratograma de raios $X$ do composto $\mathrm{La}_{0,6} \mathrm{Ca}_{0,4} \mathrm{Fe}_{0,8} \mathrm{Co}_{0,2} \mathrm{O}_{3-\delta}$ preparado por mistura de óxidos.

\section{Distribuição de tamanho de partícula}

A Figura 23 mostra a distribuição de tamanho de partícula do composto $\mathrm{La}_{0,6} \mathrm{Ca}_{0,4} \mathrm{Fe}_{0,8} \mathrm{Co}_{0,2} \mathrm{O}_{3-\delta}$ preparado por mistura de óxidos.

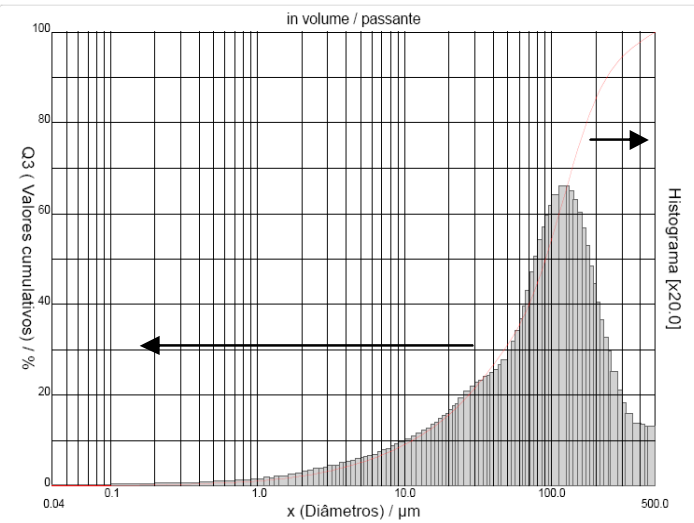

Figura 23: Distribuição de tamanho de partícula de $\mathrm{La}_{0,6} \mathrm{Ca}_{0,4} \mathrm{Fe}_{0,8} \mathrm{Co}_{0,2} \mathrm{O}_{3-\delta}$ preparado por mistura de óxidos.

A distribuição do composto preparado por mistura de óxidos é monomodal com diâmetro médio $110 \mu \mathrm{m}$. O tamanho de partícula do eletrodo e a porosidade são parâmetros importantes para a interação na interface eletrólito/eletrodo, local 
onde ocorrem as reações eletroquímicas e, por esse motivo, também é adicionado o material do próprio eletrólito sólido para aumentar o número de contatos e favorecer as reações eletroquímicas.

\section{B. Testes operacionais}

São apresentados os resultados de medidas de potencial de circuito aberto (OCV) e de potencial sob carga (curvas IV) de seis tipos de células a combustível, todas operando com combustível metano e/ou hidrogênio ou $4 \% \mathrm{H}_{2}+96 \% \mathrm{~N}_{2}$ : LCFC/BaCe $e_{0,8} \mathrm{Gdd}_{0,2} \mathrm{O}_{3-\delta} / \mathrm{Pt}, \quad \mathrm{Pt} / \mathrm{BaCe}_{0,8} \mathrm{Gd}_{0,2} \mathrm{O}_{3-\delta} / \mathrm{Pt}, \quad \mathrm{LCFC} / \mathrm{BaZr}_{0,92} \mathrm{Y}_{0,08} \mathrm{O}_{3-\delta} / \mathrm{Pt} \quad$ e $\mathrm{LCFC} / \mathrm{BaZr}_{0,85} \mathrm{Y}_{0,15} \mathrm{O}_{3-\delta} / \mathrm{Pt}$.

\section{Células $\mathrm{LCFC} / \mathrm{BaCe}_{0,8} \mathrm{Gd}_{0,2} \mathrm{O}_{3-\delta} / \mathrm{Pt}$ e $\mathrm{Pt} / \mathrm{BaCe}_{0,8} \mathrm{Gd}_{0,2} \mathrm{O}_{3-\delta} / \mathrm{Pt}$}

\section{OCV - metano}

A Figura 24 mostra a evolução com o tempo do potencial de circuito aberto da célula $\mathrm{LCFC} / \mathrm{BaCe}_{0,8} \mathrm{Gd}_{0,2} \mathrm{O}_{3-\delta} / \mathrm{Pt}$ na faixa de temperatura 25-600 ${ }^{\circ} \mathrm{C}$.

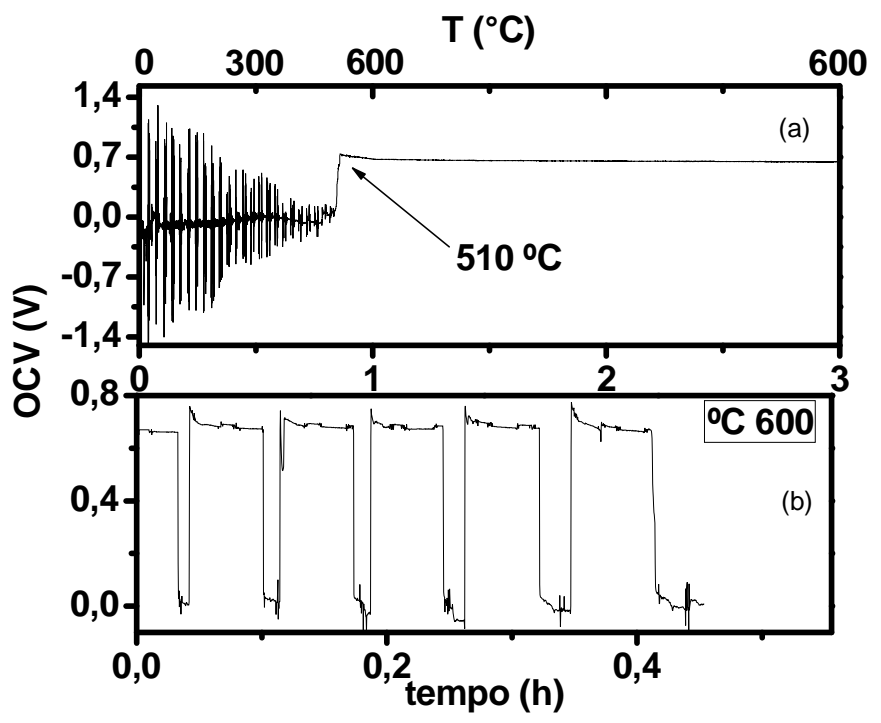

Figura 24: (a) Potencial de circuito aberto em função do tempo de operação da célula $\mathrm{LCFC} / \mathrm{BaCe}_{0,8} \mathrm{Gd}_{0,2} \mathrm{O}_{3-\delta} / \mathrm{Pt}$ na faixa de temperatura 25-600 ${ }^{\circ} \mathrm{C}$ com metano; (b) teste liga-desliga suprimento de metano.

A Figura 24a mostra que o ruído do sinal diminui com o aumento da temperatura e a $510{ }^{\circ} \mathrm{C}$ há um aumento no valor do potencial devido ao 
craqueamento da molécula do metano com formação de hidrogênio e produção de prótons para o transporte de carga. Esta é a temperatura mínima de operação desta célula com metano. A Figura 24b mostra a resposta relativamente rápida da célula $(1,1 \mathrm{~s})$ à injeção de metano, com manutenção do valor do potencial em $0,73 \mathrm{~V}$.

Este é o primeiro resultado importante deste trabalho: a determinação da temperatura de início da produção de hidrogênio a partir do metano na superfície da célula: $\sim 510^{\circ} \mathrm{C}$.

A Figura 25 mostra o potencial de circuito aberto em função do tempo com a diminuição da temperatura a $10{ }^{\circ} \mathrm{C} / \mathrm{min}$ de 600 até $500{ }^{\circ} \mathrm{C}$ em várias etapas.
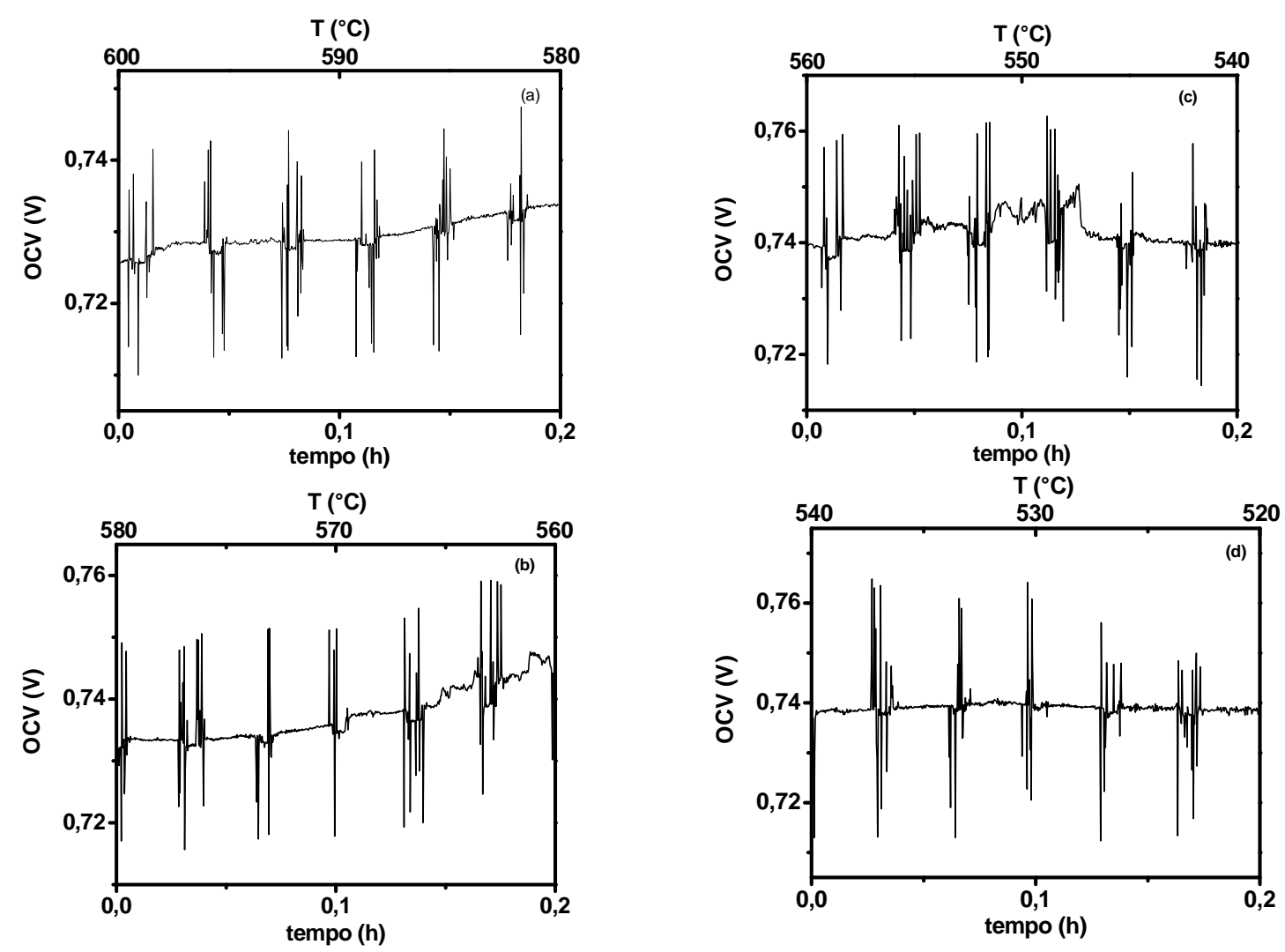


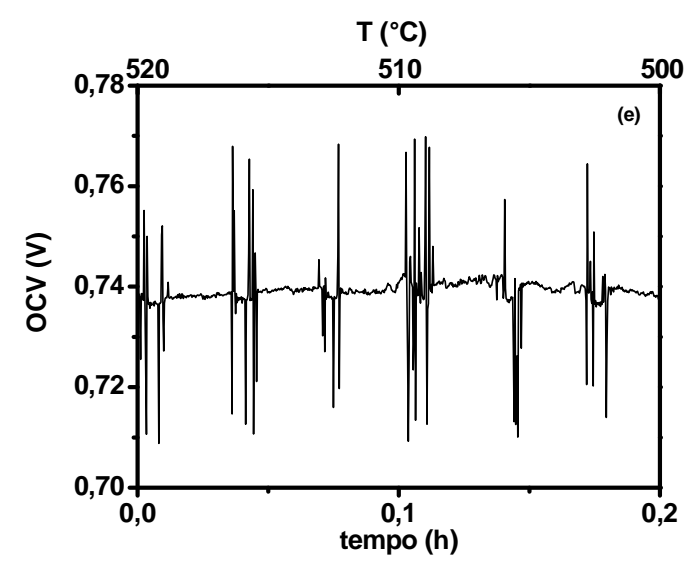

Figura 25: Potencial de circuito aberto da célula $\mathrm{LCFC} / \mathrm{BaCe}_{0,8} \mathrm{Gd}_{0,2} \mathrm{O}_{3-\delta} / \mathrm{Pt}$ com combustível metano nas faixas de temperatura de 500 a $600 \stackrel{\circ}{\circ} \mathrm{C}$ de vinte em vinte graus.

A Figura 25a mostra que há um pequeno aumento do potencial inicial $(0,72$ V); a Figura $25 \mathrm{~b}$, um contínuo aumento do potencial até $0,75 \mathrm{~V}$; a Figura $25 \mathrm{c}$ mostra um aumento do ruído no sinal e picos no potencial de 0,74 a $0,75 \mathrm{~V}$, com a estabilização em $0,74 \mathrm{~V}$; a Figura 25d mostra um aumento do ruído no sinal e o potencial estabilizado em $0,74 \mathrm{~V}$; a Figura 25e mostra o potencial estabilizado em 0,74 V. Essa variação no potencial da célula deve ser devida à variação da pressão do metano na superfície do anodo, com a diminuição da temperatura. Os sinais carga-descarga são periódicos e provavelmente devidos a acúmulo de carga produzidas eletrostaticamente na superfície da célula (anodo).

A Figura 26 mostra o potencial de circuito aberto em função do tempo na temperatura de $600{ }^{\circ} \mathrm{C}$. 


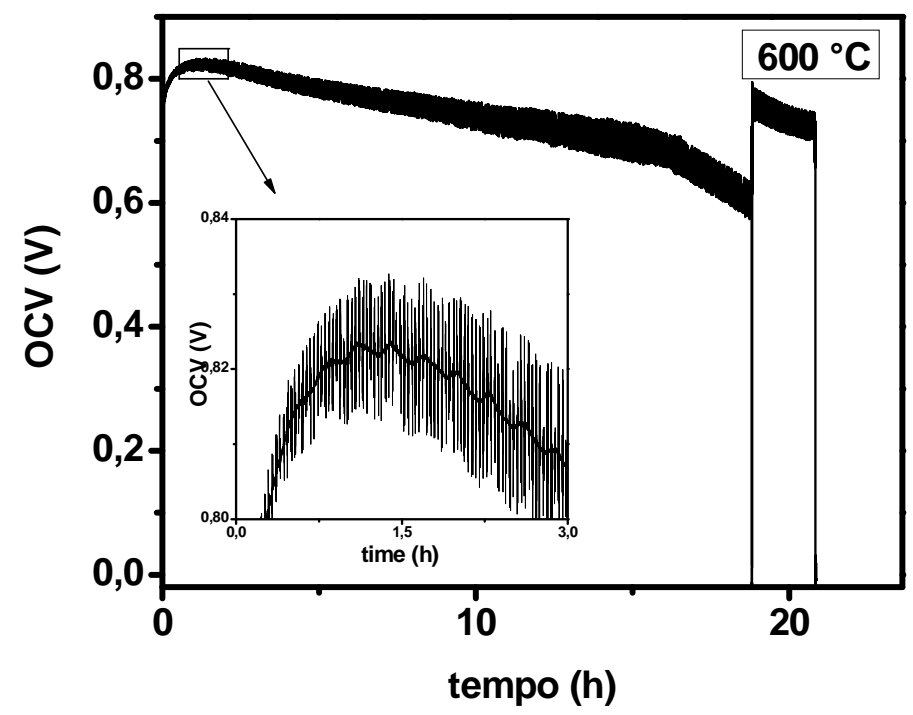

Figura 26: Potencial de circuito aberto da célula $\mathrm{LCFC} / \mathrm{BaCe}_{0,8} \mathrm{Gd}_{0,2} \mathrm{O}_{3-\delta} / \mathrm{Pt}$ em 600 o $\mathrm{C}$, com potencial máximo de $0,82 \mathrm{~V}$, operando com metano.

Um teste por um período longo, logo após o teste com hidrogênio, apresentou potencial máximo de $0,82 \mathrm{~V}$, aumento de ruído do sinal e diminuição do potencial, devido à falta de controle de fluxo do gás. Isto mostra que o fluxo de combustível é um parâmetro importante no controle do funcionamento da célula a combustível operando com metano.

$\mathrm{O}$ teste da célula $\mathrm{Pt} / \mathrm{BaCe}_{0,8} \mathrm{Gd}_{0,2} \mathrm{O}_{3-\delta} / \mathrm{Pt}$ foi feito utilizando selante de vidro nióbio-fosfato. O procedimento experimental foi elevar a temperatura a $10 \stackrel{\circ}{\circ} / \mathrm{min}$ de $25{ }^{\circ} \mathrm{C}$ até $930 \stackrel{\circ}{\circ} / 5$ min para cristalização do vidro, e diminuir até $300 \stackrel{\circ}{\mathrm{C}}$ para a injeção de gás, seguida da elevação da temperatura até $600{ }^{\circ} \mathrm{C}$ para as medidas de potencial de circuito aberto e de curvas IV.

A Figura 27 mostra os valores de potencial de circuito aberto em função do tempo em operação com metano na faixa 300 - $600{ }^{\circ} \mathrm{C}$ e a $600 \stackrel{\circ}{\circ} \mathrm{C}$. 


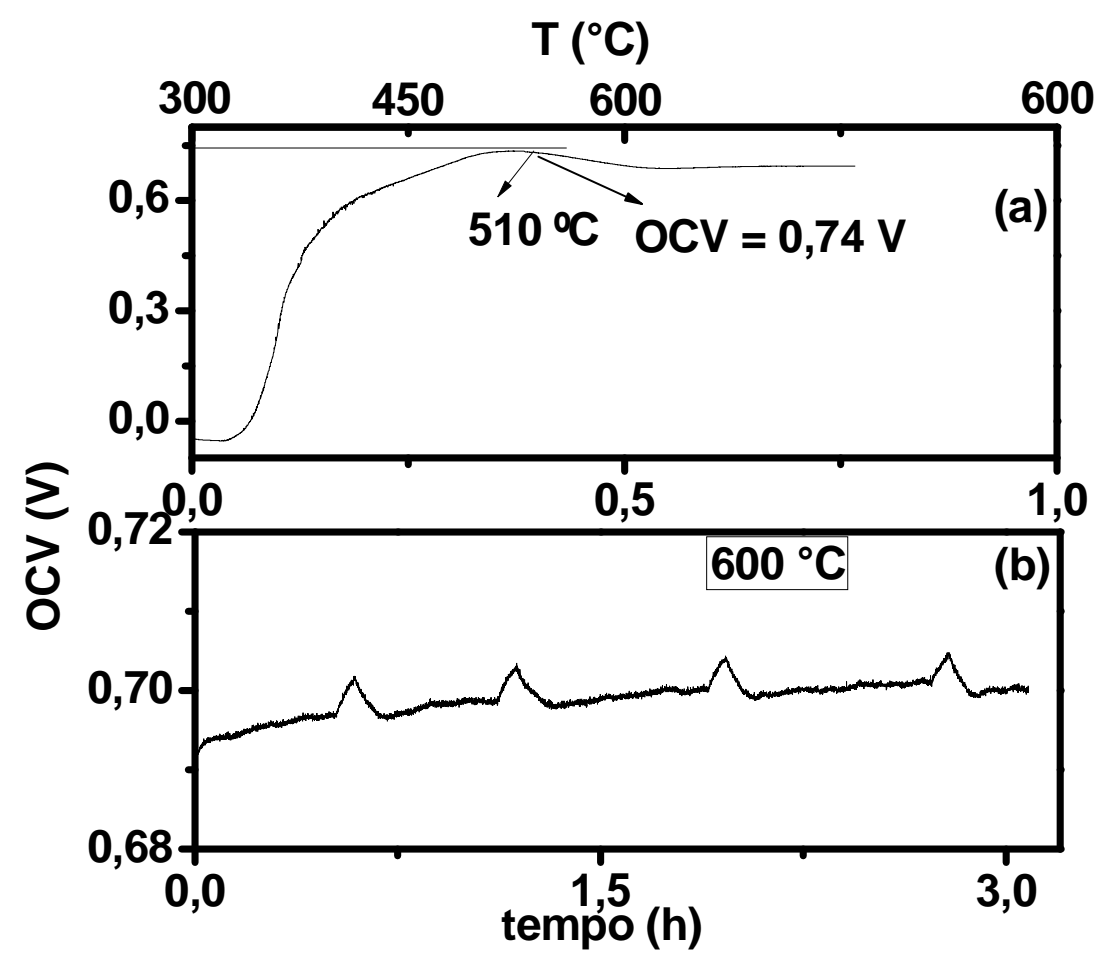

Figura 27: Potencial de circuito aberto da célula $\mathrm{Pt} / \mathrm{BaCe}_{0,8} \mathrm{Gd}_{0,2} \mathrm{O}_{3-\delta} / \mathrm{Pt}$ de $300 \mathrm{a}$ $600 \stackrel{\circ}{\circ}$ operando com metano (a) e a $600 \stackrel{\circ}{ } \mathrm{C}$ operando com metano (b).

Há um pico de 0,74 $\mathrm{V}$ no valor do potencial em $\sim 515 \stackrel{\circ}{\mathrm{C}}$ ao aumentar a temperatura da célula de 300 a $600 \stackrel{\circ}{\circ}$ com injeção de metano. Após a operação da célula é possível observar o acúmulo de carbono adsorvido na platina.

\section{OCV - hidrogênio}

A Figura 28 mostra o potencial de circuito aberto da célula LCFC/ $\mathrm{BaCe}_{0,8} \mathrm{Gd}_{0,2} \mathrm{O}_{3-\delta} / \mathrm{Pt}$ operando com hidrogênio a $600 \stackrel{\circ}{ } \mathrm{C}$.

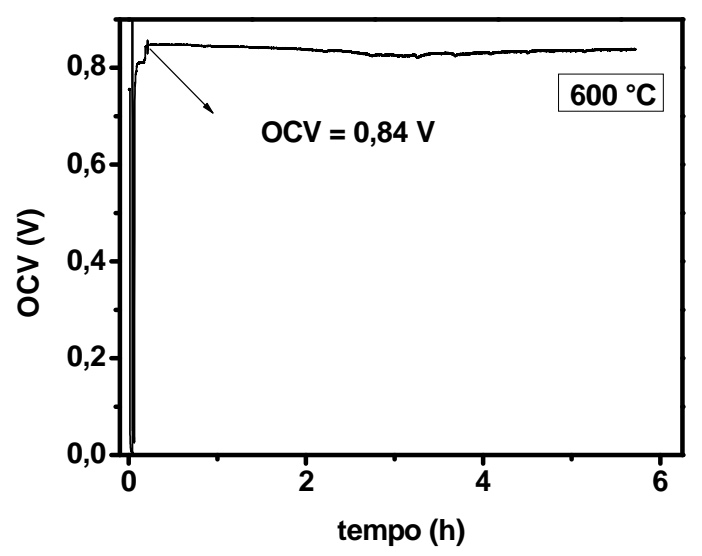


Figura 28: Potencial de circuito aberto da célula LCFC/ $\mathrm{BaCe}_{0,8} \mathrm{Gd}_{0,2} \mathrm{O}_{3-\delta} / \mathrm{Pt}$ a 600 oC operando com combustível hidrogênio, em função do tempo de operação.

$\mathrm{O}$ potencial da célula estabilizou em $0,84 \mathrm{~V}$ por mais de $5 \mathrm{~h}$ com combustível hidrogênio. Este é um bom valor de potencial para uma célula a combustível de óxido sólido protônica, se comparado com o valor 1,5 V, obtido na SOFC de $\mathrm{ZrO}_{2}: 8$ mol\% $\mathrm{Y}_{2} \mathrm{O}_{3}$ operando a $1000 \stackrel{\circ}{\circ}[80]$.

A Figura 29 mostra o potencial de circuito aberto em função do tempo de operação da célula de $\mathrm{Pt} / \mathrm{BaCe}_{0,8} \mathrm{Gd}_{0,2} \mathrm{O}_{3-\delta} / \mathrm{Pt} \operatorname{com} 4 \% \mathrm{H}_{2}+96 \% \mathrm{~N}_{2}$ de 300 a 600 $\stackrel{\circ}{ } \mathrm{C}$ e a $600 \stackrel{\circ}{\circ}$.

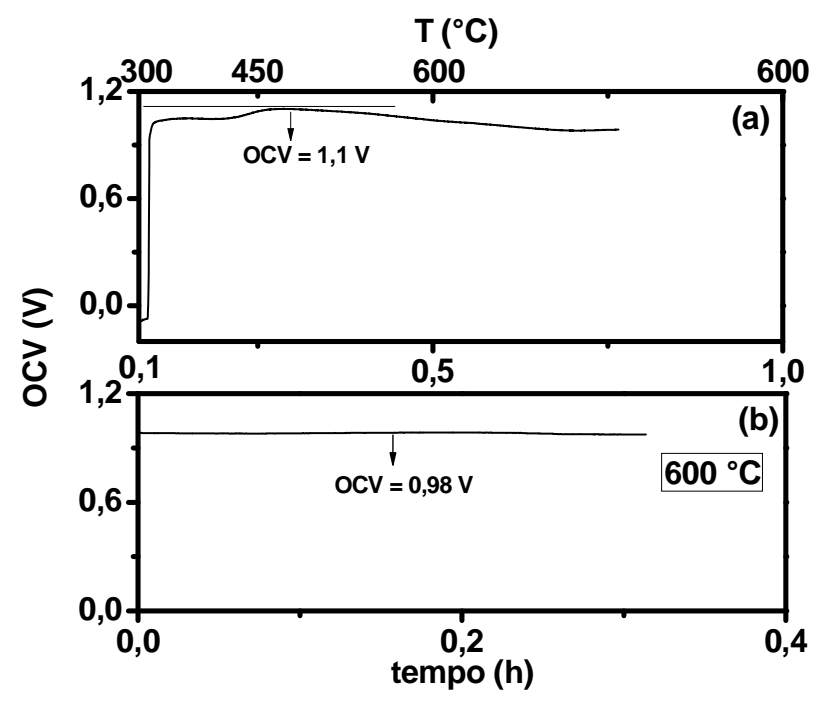

Figura 29: Potencial de circuito aberto da célula $\mathrm{Pt} / \mathrm{BaCe}_{0,8} \mathrm{Gd}_{0,2} \mathrm{O}_{3-\delta} / \mathrm{Pt}$ de $300 \stackrel{\circ}{\circ} \mathrm{a}$ $600 \stackrel{\circ}{\circ}$ operando com $4 \% \mathrm{H}_{2}+96 \% \mathrm{~N}_{2}$ (a) e a $600 \stackrel{\circ}{\circ} \mathrm{C}$ (b).

Há um pico de potencial em $\sim 1,1 \mathrm{~V}$ próximo de $350{ }^{\circ} \mathrm{C}(\mathrm{t}=0,3 \mathrm{~h})$ de $300 \mathrm{a}$ $600{ }^{\circ} \mathrm{C}$ e pequena variação do potencial ao longo do tempo em $600{ }^{\circ} \mathrm{C}$ operando com $4 \% \mathrm{H}_{2}+96 \% \mathrm{~N}_{2}$.

\section{Curvas IV - metano e $4 \% \mathrm{H}_{2}+96 \% \mathrm{~N}_{2}$}

A Figura 30 mostra os valores do potencial em função da corrente aplicada na célula LCFC/BaCe $e_{0,8} \mathrm{Gd}_{0,2} \mathrm{O}_{3-\delta} / \mathrm{Pt}$ operando com metano a 600, 580, 560, 540, 520 e $500{ }^{\circ} \mathrm{C}$. 


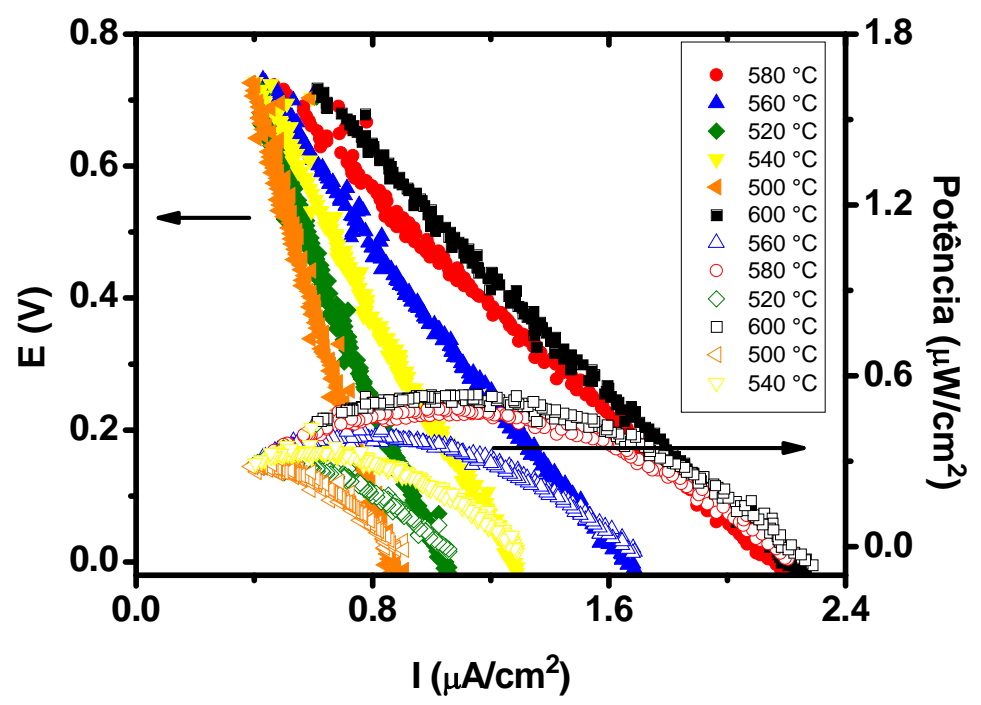

Figura 30: Potencial sob solicitação de carga da célula $\mathrm{LCFC} / \mathrm{BaCe}_{0,8} \mathrm{Gd}_{0,2} \mathrm{O}_{3-\delta} / \mathrm{Pt}$ a $600,580,560,540,520$ e $500 \stackrel{\circ}{C}$, operando com metano.

Quanto maior a temperatura de operação, maior a potência retirada da célula $\mathrm{LCFC} / \mathrm{BaCe}_{0,8} \mathrm{Gd}_{0,2} \mathrm{O}_{3-\delta} / \mathrm{Pt}$ operando com gás metano no anodo e ar no catodo. Os valores estão na faixa $0,3-0,6 \mu \mathrm{W} / \mathrm{cm}^{2}$ de 500 a $600{ }^{\circ} \mathrm{C}$.

A Figura 31 mostra os valores do potencial em função da corrente aplicada na célula $\mathrm{LCFC} / \mathrm{BaCe}_{0,8} \mathrm{Gdd}_{0,2} \mathrm{O}_{3-\delta} / \mathrm{Pt}$ em duas situações: operando com metano e com hidrogênio a $600^{\circ} \mathrm{C}$.

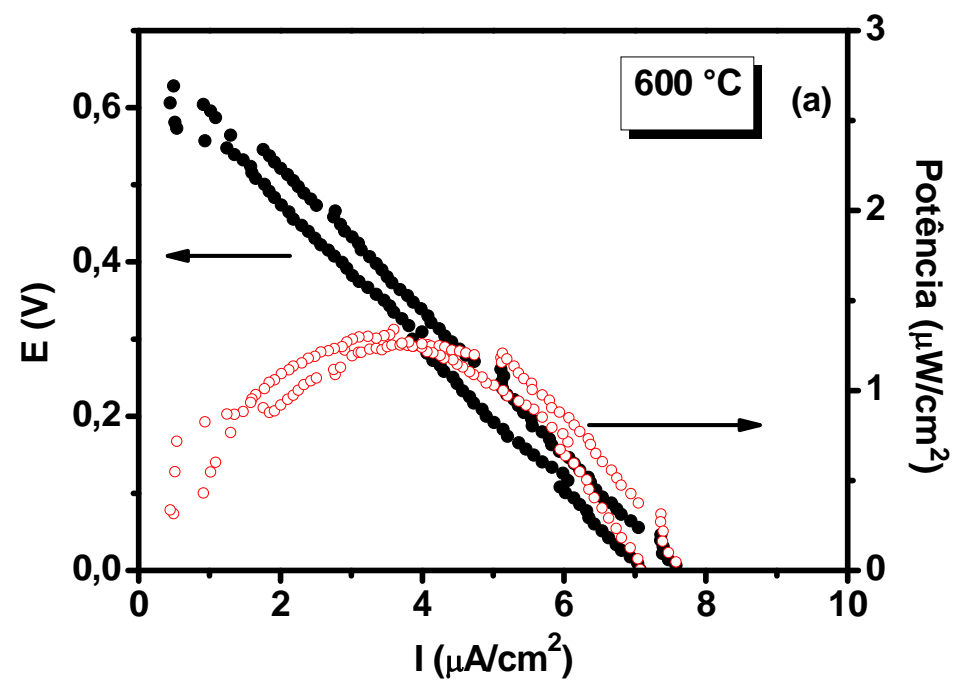




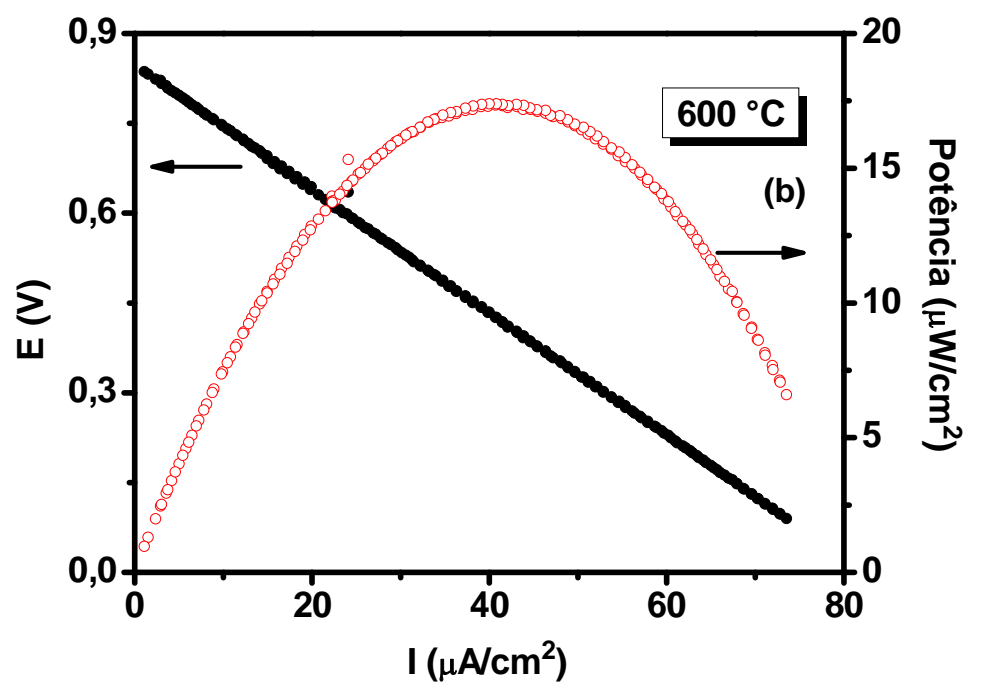

Figura 31: Potencial sob solicitação de carga a $600{ }^{\circ} \mathrm{C}$ da célula LCFC/ $\mathrm{BaCe}_{0,8} \mathrm{Gd}_{0,2} \mathrm{O}_{3-\delta} / \mathrm{Pt}$ operando com metano (a) e com hidrogênio (b).

Este resultado é importante, pois mostra que mesmo com um potencial de $0,74 \mathrm{~V}$ com metano e $0,84 \mathrm{~V}$ com hidrogênio (Figuras 24 e 28), a potência da célula é relativamente baixa $\left(1,3 \mu \mathrm{W} / \mathrm{cm}^{2}\right.$ sob metano e $17 \mu \mathrm{W} / \mathrm{cm}^{2}$ sob hidrogênio), sendo que o teste com metano foi feito posteriormente ao teste com hidrogênio. $O$ aumento da potência da célula poderá ser obtido com a melhoria na preparação de condutores protônicos mais densos e na forma de filme fino para diminuir o valor da queda ohmica, em uma célula suportada no anodo, por exemplo, por causa da baixa resistência mecânica dos condutores protônicos à base de cerato e zirconato de bário.

Os desvios em algumas partes da reta são provavelmente causados por reações tipo carga-descarga, já comentados anteriormente na análise de potencial de circuito aberto.

A Figura 32 mostra o valor do potencial em função da corrente aplicada na célula $\mathrm{Pt} / \mathrm{BaCe}_{0,8} \mathrm{Gd}_{0,2} \mathrm{O}_{3-\delta} / \mathrm{Pt}$ com combustível metano. 


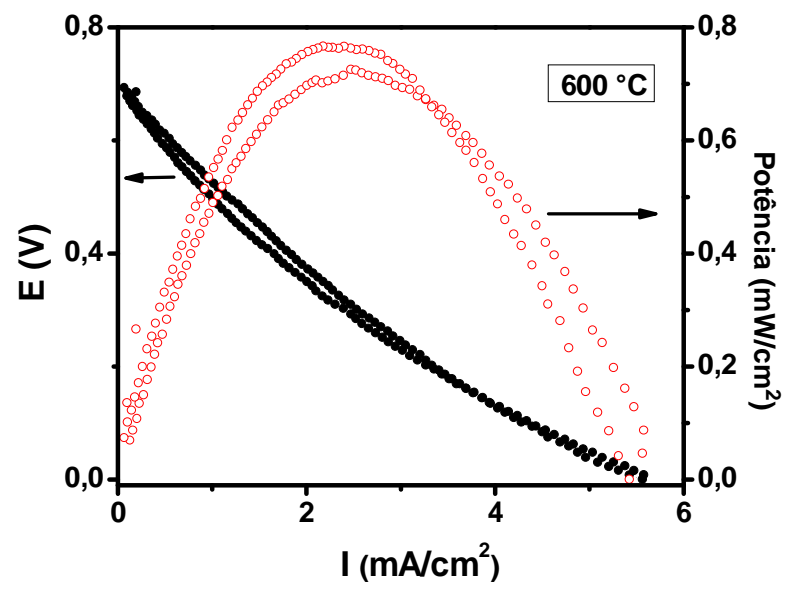

Figura 32: Potencial sob solicitação de carga a $600{ }^{\circ} \mathrm{C}$ da célula $\mathrm{Pt} / \mathrm{BaCe}_{0,8} \mathrm{Gd}_{0,2} \mathrm{O}_{3-\delta} / \mathrm{Pt}$ operando com metano.

O valor de potência da célula, $0,7 \mathrm{~mW} / \mathrm{cm}^{2}$, é alto se comparado com os obtidos anteriormente.

A Figura 33 mostra o valor do potencial em função da corrente aplicada na célula $\mathrm{Pt} / \mathrm{BaCe}_{0,8} \mathrm{Gd}_{0,2} \mathrm{O}_{3-\delta} / \mathrm{Pt} \operatorname{com} 4 \% \mathrm{H}_{2}+96 \% \mathrm{~N}_{2}$ a $600{ }^{\circ} \mathrm{C}$.

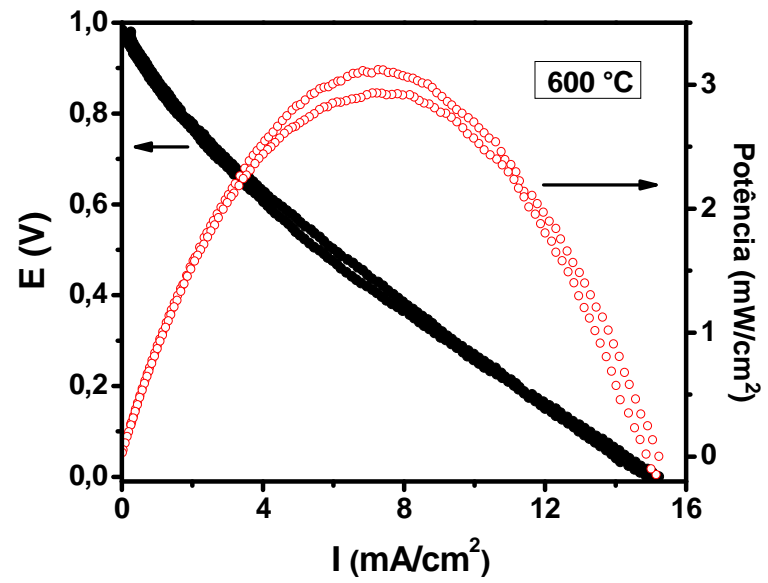

Figura 33: Potencial sob solicitação de carga a $600{ }^{\circ} \mathrm{C}$ da célula $\mathrm{Pt} / \mathrm{BaCe}_{0,8} \mathrm{Gd}_{0,2} \mathrm{O}_{3-\delta} / \mathrm{Pt}$ operando com $4 \% \mathrm{H}_{2}+96 \% \mathrm{~N}_{2}$.

É o mais alto valor de potência, comparado com os resultados obtidos operando com metano e $4 \% \mathrm{H}_{2}+96 \% \mathrm{~N}_{2}$.

\section{Célula LCFC/BaZr ${ }_{0,92} \mathrm{Y}_{0,08} \mathrm{O}_{3-\delta} / \mathrm{Pt}$}




\section{OCV - metano}

A Figura 34 mostra o potencial de circuito aberto da célula LCFC/BaZr ${ }_{0,92} \mathrm{Y}_{0,08} \mathrm{O}_{3-\delta} / \mathrm{Pt}$ em função do tempo, operando a $600{ }^{\circ} \mathrm{C}$.

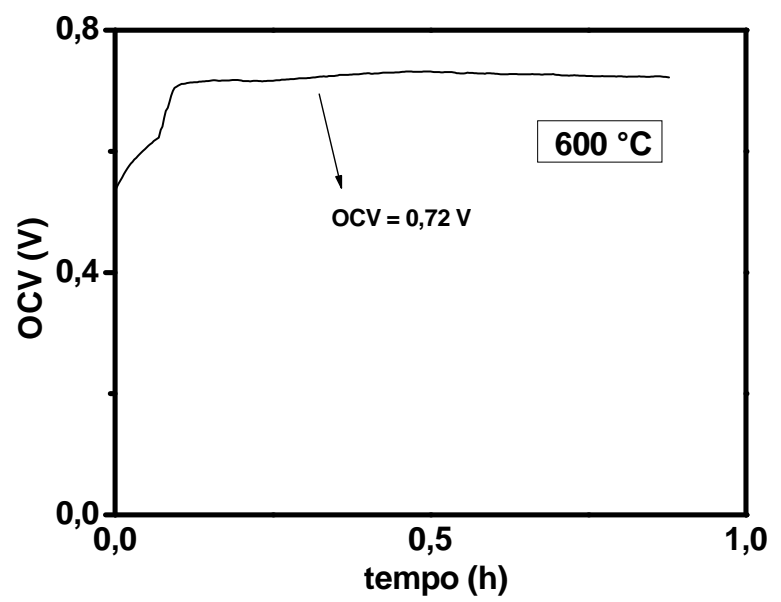

Figura 34: Potencial de circuito aberto da célula $L C F C / \mathrm{BaZr}_{0,92} \mathrm{Y}_{0,08} \mathrm{O}_{3-\delta} / \mathrm{Pt}$ a $600{ }^{\circ} \mathrm{C}$ operando com combustível metano, em função do tempo de operação.

O potencial de circuito aberto a $600{ }^{\circ} \mathrm{C}$ se manteve estável em $0,72 \mathrm{~V}$, operando com metano. Porém, sob hidrogênio, não foi estável, talvez porque esta célula foi construída usando tijolo refratário como câmara, não sendo a selagem adequada para impedir a difusão de $\mathrm{H}_{2}$.

As Figuras 35 e 36 mostram o potencial de circuito aberto da célula $\mathrm{LCFC} / \mathrm{BaZr}_{0,92} \mathrm{Y}_{0,08} \mathrm{O}_{3-\delta} / \mathrm{Pt}$ (eletrólito preparado com pós cominuídos em moinho atritor) em função do tempo, na faixa de temperatura de $300 \stackrel{\circ}{\mathrm{C}}$ a $600{ }^{\circ} \mathrm{C}$ com taxa de aquecimento $10^{\circ} \mathrm{C} / \mathrm{min}$, e o potencial de circuito aberto em função do tempo na temperatura de $600^{\circ} \mathrm{C}$. 


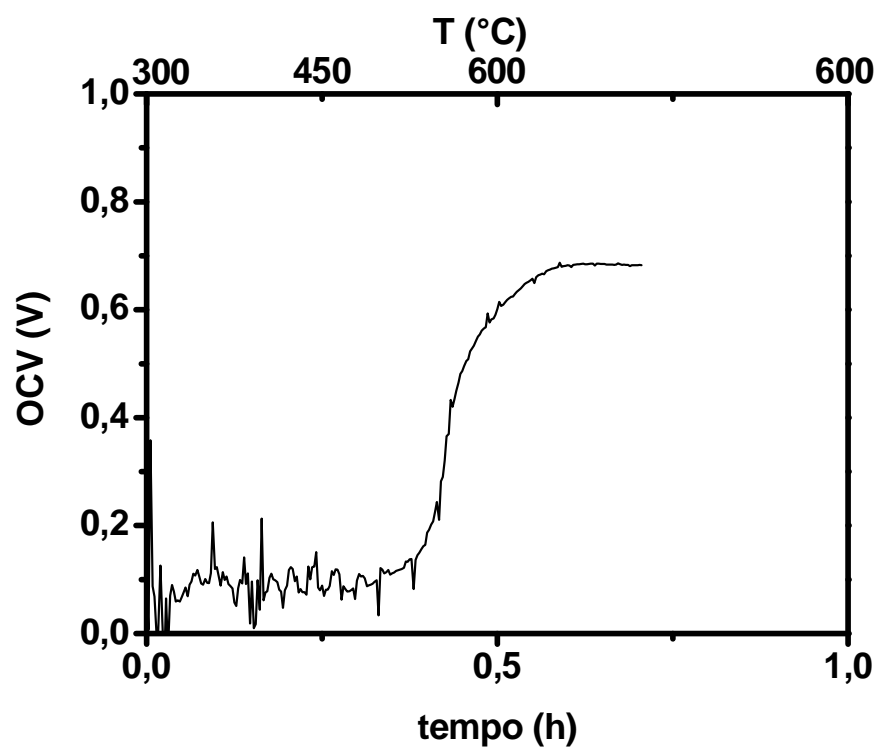

Figura 35: Potencial de circuito aberto da célula LCFC/BaZr $r_{0,92} \mathrm{Y}_{0,08} \mathrm{O}_{3-\delta} / \mathrm{Pt}$ de $300 \mathrm{a}$ $600 \stackrel{\circ}{ }{ }^{\circ}$ operando com combustível metano, em função do tempo de operação.

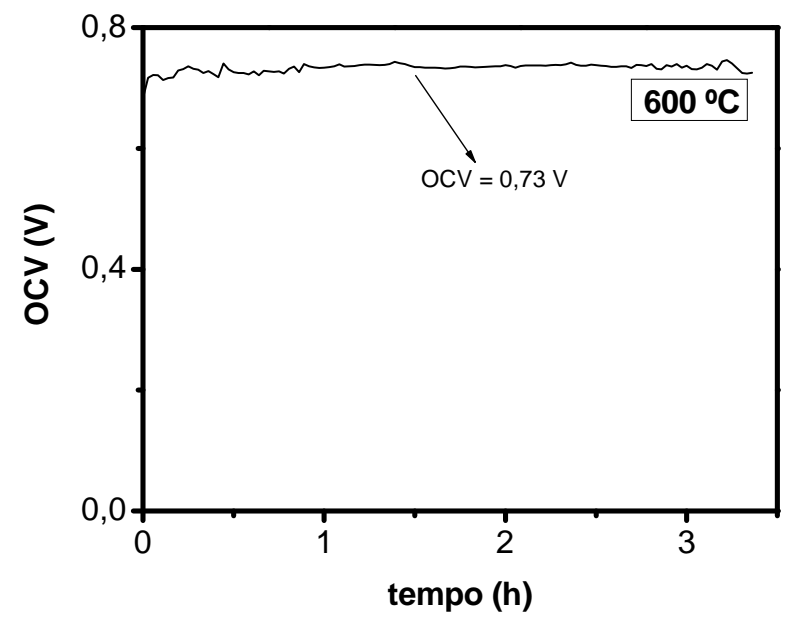

Figura 36: Potencial de circuito aberto da célula LCFC/BaZr $r_{0,92} \mathrm{Y}_{0,08} \mathrm{O}_{3-\delta} / \mathrm{Pt}$ a $600{ }^{\circ} \mathrm{C}$ operando com combustível metano, em função do tempo de operação.

A Figura 35 mostra o inicio do craqueamento do metano na faixa de temperatura de 300 a $600{ }^{\circ} \mathrm{C}$. Mas, ao contrário das outras células, o potencial não atingiu o máximo a uma temperatura de $\sim 515{ }^{\circ} \mathrm{C}$, mantendo-se em constante elevação até se estabilizar em $600{ }^{\circ} \mathrm{C}$, evidenciando o diferente tipo de reação catalítica na superfície desta célula, operando com metano.

A figura 36 mostra que o potencial de circuito aberto em função do tempo se manteve estável entre 0,72 a $0,73 \vee$ por mais de $3 \mathrm{~h}$. 


\section{$\mathrm{OCV}-4 \% \mathrm{H}_{2}+96 \% \mathrm{~N}_{2}$}

A Figura 37 mostra 0 potencial de circuito aberto da célula $\mathrm{LCFC} / \mathrm{BaZr}_{0,92} \mathrm{Y}_{0,08} \mathrm{O}_{3-\delta} / \mathrm{Pt}$ (eletrólito sólido preparado com pó submetido a moinho atritor) em função do tempo, na faixa de temperatura de $300 \stackrel{\circ}{\circ} \mathrm{C}$ a $600 \stackrel{\circ}{\circ} \mathrm{C}$ com taxa de aquecimento de $10^{\circ} \mathrm{C} / \mathrm{min}$.

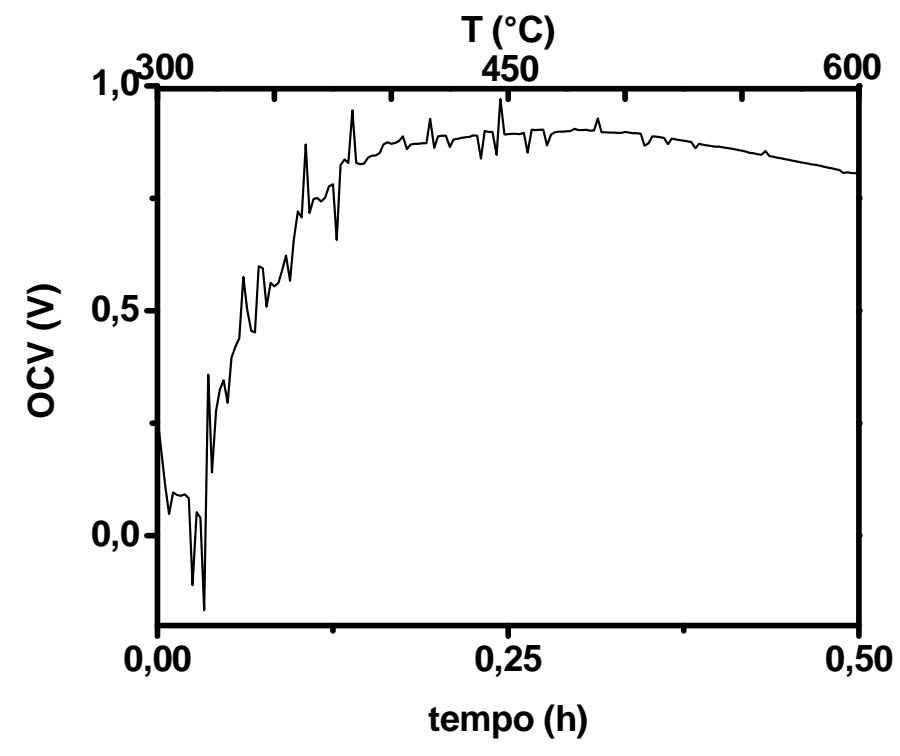

Figura 37: Potencial de circuito aberto da célula $\mathrm{LCFC} / \mathrm{BaZr}_{0,92} \mathrm{Y}_{0,08} \mathrm{O}_{3-\delta} / \mathrm{Pt}$ (eletrólito sólido preparado por mistura de óxidos em moinho atritor) em função do tempo de operação, operando com combustível $4 \% \mathrm{H}_{2}+96 \% \mathrm{~N}_{2}$ na faixa de temperatura $300-600 \stackrel{\circ}{\circ}$.

É possível observar a evolução do potencial com o valor máximo em 515 ${ }^{\circ} \mathrm{C}$, decaindo após atingir esta temperatura.

A Figura 38 mostra 0 potencial de circuito aberto da célula $\mathrm{LCFC} / \mathrm{BaZr}_{0,92} \mathrm{Y}_{0,08} \mathrm{O}_{3-\delta} / \mathrm{Pt}$ (eletrólito sólido preparado com pó submetido a moinho atritor) em função do tempo, na temperatura de a $600 \stackrel{\circ}{\circ}$. 


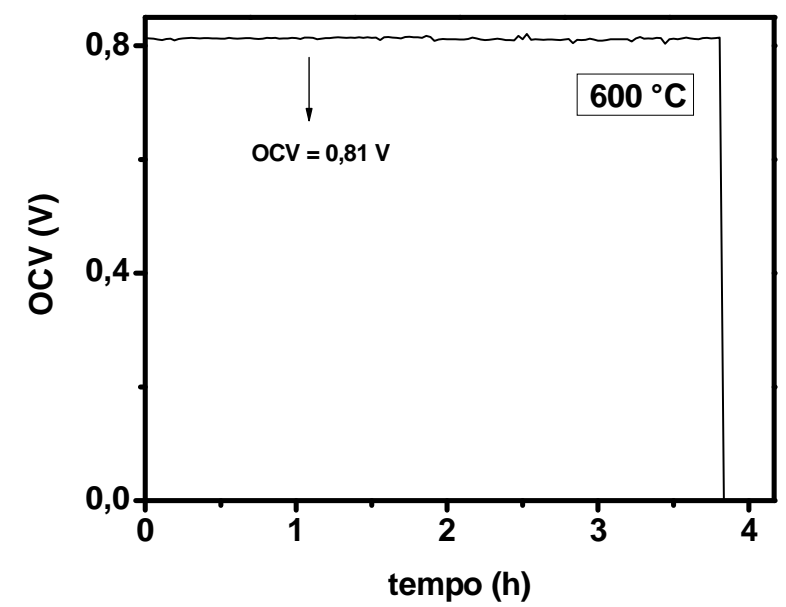

Figura 38: Potencial de circuito aberto em função do tempo de operação da célula $\mathrm{LCFC} / \mathrm{BaZr}_{0,92} \mathrm{Y}_{0,08} \mathrm{O}_{3-\delta} / \mathrm{Pt}$ (eletrólito sólido preparado por mistura de óxidos em moinho atritor) com combustível $4 \% \mathrm{H}_{2}+96 \% \mathrm{~N}_{2}$ a $600 \stackrel{\circ}{\circ}$.

O potencial de circuito aberto se manteve estável em $0,81 \mathrm{~V}$ por aproximadamente 4 h. $\mathrm{O}$ potencial das células operando com $4 \% \mathrm{H}_{2}+96 \% \mathrm{~N}_{2}$ depende muito da selagem, pois é alto o fluxo do combustível necessário para a produção de prótons e elétrons no anodo, devido à baixa concentração de hidrogênio (4\%), fazendo com que o tempo de permanência do gás na câmara não seja suficiente para promover a reação eletroquímica, já que vazamentos são freqüentes com uma pressão maior.

\section{Curvas IV - metano e $4 \% \mathrm{H}_{2}+96 \% \mathrm{~N}_{2}$}

A Figura 39 mostra o valor do potencial em função da corrente aplicada na célula LCFC/BaZr ${ }_{0,92} \mathrm{Y}_{0,08} \mathrm{O}_{3-\delta} / \mathrm{Pt}$ operando com combustível metano. 


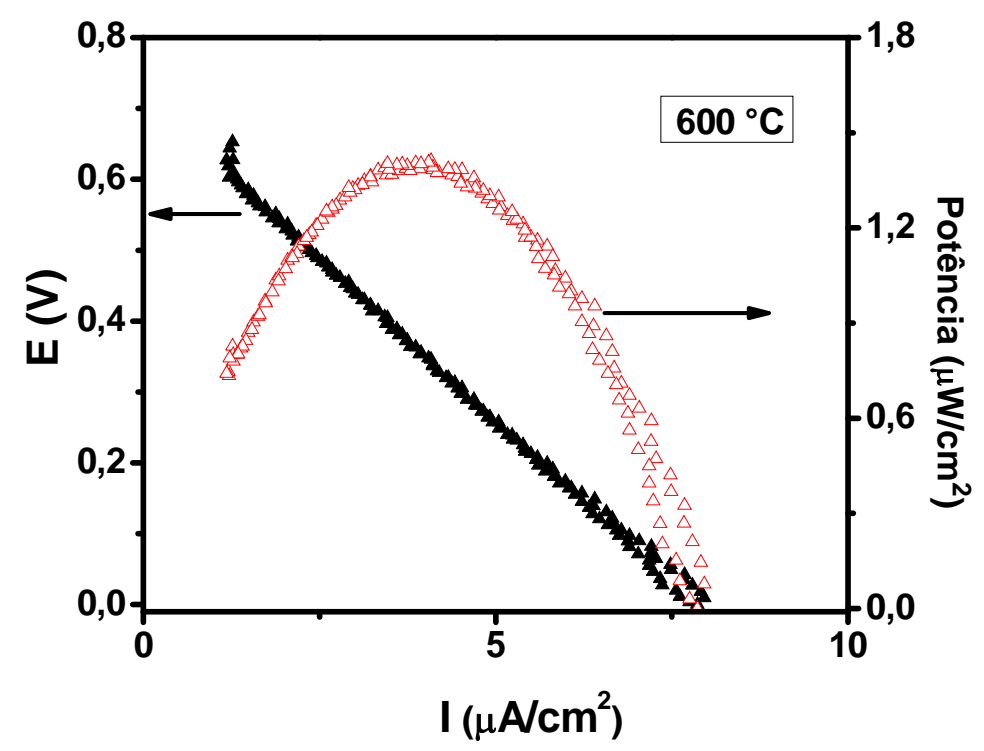

Figura 39: Potencial sob solicitação de carga da célula $\mathrm{LCFC} / \mathrm{BaZr}_{0,92} \mathrm{Y}_{0,08} \mathrm{O}_{3-\delta} / \mathrm{Pt}$ a $600{ }^{\circ} \mathrm{C}$ com combustível metano (eletrólito sólido preparado por mistura de óxidos).

O valor de potência foi o melhor para as células operando com metano com eletrólitos de $\mathrm{BaZr}_{0,92} \mathrm{Y}_{0,08} \mathrm{O}_{3-\delta}$ mas, da mesma forma que está célula apresentou instabilidade na medida de potencial de circuito aberto, também não pode ser medida utilizando-se $4 \% \mathrm{H}_{2}+96 \% \mathrm{~N}_{2}$. Outra hipótese é que com o fluxo alto e a alta porosidade, o gás penetre pelo eletrólito até o catodo curto-circuitando a célula.

As figuras 40 e 41 mostram valores do potencial em função da corrente aplicada na célula LCFC/BaZro, $\mathrm{Br}_{0,08} \mathrm{Y}_{3-\delta} / \mathrm{Pt}$ (eletrólito sólido preparado por moinho atritor) com combustível metano e $4 \% \mathrm{H}_{2}+96 \% \mathrm{~N}_{2}$ respectivamente. 


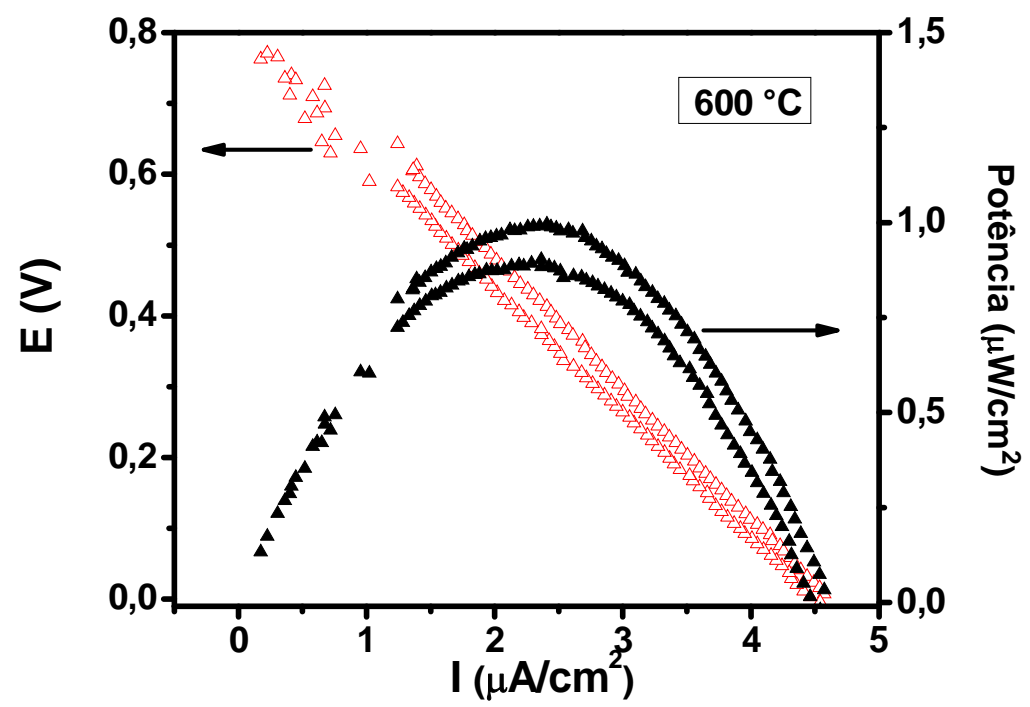

Figura 40: Potencial sob solicitação de carga da célula LCFC/BaZro, $\mathrm{Zr}_{0,2} \mathrm{Y}_{0,08} \mathrm{O}_{3-\delta} / \mathrm{Pt}$ a $600{ }^{\circ} \mathrm{C}$ com combustível metano.

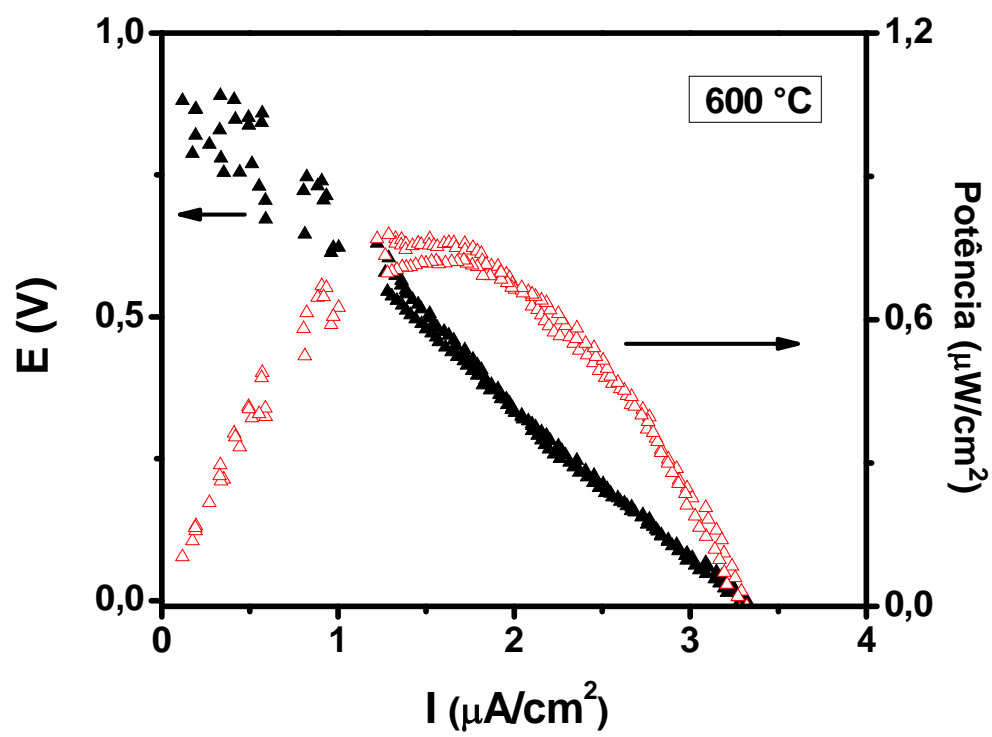

Figura 41: Potencial sob solicitação de carga da célula LCFC/BaZr ${ }_{0,92} \mathrm{Y}_{0,08} \mathrm{O}_{3-\delta} / \mathrm{Pt}$ a $600{ }^{\circ} \mathrm{C}$ com combustível $4 \% \mathrm{H}_{2}+96 \% \mathrm{~N}_{2}$.

As células com eletrólitos sólidos de zirconato de bário em todas as composições apresentaram um valor baixo de potência, comparado com valores relatados [81], apesar de atingir um potencial de $0,73 \mathrm{~V}$, esse sim compatível com os valores obtidos em SOFC de temperatura intermediária operando com metano. A potência da célula operando com hidrogênio foi menor do que operando com 
metano para a célula com eletrólito preparado em moinho atritor, provavelmente devido a problemas na selagem da célula. $O$ fluxo de metano necessário para atingir o potencial é muito baixo e conseqüentemente, a pressão é baixa e o tempo de residência do gás na câmara é alto, não necessitando de uma selagem perfeita. Já para o combustível $4 \% \mathrm{H}_{2}+96 \% \mathrm{~N}_{2}$, o fluxo é alto e com maior possibilidade de ocorrer vazamento do combustível.

\section{Célula LCFC/BaZr ${ }_{0,8} \mathrm{Y}_{0,2} \mathrm{O}_{3-\delta} / \mathrm{Pt}$}

\section{OCV - metano}

A Figura 42 mostra 0 potencial de circuito aberto da célula $\mathrm{LCFC} / \mathrm{BaZr}_{0,8} \mathrm{Y}_{0,2} \mathrm{O}_{3-\delta} / \mathrm{Pt}$ (eletrólito preparado utilizando moinho atritor) em função do tempo, na faixa de temperatura 300-600 ${ }^{\circ} \mathrm{C}$, com taxa de aquecimento 10 ○C/min e montadas utilizando a câmara de tijolo refratário.

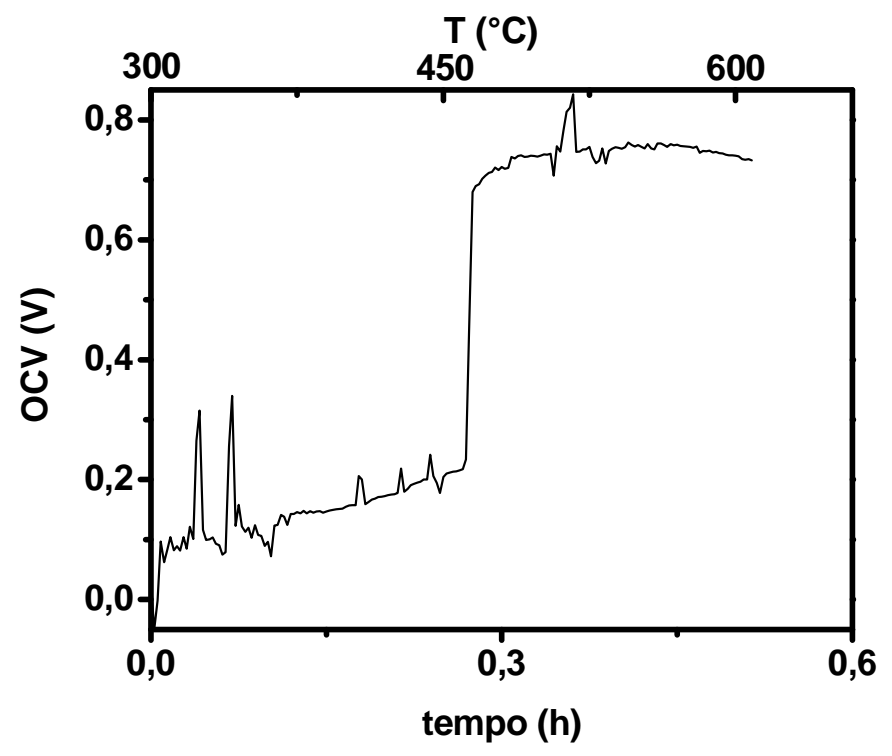

Figura 42: Potencial de circuito aberto da célula $L C F C / B a Z r_{0,8} \mathrm{Y}_{0,2} \mathrm{O}_{3-\delta} / \mathrm{Pt}$ (eletrólito sólido preparado por mistura de óxidos), operando com combustível metano de $300 \stackrel{\circ}{\mathrm{C}}$ a $600 \stackrel{\circ}{\circ} \mathrm{C}$.

O início da produção de hidrogênio se dá em $\sim 450^{\circ} \mathrm{C}(\mathrm{t}=0,25 \mathrm{~h})$. Há um salto no valor do potencial para $0,8 \mathrm{~V}$ em $\sim 515 \stackrel{\circ}{\circ} \mathrm{C}$ e a diminuição em $600{ }^{\circ} \mathrm{C}$, estabilizando em $0,73 \mathrm{~V}$. Esse comportamento foi observado na maioria das células testadas, principalmente quando era feita a programação inversa (600-300 
$\left.{ }^{\circ} \mathrm{C}\right)$. Quando resfriada, esta célula manteve constante o potencial de $0,79 \mathrm{~V}$ a 515 $\stackrel{\circ}{ } \mathrm{C}$.

\section{Curva IV - metano}

A Figura 43 mostra o valor do potencial em função da corrente da célula LCFC/BaZr $r_{0,8} \mathrm{Y}_{0,2} \mathrm{O}_{3-\delta} / \mathrm{Pt}$ com combustível metano a $600 \stackrel{\circ}{\circ} \mathrm{C}$.

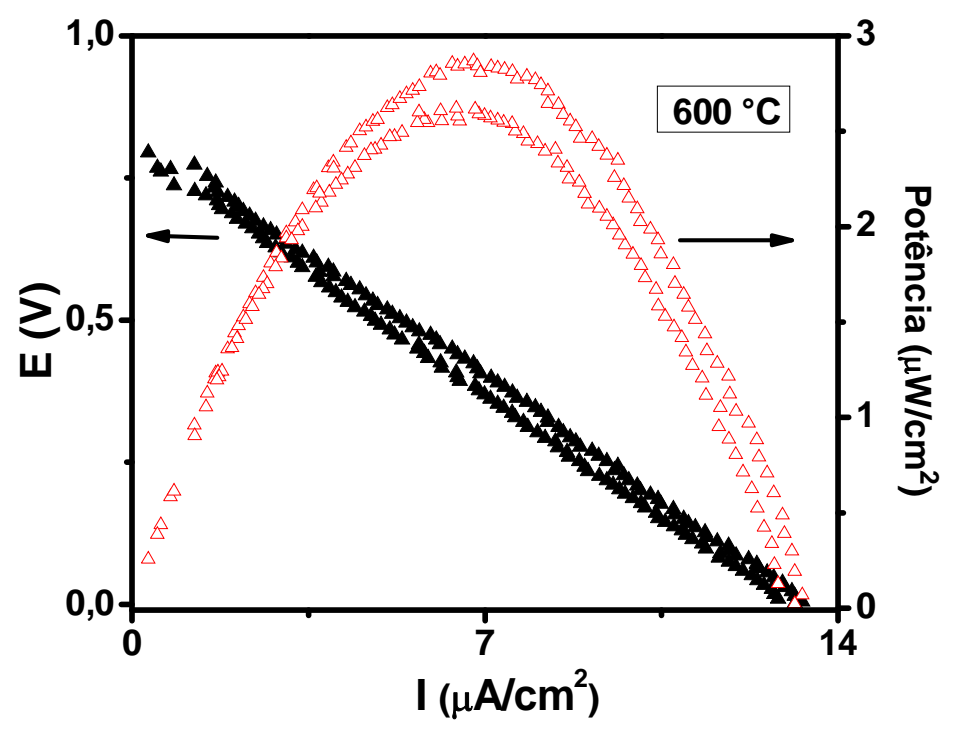

Figura 43: Potencial da célula LCFC/BaZr $r_{0,8} \mathrm{Y}_{0,2} \mathrm{O}_{3-\delta} / \mathrm{Pt}$ (eletrólito sólido preparado por mistura de óxidos) sob solicitação de carga a $600^{\circ} \mathrm{C}$, operando com metano.

Esta célula apresentou o melhor valor de potência dentre as composições de zirconato de bário com a configuração anodo de Pt/eletrólito/LCFC, e o mesmo comportamento (perda de potência) foi observado quando a temperatura de operação foi reduzida para $515 \stackrel{\circ}{\circ}$.

\section{Célula LCFC/BaZr ${ }_{0,85} \mathrm{Y}_{0,15} \mathrm{O}_{3-\delta} / \mathrm{Pt}$}

\section{OCV - metano}

A figura 44 mostra 0 potencial de circuito aberto da célula $\mathrm{LCFC} / \mathrm{BaZr}_{0,85} \mathrm{Y}_{0,15} \mathrm{O}_{3-\delta} / \mathrm{Pt}$ (eletrólito preparado por mistura de óxidos) em função do tempo na temperatura de $600{ }^{\circ} \mathrm{C}$. 


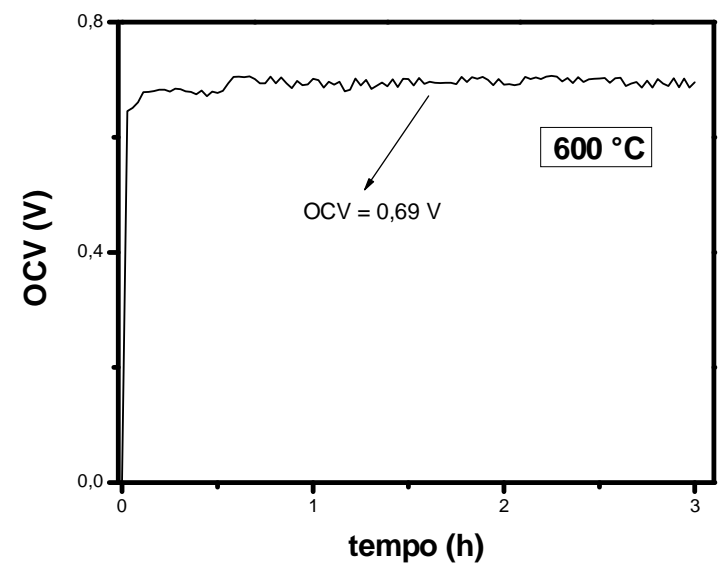

Figura 44: Potencial de circuito aberto da célula $\mathrm{LCFC} / \mathrm{BaZr}_{0,85} \mathrm{Y}_{0,15} \mathrm{O}_{3-\delta} / \mathrm{Pt}$ (eletrólito sólido preparado por mistura de óxidos) operando com combustível metano a $600 \stackrel{\circ}{\mathrm{C}}$.

O potencial desta célula não foi estável, variando de 0,67 a 0,7 V. Essa variação depende da montagem da célula, como por exemplo a homogeneidade na deposição do anodo e do catodo, a preparação do catodo e a formação de um eletrólito denso suficiente para impedir a passagem do gás e com alta condutividade protônica, além da montagem da célula no sistema de medidas (selagem, contatos elétricos e alimentação de combustível).

A figura 45 mostra 0 potencial de circuito aberto da célula $\mathrm{LCFC} / \mathrm{BaZr}_{0,85} \mathrm{Y}_{0,15} \mathrm{O}_{3-\delta} / \mathrm{Pt}$ (eletrólito preparado em moinho atritor) em função do tempo, na faixa de temperatura de $300{ }^{\circ} \mathrm{C}$ a $600{ }^{\circ} \mathrm{C}$ com taxa de aquecimento 10 ${ }^{\circ} \mathrm{C} /$ min. A figura 46 mostra o potencial de circuito aberto em função do tempo na temperatura de $600{ }^{\circ} \mathrm{C}$. 


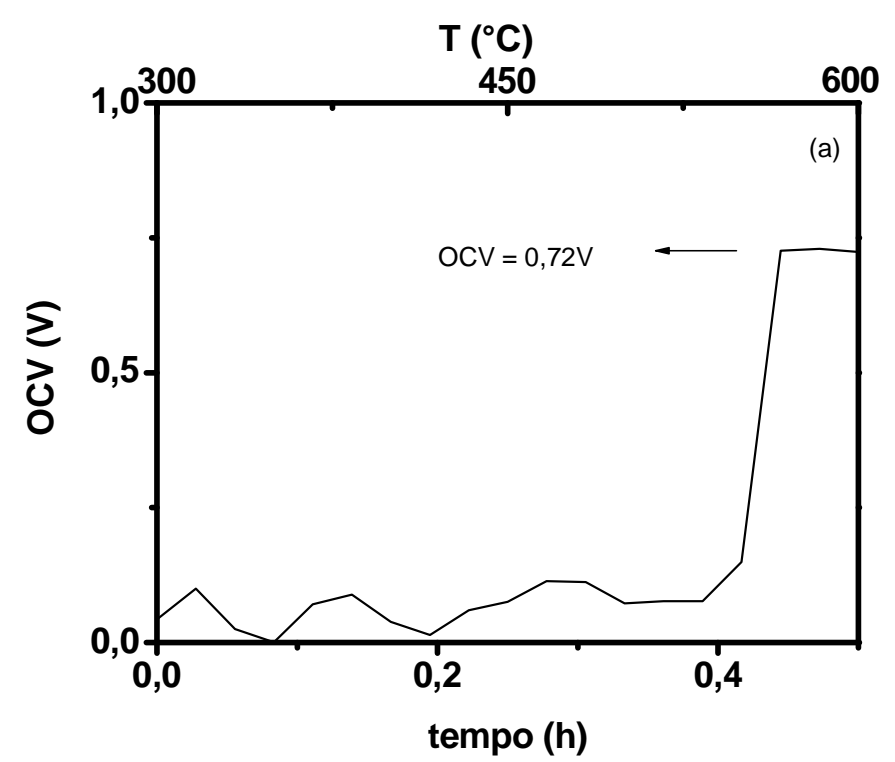

Figura 45: Potencial de circuito aberto em função do tempo de operação da célula $\mathrm{LCFC} / \mathrm{BaZr}_{0,85} \mathrm{Y}_{0,15} \mathrm{O}_{3-\delta} / \mathrm{Pt}$ na faixa de temperatura 300-600 ${ }^{\circ} \mathrm{C}$ operando com combustível metano.

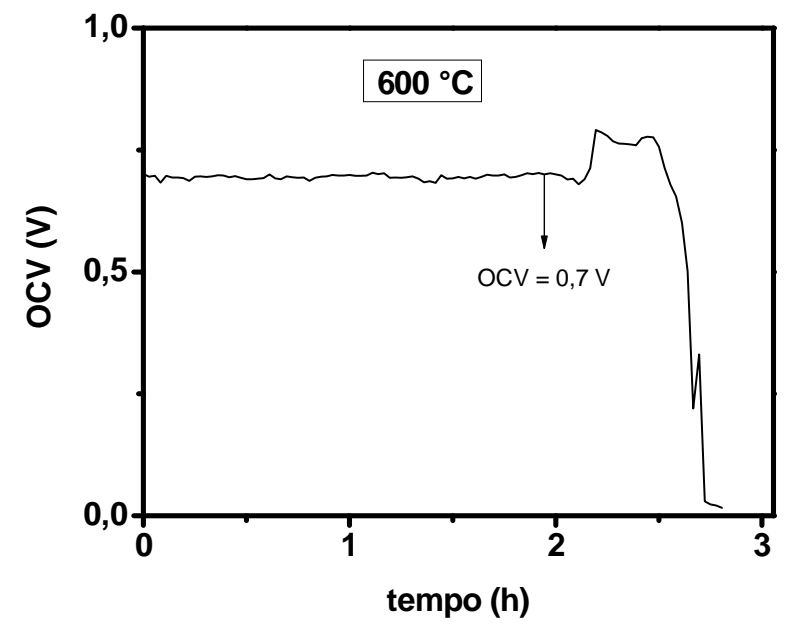

Figura 46: Potencial de circuito aberto em função do tempo de operação da célula $\mathrm{LCFC} / \mathrm{BaZr}_{0,85} \mathrm{Y}_{0,15} \mathrm{O}_{3-\delta} / \mathrm{Pt}$ a $600 \stackrel{\circ}{\circ}$ operando com combustível metano.

Estas células foram montadas com selante de vidro nióbio-fosfato, segundo o mesmo procedimento experimental descrito anteriormente, e apresentaram um potencial que variou de 0,70 a $0,72 \mathrm{~V}$ devido a ajustes no fluxo de combustível. É possível notar que ao final da operação da célula a $600 \stackrel{\circ}{\circ} \mathrm{o}$ potencial aumentou demonstrando a sensibilidade da célula em relação ao fluxo de combustível. 
A Figura 47 mostra o potencial de circuito aberto da célula $\mathrm{LCFC} / \mathrm{BaZr}_{0,85} \mathrm{Y}_{0,15} \mathrm{O}_{3-\delta} / \mathrm{Pt}$ em função do tempo, na faixa de temperatura de $300{ }^{\circ} \mathrm{C}$ a $600{ }^{\circ} \mathrm{C}$ com taxa de aquecimento $10^{\circ} \mathrm{C} / \mathrm{min}$, e o potencial de circuito aberto em função do tempo na temperatura de $600^{\circ} \mathrm{C}$, com um teste liga-desliga injeção de gás.

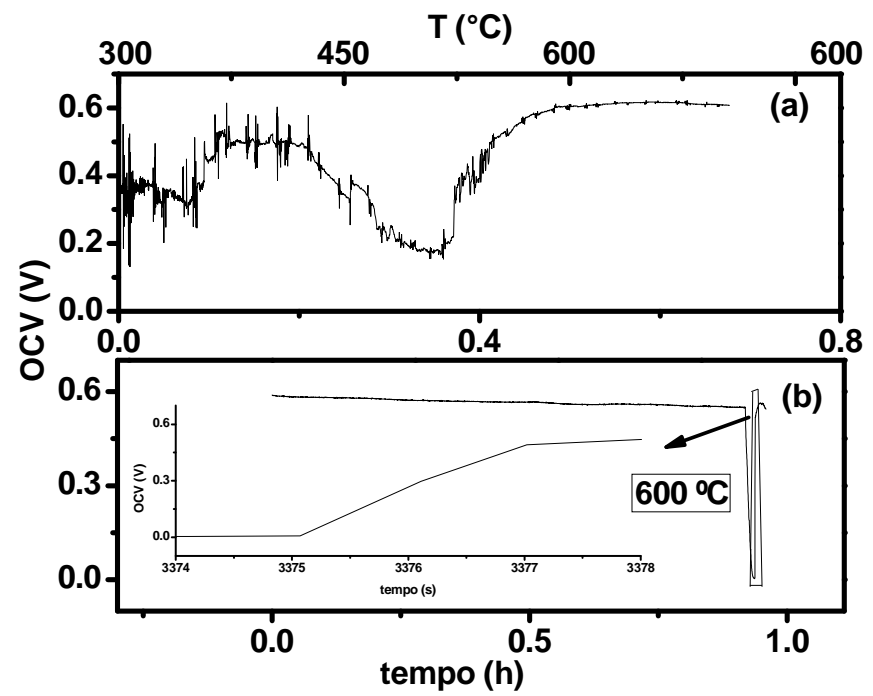

Figura 47: Potencial de circuito aberto da célula LCFC/BaZr ${ }_{0,85} \mathrm{Y}_{0,15} \mathrm{O}_{3-\delta} / \mathrm{Pt}$ de 300 ㄷ a $600{ }^{\circ} \mathrm{C}$ operando com metano (a) e operação contínua a $600 \stackrel{\circ}{\circ}$ com metano (b). A seta em (b) indica uma visão ampliada.

Há diminuição do ruído do sinal com o aumento da temperatura e o aumento do potencial, que ocorre por meio da produção de hidrogênio a partir do metano. Na Figura 47b é mostrada a queda do potencial devida à perda de pressão da válvula que injeta combustível, e a resposta rápida (2 s) do potencial no final com a injeção do metano; para esta célula foi usado o mesmo selante de vidro nióbio fosfato descrito anteriormente.

\section{OCV $-4 \% \mathrm{H}_{2}+96 \% \mathrm{~N}_{2}$}

A figura 48 mostra o potencial de circuito aberto da célula LCFC/BaZr ${ }_{0,85} \mathrm{Y}_{0,15} \mathrm{O}_{3-\delta} / \mathrm{Pt}$ em função do tempo na temperatura de $600{ }^{\circ} \mathrm{C}$. 


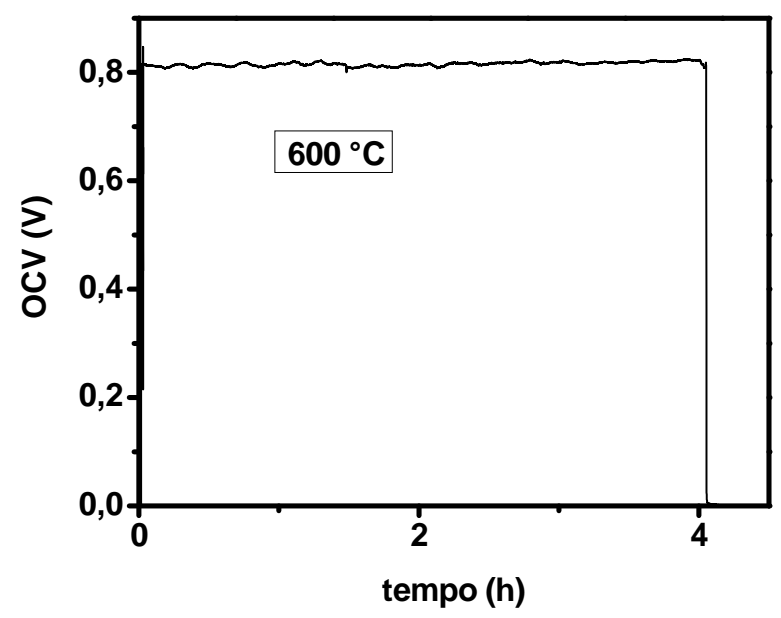

Figura 48: Potencial de circuito aberto da célula $\mathrm{LCFC} / \mathrm{BaZr}_{0,85} \mathrm{Y}_{0,15} \mathrm{O}_{3-\delta} / \mathrm{Pt}$ (eletrólito sólido preparado por mistura de óxidos) operando com combustível $4 \%$ $\mathrm{H}_{2}+96 \% \mathrm{~N}_{2}$ a $600 \stackrel{\circ}{\circ}$.

A célula mostrou um comportamento estável com o potencial de $0,81 \mathrm{~V}$ por mais de $4 \mathrm{~h}$.

A Figura 49 mostra 0 potencial de circuito aberto da célula $\mathrm{LCFC} / \mathrm{BaZr}_{0,85} \mathrm{Y}_{0,15} \mathrm{O}_{3-\delta} / \mathrm{Pt}$ em função do tempo a $600 \stackrel{\circ}{\circ} \mathrm{C}$.

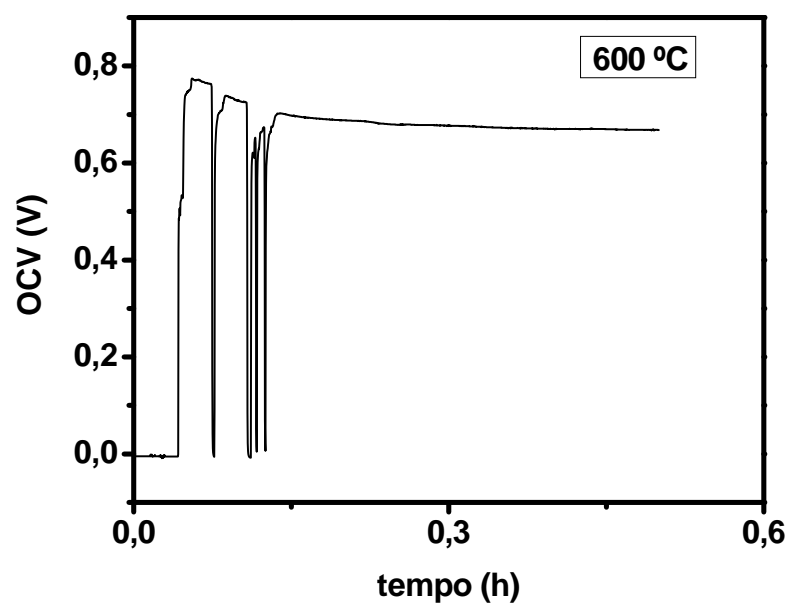

Figura 49: Potencial de circuito aberto da célula LCFC/BaZr $r_{0,85} \mathrm{Y}_{0,15} \mathrm{O}_{3-\delta} / \mathrm{Pt}$ com combustível $4 \% \mathrm{H}_{2}+96 \% \mathrm{~N}_{2}$ a $600 \stackrel{\circ}{\circ}$

O teste da célula a $600{ }^{\circ} \mathrm{C}$, com o ajuste do fluxo de gás, mostra a resposta rápida do potencial ao suprimento de combustível até o equilíbrio em 
$0,68 \mathrm{~V}$, com o potencial decaindo, provavelmente devido a vazamento de gás no selante ou através do próprio eletrólito sólido.

curvas IV - metano

A Figura 50 mostra o valor do potencial em função da corrente da célula LCFC/BaZr $0,85 \mathrm{Y}_{0,15} \mathrm{O}_{3-\delta} / \mathrm{Pt}$ com combustível metano a $600{ }^{\circ} \mathrm{C}$.

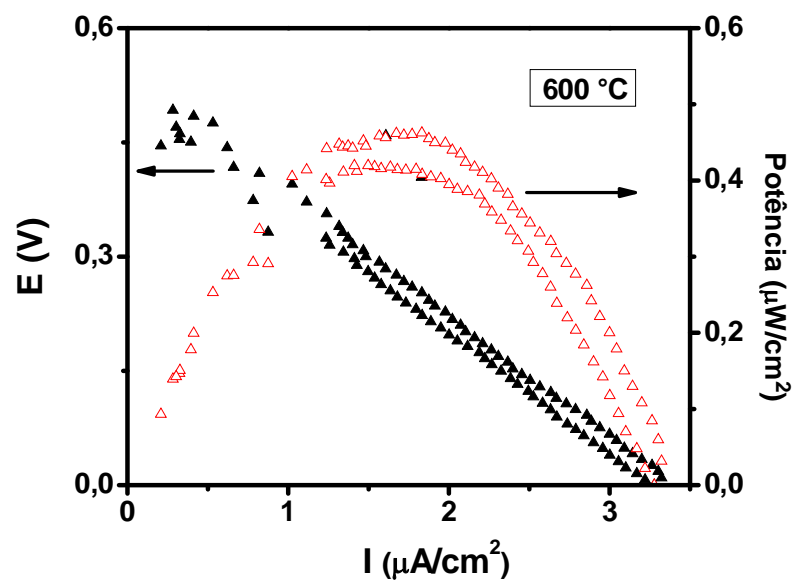

Figura 50: Potencial sob solicitação de carga da célula $L C F C / B a Z r_{0,85} Y_{0,15} \mathrm{O}_{3-\delta} / \mathrm{Pt}$ a $600{ }^{\circ} \mathrm{C}$ com combustível metano.

A potência da célula é relativamente baixa com processos de cargadescarga, que ocorrem no início da aplicação de corrente.

A figura 51 mostra uma micrografia da interface eletrólito/selante de vidro em uma das células. 


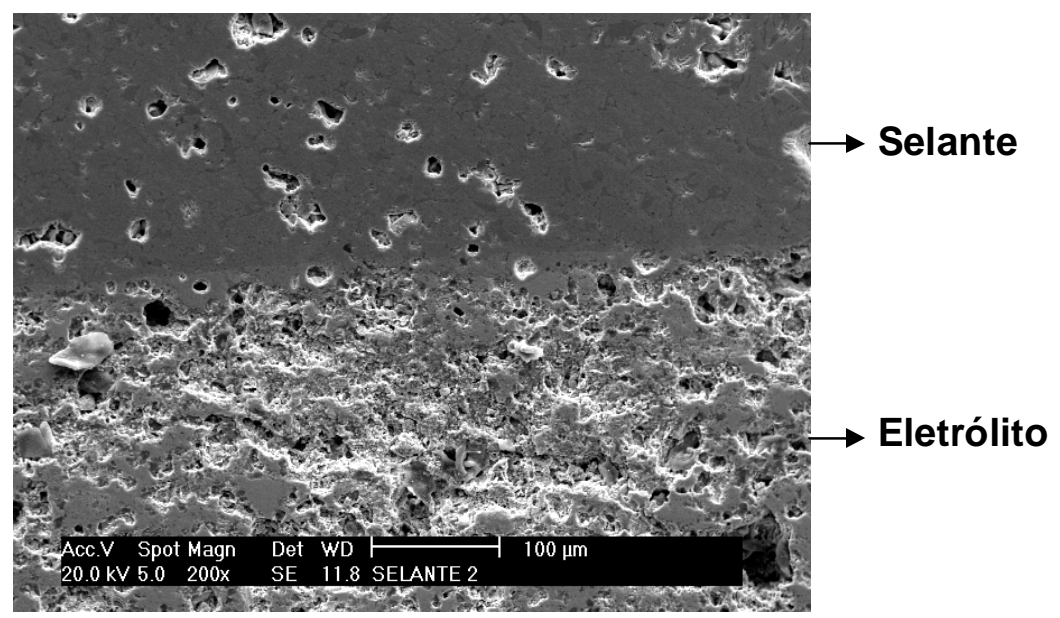

Figura 51: Micrografia obtida por microscopia eletrônica de varredura de uma secção transversal selante/eletrólito $\mathrm{BaZr}_{0,85} \mathrm{Y}_{0,15} \mathrm{O}_{3-\delta}$.

Fica evidente a alta densificação do selante de vidro e a relativamente elevada porosidade relativa do $\mathrm{BaZr}_{0,85} \mathrm{Y}_{0,15} \mathrm{O}_{3-\delta}$.

\section{Espectroscopia de impedância}

A figura 52 apresenta os diagramas de impedância das células montadas com eletrólito sólido de zirconato de bário sinterizados a $1500{ }^{\circ} \mathrm{C}$ e medidas a $600 \mathrm{C}$.

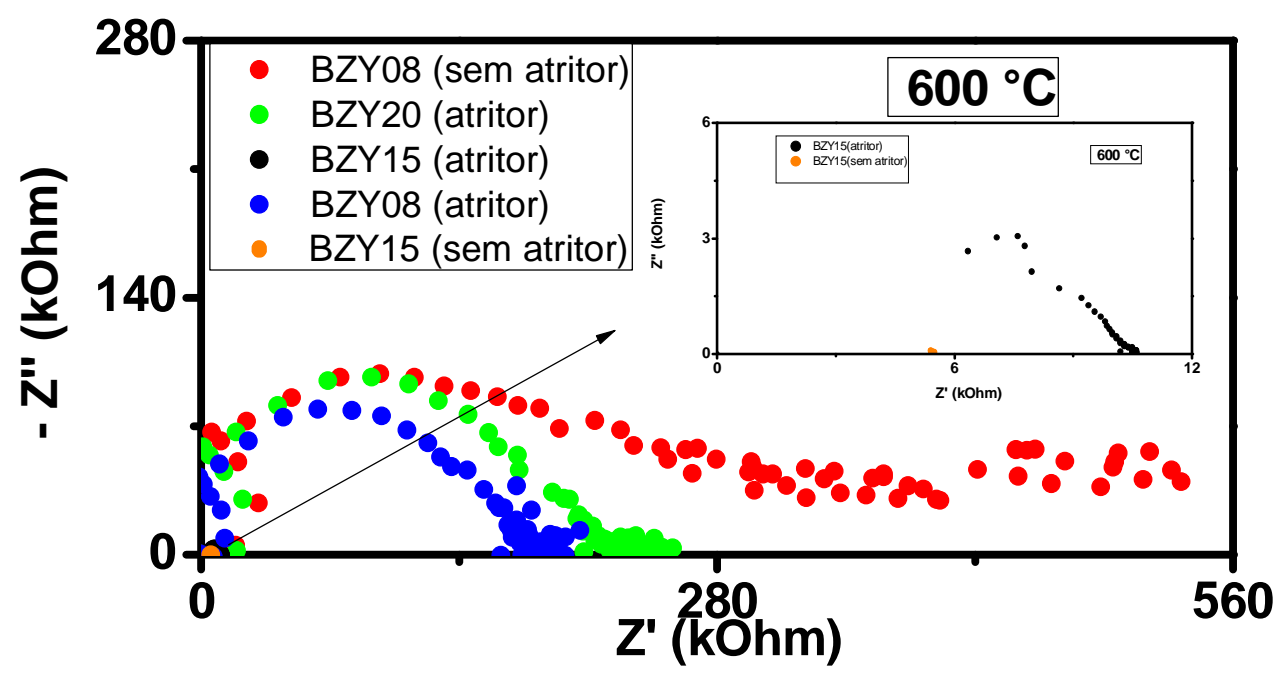


Figura 52: Diagramas de impedância das células a combustível na configuração LCFC/zirconato de bário/Pt com eletrólitos sólidos de várias composições, medidos a $600{ }^{\circ} \mathrm{C}$.

Os menores valores de resistividade indicam que o eletrólito sólido preparado com pós cominuídos em moinho atritor foram eficiente para as células LCFC/BaZr ${ }_{0,92} \mathrm{Y}_{0,08} \mathrm{O}_{3-\delta} / \mathrm{Pt}$, que mostraram semicírculos deformados; para as células $\mathrm{LCFC} / \mathrm{BaZr}_{0,85} \mathrm{Y}_{0,15} \mathrm{O}_{3-\delta} / \mathrm{Pt}$, a resistividade foi menor para o eletrólito sólido preparado por mistura de óxidos. 


\section{Conclusões}

As células a combustível com eletrólitos sólidos de zirconato de bário apresentaram, operando com metano a $600^{\circ} \mathrm{C}$, um potencial de circuito aberto similar aos obtidos nas células com eletrólitos sólidos de cerato de bário, tanto na configuração com anodo e catodo de $\mathrm{Pt}$ quanto na configuração com $\mathrm{La}_{0,6} \mathrm{Ca}_{0,4} \mathrm{Fe}_{0,8} \mathrm{Co}_{0,2} \mathrm{O}_{3-\delta}$ no catodo e Pt no anodo. Entretanto, nos testes com $4 \% \mathrm{H}_{2}$ + $96 \% \mathrm{~N}_{2}$, as células com eletrólitos sólidos de cerato de bário dopado com gadolínio $\left(\mathrm{BaCe}_{0,8} \mathrm{Gd}_{0,2} \mathrm{O}_{3-\delta}\right)$ apresentaram melhores valores de potencial de circuito aberto com ambas configurações.

O uso de moinho atritor na preparação de eletrólitos sólidos não promoveu a melhoria nas células eletroquímicas, aferindo-se os potenciais de circuito aberto e de potência das células.

As células a combustível mostraram uma maior estabilidade do sinal elétrico quando operadas sob baixo fluxo de metano a $600^{\circ} \mathrm{C}$, mostrando que com esse combustível não é necessária uma selagem perfeita e alta densificação porque na pressão de operação não há difusão do combustível através do eletrólito sólido.

Entre as duas configurações da célula com $\mathrm{BaCeGdO}_{3}$, a que apresentou os melhores valores de potência a $600{ }^{\circ} \mathrm{C}$, operando sob metano e sob $4 \% \mathrm{H}_{2}+$ $96 \% \mathrm{~N}_{2}$, foi a célula com eletrodos de Pt. Para a célula com $\mathrm{BaZrYO}_{3}$, os resultados com metano indicam que a configuração $\mathrm{LCFC} / \mathrm{BaZr}_{0,8} \mathrm{Y}_{0,2} \mathrm{O}_{3-\delta} / \mathrm{Pt}$ apresenta melhores resultados.

Nas configurações LCFC/BaCe $0{ }_{0,8} \mathrm{Gd}_{0,2} \mathrm{O}_{3-\delta} / \mathrm{Pt}$ e LCFC/BaZr $\mathrm{L}_{0,92} \mathrm{Y}_{0,08} \mathrm{O}_{3-\delta} / \mathrm{Pt}$, os resultados de potência operando a $600^{\circ} \mathrm{C}$ sob metano e sob $4 \% \mathrm{H}_{2}+96 \% \mathrm{~N}_{2}$ foram melhores na célula com $\mathrm{BaCe}_{0,8} \mathrm{Gd}_{0,2} \mathrm{O}_{3-\delta}$.

As células com eletrólito zirconato de bário na configuração LCFC/BaZr ${ }_{0,85} \mathrm{Y}_{0,15} \mathrm{O}_{3-\delta} / \mathrm{Pt}$ apresentaram os menores valores de resistividade elétrica a $600^{\circ} \mathrm{C}$. 


\section{Referências}

[1] M. Oliveira, Reforma Energética, Revista Pesquisa FAPESP, SP, 126 (2006) 6773.

[2] W. Vielstich, A. Lamm, H. A. Gasteiger, "Handbook of Fuel Cells Fundamentals, Technology and Applications", vol.1, John Wiley \& Sons Ltd., Inglaterra (2003).

[3] H. Wendt, M. Götz, e M. Linardi, Química Nova 23 (2000) 4.

[4] A. J. Appleby, F. R. Foulkes, "Fuel Cell Handbook", Van Nostrand Reinhold, New York, EUA (1989).

[5] E. A. Ticianelli, G. A. Câmara, L. G. R. A. Santos, Química Nova 28, 4 (2005) 664.

[6] L. S. Akira Kaimoto, E. F. Leite e M. G. Coelho, "Considerações sobre aproveitamento do Biogás em Aterro Sanitário"(2006).

[7] M. Duerr, S. Gair, A. Cruden, J. McDonald, Int. J. Hydrogen Energy 32 (2007) 705-709.

[8] N. Vasconcelos, "Reforma a vapor do metano em catalisadores à base de níquel promovidos com nióbia", Diss. Mestrado (2006).

[9] N. Q. Minh, J. Am. Ceram. Soc. 76 (1993) 563.

[10] T. Hibino, S. Q. Wang, S. Kakimoto, M. Sano, Electrochem. Solid State Lett. 2 (1999) 317.

[11] T. Hibino, Y. Kuwahara, S. Wang, J. Electrochem. Soc. 146 (1999) 2821.

[12] T. Hibino, S. Wang, S. Kakimoto, M. Sano, Solid State lonics 127 (2000) 89.

[13] T. Hibino, H. Tsunekawa, S. Tanimoto, M. Sano, J. Electrochem. Soc. 147 (2000) 1338.

[14] T. Hibino, S. Hashimoto, T. Inoue, J. Tokuno, S. Yoshida, M. Sano, J. Electrochem. Soc. 147 (2000) 2888.

[15] T. Hibino, A. Hashimoto, T. Inoue, J. Tokuno, S. Yoshida, M. Sano, Science 288 (2000) 2031.

[16] T. Hibino, A. Hashimoto, M. Suzuki, M. Yano, S. Yoshida, M. Sano, J. Electrochem. Soc.149 (2002) 195.

[17] T. W. Napporn, F. Morin, M. Meunier, Electrochem. Solid State Lett. 7 (2004) 60.

[18] I. C. Stefan, C. P. Jacobson, S. J. Visco, L. C. De Jonghe, Electrochem. Solid State Lett. 7 (2004) 198. 
[19] T. Suzuki, P. Jasinki, H. U. Anderson, F. Dogan, J. Electrochem. Soc. 151 (2004) 1678.

[20] A. Tomita, D. Hirabayashi, T. Hibino, M. Nagao, M. Sano, Electrochem. Solid State Lett. 8 (2005) 63.

[21] T. Suzuki, P. Jasinki, V. Petrovsky, H. U. Anderson, F. Dogan, J. Electrochem. Soc. 152 (2005) 527.

[22] Z. P. Shao, S. M. Haile, Nature 431 (2004) 170.

[23] T. Norby, Solid State lonics 125 (1999) 1.

[24] L. Zhang, S. P. Jiang, W. Wang, Y. J. Zhang, J. Power Sources 170 (2007) 55.

[25] B. Zhu, X. R. Liu, T. Schober, Electrochem. Comm. 6 (2004) 378.

[26] C. D. Zuo, S. W. Zha, M. L. Liu, M. Hatano, M. Uchiyama, Adv. Mater. 18 (2006) 3318.

[27] J. X.Wang, W. H. Su, D. P. Xu, T. M. He, J. Alloys Compd. 421 (2006) 45.

[28] T. Hibino, A. Hashimoto, M. Suzuki, M. Sano, J. Electrochem. Soc. 149 (2002) A1503.

[29] K. Eguchi, T. Setoguchi, T. Inoue, H. Arai, Solid State lonics 52 (1992) 165.

[30] B. C. H. Steele, Solid State lonics 129 (2000) 95.

[31] M. Mogensen, D. Lybye, N. Bonanos, P.V. Hendriksen, F.W. Poulsen, Solid State lonics 174 (2004) 279-286.

[32] C. Milliken, S. Guruswamy, J. Am. Ceram. Soc. 85 (2002) 2479.

[33] A. Atkinson, T. M. G. M. Ramos, Solid State lonics 129 (2000) 259.

[34] D. Z. de Florio, F. C. Fonseca, E. N. S. Muccillo, R. Muccillo, Cerâmica 50 (2004) 275-290.

[35] S. M. Haile, Acta Materialia 51 (2003) 5981-6000.

[36] H. Matsumoto, T. Shimura, H. Iwahara, H. Hiroyasu, T. Higushi, K. Yashiro, K. A. Kaimai, T. Kawada, J. Mizusaki, J. Alloys Compd 408 (2006) 456-462.

[37] T. Schober, W. Coors, W. Grover, Solid State lonics 176 (2005) 357.

[38] K. D. Kreuer, Chem. Mater. 8 (1996) 610.

[39] H. Iwahara H, T. Yajima, T. Hibino, H. Ushida, J. Electrochem. Soc. 140 (1993) 1687.

[40] S. M. Haile, G. Staneff, K. H. Ryu. J. Mater. Sci 36 (2001) 1149.

[41] K. D. Kreuer, Solid State Ionics 125 (1999) 285.

[42] H. G. Bohn, T. Schober, J. Am. Ceram. Soc. 83 (2000) 768.

[43] N. Taniguchi, E. Yasumoto, T. Gamo, J. Electrochem. Soc. 143 (1996) 1186. 
[44] http://www.celulaacombustivel.com.br

[45] M. J. Scholten, J. Schoonman, J. C. van Miltenburgh, H. A. J. Oonk, Solid State lonics 61 (1993) 83.

[46] R. C. T. Slade, S. D. Flint, N. Singh, Solid State lonics 82 (1995) 135.

[47] H. Iwahara, T. Yajima, T. Hibino, K. Ozaki and H. Suzuki, Solid State lonics 61 (1993) 65.

[48] T. Norby, Solid State lonics 125 (1999) 1.

[49] K. Katahira, Y. Kohchi, T. Shimura, H. Iwahara, Solid State lonics 138 (2000) 91.

[50] K. H. Ryu and S. M. Haile, Solid State lonics 123 (1999) 355.

[51] S. Wienstroer, H.-D. Wiemhofer, Solid State lonics 1113 (1997)101.

[52] K. D. Kreuer, St. Adams, W. Munch, A. Fuchs, U. Klock, J. Maier, Solid State lonics 145 (2001) 295.

[53] A. M. Azad, S. Subramaniam, T. W. Dung, J. Alloys Compd. 334 (2002) 118.

[54] A. Erb, E. Walker, R. Flukiger, Physica C 245 (1995) 245.

[55] Z.Chen, S. Duncan, K. K. Chawla, M. Koopman, G. M. Janowski, Mater. Charact. 48 (2002) 305.

[56] M. Viviani, M. T. Buscaglia, V. Buscaglia, M. Leoni, P. Nanni, J. Eur. Ceram. Soc. 21 (2001) 1981.

[57] A. Manthiram, J. K. Kuo, J. B. Goodenough, Solid State lonics 62 (1993) 225.

[58] S. M. Haile, Mater. Today 6 (2003) 24.

[59] M. Bucko, J. Oblakowski, J. Eur. Ceram. Soc. 27 (2007) 3625.

[60] N. Yamazoe, Y. Shimizu, Sens. Actuators B 10 (1986) 379.

[61] B. M. Kulwicki, J. Am. Ceram. Soc. 74 (1991) 697.

[62] E. Traversa, Sens. Actuators B 23 (1995) 135.

[63] P. Shuk, M. Greenblatt, Solid State lonics 113-115 (1998) 229.

[64] X. Shi, Q. Chen, J. Fang, K. Varahramyan, H. Ji, Sens. Actuators B 129 (2008) 225.

[65] G. Di Francia, A. Castaldo, E. Masserra, I. Nasti, L. Quercia, I. Rea, Sens. Actuators B 111-112 (2005) 135.

[66] K. Arshaka, K. Twomey, D. Egan, Sensors 2 (2002) 50.

[67] Y. Sakai, Y. Sadaoka, M. Matsuguchi, Sens. Actuators B 35-36 (1996) 85.

[68] K. D. Kreuer, Ann. Rev. Mater. Res. 33 (2003) 333. 
[69] J. T. S. Irvine, S. W. Tao, C. D. Savaniu, A. Kruth, British Patent Application, N. 0406818.5; European Patent Application N. 03766465.3, 2004.

[70] S. W. Tao, J. T. S. Irvine, Adv. Mater. 18 (2006) 1581.

[71] P. Babilo, S. M. Haile, J. Am. Ceram. Soc. 88 (2005) 2362.

[72] H. Iwahara, Y. Asakura, K. Katahira, M. Tanaka, Solid State lonics 168 (2004) 299.

[73] W. G. Coors, J. Electrochem. Soc. 151 (2004) A994.

[74] F. Lefebvre-Joud, G. Gauthier, J. Mougin, J. Appl. Electrochem. 39 (2009) 535.

[75] C. Suryanarayana, Progr. Mater. Sci. 46 (2001) 18.

[76] I. R. Oliveira, A. R. Studart, M. D. M. Innocentini, L. A. Nascimento, V. C. Pandolfelli, Cerâmica 50, 313 (2004) 1.

[77] J. R. Martinelli, A. Rogério, F. C. Fonseca, E. N. S. Muccillo, D. Z. de Florio, O. R. Oliveira, R. Muccillo (2008) a ser publicado.

[78] W. Ruland, Acta Cryst. 18 (1965) 581.

[79] A. J. C. Wilson, J. Sci. Inst. 27 (1950) 321.

[80] B. C. H. Steele, Phil. Trans. Royal Soc. London A - Math. Phys. \& Eng. Sci. 354, 1712 (1996) 1695.

[81] loannis V. Yentekakis, J. Power Sources 160 (2006) 422. 